MARIA BETÂNIA SILVEIRA

\title{
TECER O BARRO: \\ Uma Construção de Percursos e Conexões da Cerâmica em Hipermídia.
}

Dissertação apresentada ao Programa de Pós-Graduação em Artes, Área de concentração Artes Plásticas, Linha de Pesquisa Poéticas Visuais, da Escola de Comunicações e Artes da Universidade de São Paulo, como exigência parcial para obtenção do Título de Mestre em Artes, sob a orientação da Prof ${ }^{a}$. Dr ${ }^{\text {a. }}$ Norma Tenenholz Grinberg.

São Paulo

2006 
This document was created with Win2PDF available at http://www.daneprairie.com. The unregistered version of Win2PDF is for evaluation or non-commercial use only. 
MARIA BETÂNIA SILVEIRA

\section{TECER O BARRO: \\ Uma Construção de Percursos e Conexões da Cerâmica em Hipermídia.}

Dissertação apresentada ao Programa de Pós-Graduação em Artes, Área de concentração Artes Plásticas, Linha de Pesquisa Poéticas Visuais, da Escola de Comunicações e Artes da Universidade de São Paulo, como exigência parcial para obtenção do Título de Mestre em Artes, sob a orientação da Prof ${ }^{a}$. Dr ${ }^{\text {a. }}$ Norma Tenenholz Grinberg.

São Paulo

2006 
S587t Silveira, Maria Betânia

Tecer o barro : uma construção de percursos e conexões da cerâmica em hipermídia / Maria Betânia Silveira; orientadora Norma Tenenholz Grinberg. - São Paulo, 2006.

XII, 68 p. : fotos + 1 CD-ROM.

Dissertação (Mestrado) - Universidade de São Paulo, Escola de Comunicações e Artes, Programa de Pós-Graduação em Artes, 2006.

Inclui bibliografia.

1.Cerâmica - Arte. 2. Cerâmica - Multimídia interativa. I. Grinberg, Norma Tenenholz. II. Universidade de São Paulo. Escola de Comunicações e Artes. Programa de Pós-Graduação em Artes. III. Título.

CDU: 738

Catalogação na fonte por: Heloísa Helena Caminha Bradacz CRB-14/236 


\title{
Maria Betânia Silveira
}

\section{TECER O BARRO: Uma Construção de Percursos e Conexões da Cerâmica em Hipermídia}

Esta dissertação foi julgada adequada para a obtenção do título de Mestre em Artes e aprovada em sua forma final pelo programa de Pós-Graduação em Artes, área de concentração Artes Plásticas, linha de pesquisa Poéticas Visuais da Escola de Comunicações e Artes de São Paulo.

\section{Professora Dra. Norma Tenenholz Grinberg}

Banca examinadora:

\author{
Professora Dra. Norma Tenenholz Grinberg \\ Orientadora
}

Professor Dr. João Evangelista Barbosa Romeu da Silveira 
Um galo sozinho não tece uma manhã: ele precisará sempre de outros galos. De um que apanhe esse grito e que ele o lance a outro; de um outro galo antes e o lance a outro, e de outros galos que com muitos outros galos se cruzem os fios de sol de seus gritos de galo, para que a manhã desde uma teia tênue, se vá tecendo, entre todos os galos (...). (JOÃO CABRAL DE MELO NETO) 


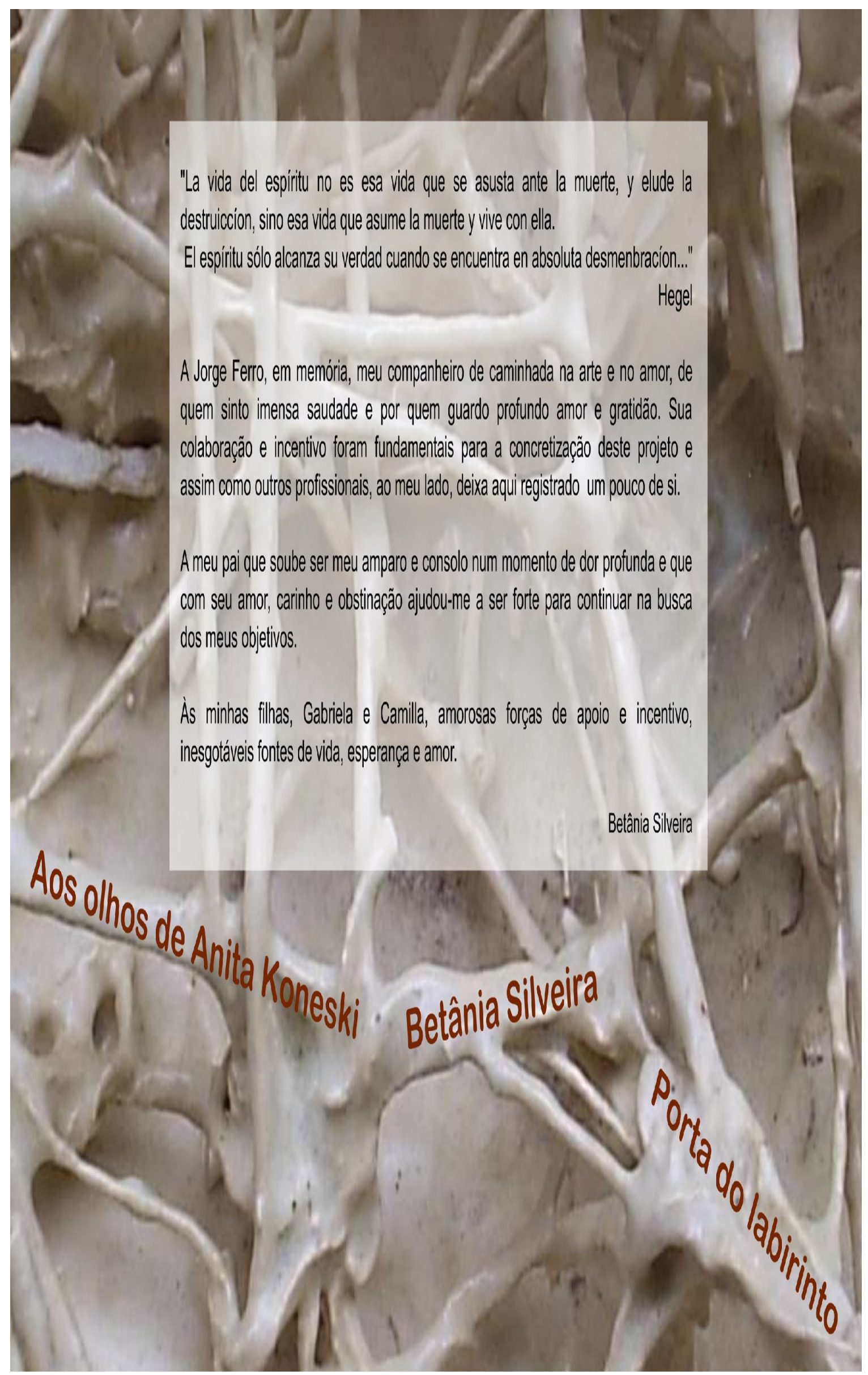


Trata-se, de fato, de uma amarração ou de uma implicação recíproca porque não somos corpos limitados por uma bolsa de pele, nem imagens sociais, mas fluxos de

experiência, de vulneráveis sensibilidades, corações, almas, consciências; porque as consciências estão inteiramente abertas para um mundo único e comum no qual as intenções, os pensamentos, as emoções e os atos de uns fazem parte da experiência dos outros, contêm-se e condicionam-se mutuamente. Eis o fundamento do amor universal.

(PIERRE LEVY)

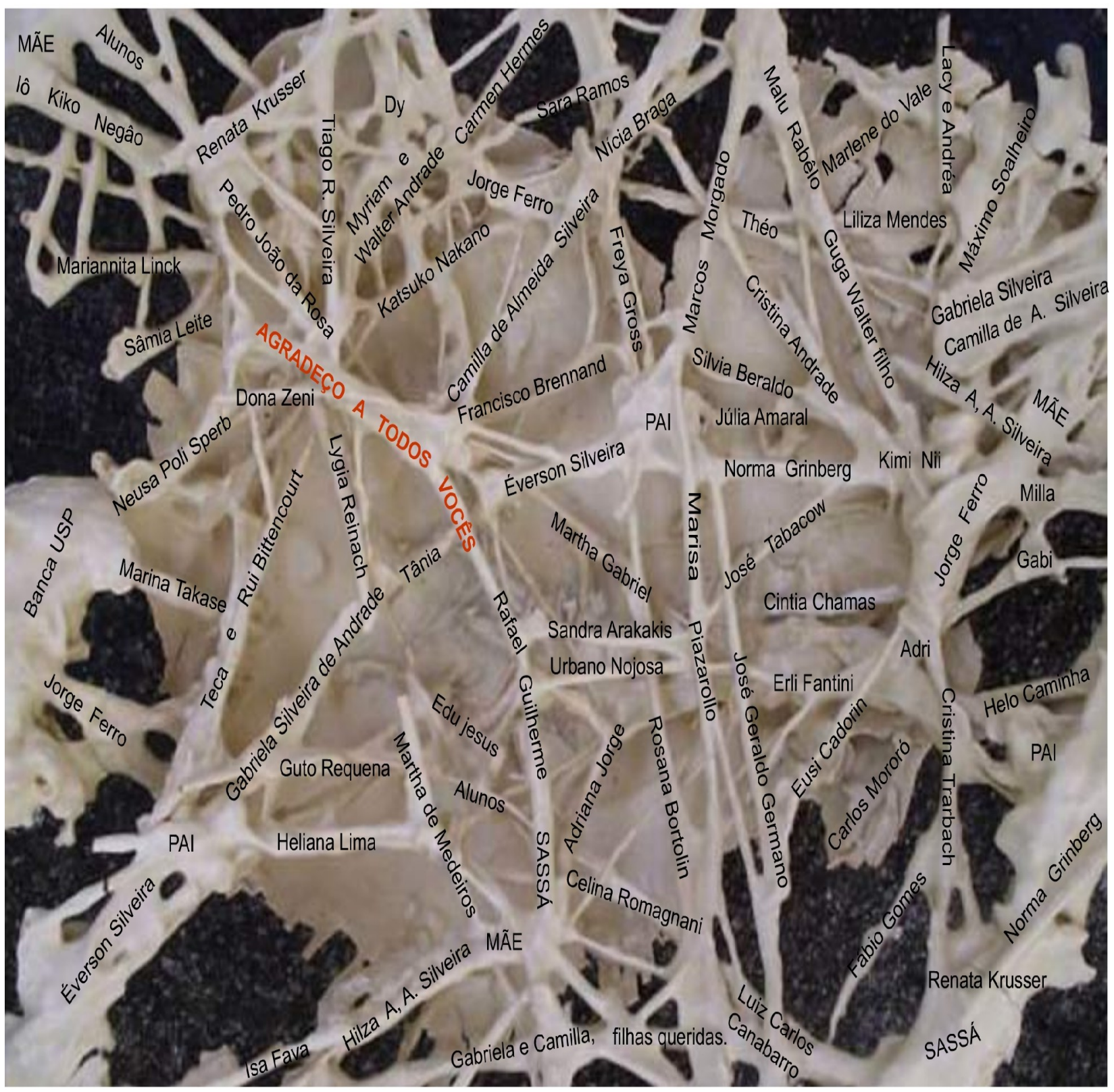

Sem a amizade, o mundo é um deserto. (FRANCIS BACON) 
SILVEIRA, Maria Betânia. Tecer o Barro: uma construção de percursos e conexões da cerâmica em hipermídia. São Paulo, 2006. 68p. Dissertação (Mestrado em Artes Plásticas) - Universidade de São Paulo.

\section{RESUMO}

Esta dissertação associa a cerâmica às novas tecnologias do computador objetivando a criação de um $C D-R O M$ híbrido. Trabalho que se realiza na construção de uma grande rede tramada com a poética da terra, dos devaneios da matéria, da massa e do fogo, do laborioso jogo do fazer com as mãos, com a poética do virtual, da extensão do corpo, do caminho labiríntico que se desdobra em muitas possibilidades no instante de um clicar eletrônico.

Ao longo do desenvolvimento deste $C D-R O M$, imagens poéticas estarão entrelaçadas às informações e conhecimento científico sobre o assunto.

A partir do conceito de trama é desenvolvida, com registros fotográficos e em vídeos, uma pesquisa pessoal com o material cerâmico em ateliê. Imagens destes trabalhos são utilizadas ao longo da construção do objeto $C D-R O M$ assim como a de outras produções.

Neste CD apresentam-se alguns profissionais brasileiros, que utilizam a cerâmica como suporte para sua expressão plástica, seus trabalhos, além de diversas técnicas e processos deste fazer.

Todo o conteúdo informativo poderá ser acessado e enriquecido através da interatividade possibilitada pela hipermídia. Trata-se, portanto, de um trabalho que enfoca o individual e o coletivo.

Utilizou-se para este desenvolvimento conceitos da área da comunicação e informática, tais como multimídia, hipermídia, hipertexto, interatividade, labirinto e rizoma, entre outros. 
Palavras chaves: Cerâmica, hipermídia, interatividade, labirinto e rizoma. 
SILVEIRA, Maria Betânia. Tecer o Barro: a cronstruccion of views and conections of the ceramic in hypermedia. São Paulo, 2006. 68p. Dissertation (Master in Visual Poetics) - University of São Paulo.

\section{ABSTRACT}

This issues associated with ceramic to the new technologies of computer and its goals on the creation of a hybrid $C D-R O M$. This work takes place in the construction of a great net schemed with the poetic of the earth, of the fantasy of the matter, of the mass and of the fire, the laborious game of doing with hands, with poetic of the virtual, of the extension of the body, of the labyrinth road that is unfolded in a lot of possibility in the moment of electronic clicks.

Along the development of this $C D-R O M$, poetic of images will be interlaced to the information and scientific knowledge on the subject.

It starts from the plot concept and it is developed with photographic registration and video, also with a personal research with the ceramic material in atelier. Image of these works have been used along the construction of this $C D-R O M$, as well as one of another productions. In this $C D$ there are some Brazilians professionals that use the ceramic as support for its plastic expression in their works, besides several techniques and processes of this.

The whole informative content can be accessed and enriched, through the integrate possibility for the hypermedia. It is, therefore, a work that focuses the individual and the collectively. It was used for this development several concepts of the area of the communication and computer science as multimedia, hypermedia, hypertext, interactive, labyrinth and rhizome among others.

Key Words: Ceramic, hypermedia, interactive, labyrinth and rhizome. 


\section{SUMÁRIO}

INTRODUÇÃO

2 A CERÂMICA EM HIPERMIDIA: O SENTIDO DE ASSIM "TECER

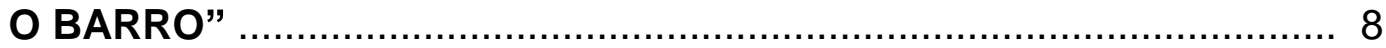

3 PROCEDIMENTOS METODOLÓGICOS ….................................... 16

4 ENTRELAÇADOS, UMA POÉTICA QUE SE CORPORIFICA EM

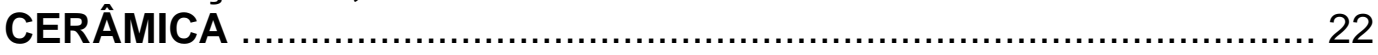

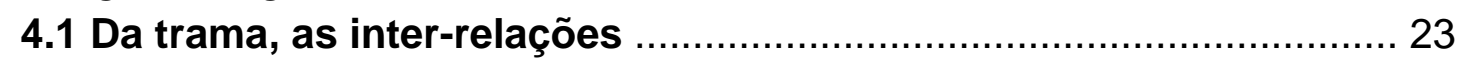

4.2 Das inter-relações, o percurso ................................................... 24

4.3 Tramando com fios de barro: pesquisa e processo ..................... 32

5 A CONSTRUÇÃO DO DVD COMO ENTRETECIDO DE POÉTICA

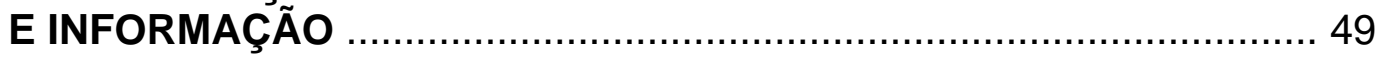

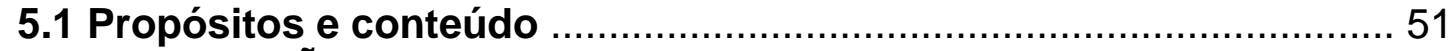

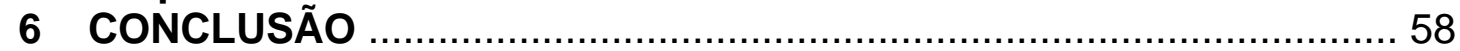

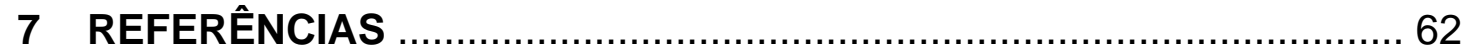

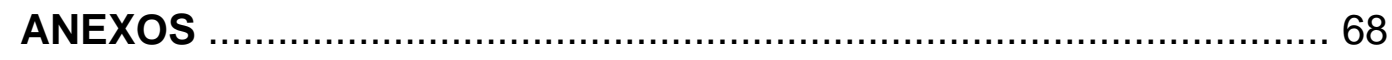




\section{ÍNDICE DE FIGURAS}

Figura 1. - Três tópicos e suas subdivisões, indicando a construção da trama..... 20

Figura 2 - Três tópicos e suas subdivisões, indicando a construção da trama.......20

Figura 3. - Três tópicos e suas subdivisões, indicando a construção da trama..... 21

Figura 4 - DIAPHANA. Galeria das Oficinas de Arte do MASC/CIC Fpolis,

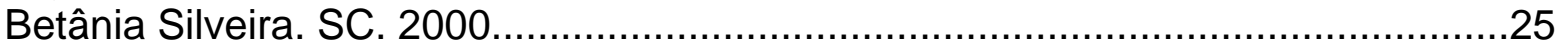

Figura 5 - DIAPHANA - Ação no ônibus. Betânia Silveira, Florianópolis-2002........26

Figura 6 - DIAPHANA - Ação no ônibus. Betânia Silveira, Florianópolis-2002........26

Figura 7 - DIAPHANA. Intervenção urbana, dunas da Lagoa da Conceição.

Betânia Silveira. Florianópolis, 2004............................................................27

Figura 8 - DIAPHANA. Intervenção urbana, na praça do teatro de Manaus.

Betânia Silveira. Janeiro, 2005.................................................................28

Figura 9 - Detalhe: imagem usada em projeto para sala expositiva....................28

Figura 10 - "Continuum" - Projeto instalação. Dimensões: $3 m$ x 1,30m x 1,50m.

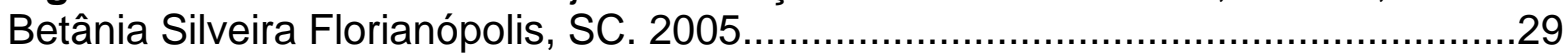

Figura 11 - Fotografia plotada em lona. Betânia Silveira. 2005............................29

Figura 12 - Telúricas. Cerâmica (massas coloridas e com metal).

Betânia Silveira, 2001..............................................................................

Figura 13 - Cerâmica Digital. Objeto interativo.Betânia Silveira, 2003/2004...........31

Figura 14 - Detalhe Objeto, Cerâmica Digital...............................................

Figura 15 - Cordão fino de algodão sobre placa de gesso.

Betânia Silveira, São Paulo, 2004...............................................................35

Figura 16 - Cordão fino de algodão sobre placa de gesso associada a forma

convexa. Vista lateral do objeto anterior...........................................................36

Figura 17 - Cordão grosso de algodão sobre placa cindida com forma convexa.

Betânia Silveira, São Paulo, 2004....................................................................36

Figura 18 - cordão grosso de algodão sobre placa cindida com forma convexa.

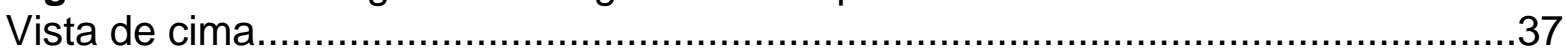

Figura 19 - Cordão grosso de algodão sobre forma côncava.

Betânia Silveira, São Paulo, 2004

Figura 20 - algodão grosso em forma de gesso, côncava. Betânia Silveira,

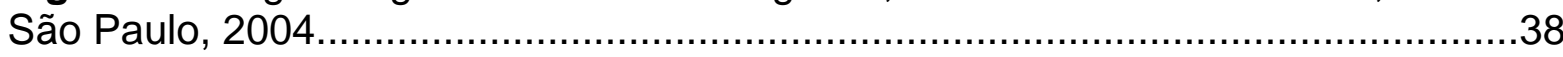

Figura 21 - Algodão grosso em forma de gesso, côncava. Detalhe do

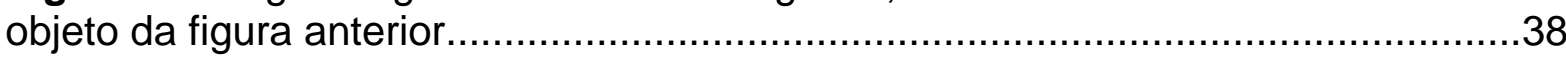

Figura 22 - Algodão grosso em forma de gesso, côncava. Detalhe........................39

Figura 23 - Cordão grosso de algodão embebido de barbotina sobre bolas de papel jornal. Betânia Silveira, São Paulo, 2004.

Figura 24 - Fragmentos de cerâmica feitos com ramas de coqueiro

recobertas de barbotina. Betânia Silveira, São Paulo, 2004.

Figura 25 - Detalhe imagem anterior.

Figuras 26 - Cerâmicas feitas com ninhos de gravetos recobertos

com barbotina. Betânia Silveira, Florianópolis, SC. 2004.

Figuras 27 - Cerâmicas feitas com ninhos de gravetos recobertos

com barbotina. Betânia Silveira, Florianópolis, SC. 2004

Figura 28 - "Ítalo, Valeska, o Pássaro e Eu." Cerâmica, vidro e espelho

impresso. Betânia Silveira. Salão Nacional de Cerâmica, Curitiba, PR, 2006.........43

Figura - 29 - "Ítalo, Valeska, o Pássaro e Eu". Detalhe.......................................43

Figura - 30 - "Ítalo, Valeska, o Pássaro e Eu". Detalhe.........................................43 
Figura - 31- "Ítalo, Valeska, o Pássaro e Eu". Detalhe 44

Figura - 32- "Ítalo, Valeska, o Pássaro e Eu". Detalhe

Figura 33 - Cerâmica com fios feitos por compressor manual.

Betânia Silveira, Florianópolis, 2004

Figura 34 - Vista lateral do grupo de objetos de cerâmica, de fios feitos.

por compressor manual.

Figura 35 - Fragmentos de cerâmica reaproveitados em caixas feitas com barbotina em placas de gesso. Fragmentos geométricos de espelhos.

Betânia Silveira, São Paulo, 2004

Figura 36 - Detalhe caixas feitas com barbotina em placas de gesso.

Fragmentos geométricos de espelhos. Betânia Silveira, São Paulo, 2004 


\section{LISTA DE ABREVIATURAS}

CEARTE/UDESC....... Centro de Artes da Universidade do Estado de Santa Catarina $\mathrm{CIC}$ Centro Integrado de Cultura FPOLIS Florianópolis MASC Museu de Arte de Santa Catarina

SC

Santa Catarina 
This document was created with Win2PDF available at http://www.daneprairie.com. The unregistered version of Win2PDF is for evaluation or non-commercial use only. 
INTRODUÇÃO 
Se suprimisse tudo o que devo aos meus predecessores, restaria pouco. Minha obra é a de um ser coletivo que se chama

Goethe.

(GOETHE)

Os registros históricos deixados pelos nossos antepassados evidenciam que, desde o período neolítico, a cerâmica é uma atividade em constante desenvolvimento. Em sua história, segundo consta em Cooper (1987), de início, a cerâmica caracterizou-se como um artefato a serviço da sobrevivência e da manifestação da interioridade e crenças dos povos primevos. Mas ao longo dos tempos, vem açambarcando uma série extensa de itens desenvolvidos pelas necessidades e ações humanas. Sendo assim, esta versatilidade da cerâmica se manifesta também sobre um outro viés, o da arte, através de inúmeras esculturas e amuletos, potes, muros e murais que o homem deixou.

$\mathrm{Na}$ contemporaneidade a cerâmica é utilizada, de forma diversificada, do piso ao teto, de dentes a facas, de louças a fios condutores de eletricidade, do utilitário ao artístico. Portanto, a cerâmica expressa, fortemente, a passagem e o estar do homem no mundo, seu percurso civilizatório, sua evolução.

Através dos descobrimentos arqueológicos, pode-se observar o quanto a cerâmica e seus registros nos auxiliam a adquirir conhecimentos sobre os diversos povos e suas culturas, em diferentes épocas. Isto é, a desvendar e compreender melhor a história da humanidade e logo, a refletir sobre esse trajeto.

Em seu processo constitutivo, transformações físico-químicas realizam uma nova matéria que não se desfaz com a água e resiste a ação do tempo. O ser humano participa ativamente do desenrolar destas transformações, é motor e mediador da combinação dos elementos naturais que fazem parte da realização desta matéria em questão. Transformar a argila em cerâmica para materializar objetos que não apenas garantam nosso conforto ou expressem nosso lado sensível, mas que sem dúvida, 
representam o registro da diversificada atividade humana, é também repetir o ato da natureza ao criar rochas e minerais.

A cerâmica envolve-nos num fazer cujo processo nos coloca em contato direto com a natureza, seus elementos minerais, geográficos e climáticos, assim como nos faz participar do mundo dos objetos produzidos pelo desenvolvimento industrial e tecnológico. Portanto exige que, paradoxalmente, estejamos conectados a uma espécie de retorno à natureza e, ao mesmo tempo, a um distanciamento da mesma.

Embora sua existência preceda ao evento do pensamento científico, a cerâmica tem se desenvolvido sobremaneira com as contribuições próprias do progresso da ciência, tornando-se material para tecnologia de ponta. Embarca nos foguetes rumo à conquista sideral; como material bioativo tem sido pesquisada para substituir ossos humanos (Jornal O Estado de Minas, 2003) e favorece com o silício (um dos elementos básicos da argila, sua matéria prima) à existência do mundo virtual nos computadores.

Os séculos XX e XXI são marcados pelo avanço tecnológico e o desenvolvimento dos meios de comunicação. Vivemos a era da globalização, processo que enfatiza a ação das novas tecnologias que, por sua vez, influenciam novos hábitos, comportamentos e formação de toda a sociedade contemporânea, alterando valores e identidades. As técnicas e processos da cerâmica, assim como a discussão de questões poéticas e reflexivas sobre seu fazer e sua produção, acredita-se também, que podem estar ligados à rapidez, inventividade, multiplicidade e interatividade próprias do mundo virtual.

É neste sentido que se propõe a produção de um $C D$-ROM híbrido, isto é, que além de suas características multimídia, poderá se conectar à grande rede da internet. Através das imagens de processos e resultados da pesquisa com a cerâmica como material expressivo este $C D$-ROM proporcionará uma vivência estética e informativa, cujo conteúdo abordado refere-se ao fazer cerâmico com suas conexões e procedimentos conectados à hipermídia. 
Entende-se por estética a condição deste trabalho que propõe uma outra percepção do cotidiano da cerâmica. Aqui o conteúdo estético, não se limita a associações com o belo, harmônico e equilibrado, mas a outras categorias poéticas, como as transformações da matéria e o gestual entretecidos a novas possibilidades técnicas oferecidas pelo mundo virtual, a diversidade como fonte de conhecimento, e as ressonâncias e ligações entre todos esses elementos, pessoas, práticas e obras aqui apresentadas. Neste caso, este $C D$ desta forma constituído, mostrando a cerâmica como saber técnico e material expressivo, resgata a idéia grega de téchne, cujo sentido tanto está ligado à invenção técnica quanto à expressão artística.

A rapidez da circulação de informações coloca o ser humano atual em conexão com o mundo. Como todo tipo de conhecimento, a arte enquanto fazer cerâmico, que é o foco deste trabalho, conta com novos meios para sua expressão e propagação. Na busca de maior integração dessas tecnologias aos processos artísticos, tanto quanto aos educativos, recursos como, por exemplo, softwares, $C D$, DVD-ROM e internet podem ser incorporados, também, aos projetos destas áreas.

Nesta era da informação e da imagem, graças às novas tecnologias, é possível representar o mundo atual (espacialidade aliada à temporalidade) em um mundo virtual (apenas temporalidade, pura e simples ausência de presença), tão real quanto o anterior e no qual se pode estar imerso e participar de ações que favoreçam a expressão poética, tanto quanto a assimilação de novos conhecimentos técnicos e teóricos.

A informática, instrumento no desenvolvimento de novos produtos e novas produções artísticas tem sido utilizada também como recurso, dinâmico e desterritorializado, no processo de aquisição de conhecimento. Entende-se, neste caso, a desterritorialização como uma possibilidade de abrangência, onde o conhecimento específico que agora circula, pode ser rapidamente apropriado por muitos, acrescido e incorporado de novas contribuições, como no caso de sites interativos onde o visitante não só acessa o 
conhecimento ali encontrado como também é convidado a fazer suas interferências, contribuindo desta forma, para o enriquecimento do hipertexto que está acessando.

O silício, matéria prima básica da cerâmica, também é parte concreta dos computadores. Em contrapartida, se pode tirar proveito desta tecnologia para, além dos efeitos multimídia, acessar e difundir conhecimentos sobre a cerâmica, seus processos e produção poética.

Ao participarmos desta nova forma de processar o saber com o uso de um CD-ROM híbrido sobre a cerâmica, que lide com a publicação na Web, enriquecendo os elementos estáticos do CD, amplia-se a complexidade do trabalho com a cerâmica.

O mundo virtual associa imagens estáticas e em movimento a sons e textos, podendo oferecer-nos um contato amplo com os processos que constroem a cerâmica, seus produtores e artistas dos mais diversos lugares, possibilitando uma nova forma de veicular poéticas e processar o desdobramento de conhecimentos específicos desta área.

Sob outro aspecto de abrangência e cunho social, este $C D$-ROM pode como material de consulta, facilitar a tarefa para professores e enriquecer os recursos pedagógicos. Para um autodidata, este pode ser um meio rico, lúdico e interativo para adquirir e socializar o conhecimento cerâmico.

Lévy (1993) denomina estas tecnologias como "tecnologias inteligentes", pois possibilitam um outro modo de pensar, uma outra forma de construção do conhecimento pautada numa lógica não mais linear, mas hipertextual.

De acordo com Editorial 37 (2004), Ana Mae Barbosa foca uma outra questão urgente na educação artística nas escolas no tocante à utilização das novas tecnologias. "Como ver, como ouvir, como aprender e ensinar as artes aliadas às novas tecnologias?" 
Questões como estas levantadas por profissionais da área da educação, não são aqui objeto de estudo e análise e por isso não serão aprofundadas, embora se considere importante apontar para a abrangência de investigação relativa a este campo da comunicação.

Nesse sentido, a cerâmica em hipermídia oferece uma rica possibilidade de contato com teorias, profissionais, técnicas, produções e poéticas, podendo contribuir no processo de ensino/aprendizagem, em que, para a cerâmica, as mãos na massa constituem a grande vivência. Isto quer dizer que esta forma, própria do universo da informática, de passar conhecimento e mostrar produções plásticas da cerâmica, não anula nem substitui formas tradicionais do aprender fazendo. Apenas propõe-se a enriquecê-las.

Através do $C D$-ROM, "Tecer o Barro" ${ }^{1}$ é possível:

a) Apresentar um trabalho sobre a cerâmica e em hipermídia, que se realiza, inicialmente, a partir da vivência expressiva da autora com a matéria argila em atelier passando, de forma entrelaçada, a uma realização multimídia.

b) O conhecimento de técnicas e processos do fazer cerâmico assim como o de profissionais (artistas, artesãos, designers) que, com seus depoimentos, contribuirão para ampliar conhecimento, conceitos e suscitar reflexões sobre esta atividade milenar e suas possibilidades plásticas e poéticas.

Por suas características híbridas possibilitará ao leitor e interator estar conectado à Internet e assim fazer parte de uma grande rede de conhecimento, experiências, trocas. Para isto, através de um site se fará links informativos. Além disso, será disponibilizado um endereço de correio eletrônico para a troca de mensagens que os visitantes poderão estabelecer. Isto é, disponibilizar-se-á conexões para comunidades virtuais, e que se toma emprestada para dar título ao $C D-R O M$ em questão. 
grupos de discussão e links de interesses que possam promover trocas de idéias e experiências sobre a cerâmica que, como material expressivo e que exige conhecimento técnico, será acessada e seu conhecimento transmitido e construído. 

"Tecer o Barro". 
Para que olhar para trás, no momento em que é preciso arrombar as portas do impossível.O tempo e o espaço morreram ontem. Vivemos já no absoluto, pois criamos a eterna velocidade onipresente. (MANIFESTO FUTURISTA, MARNETTI)

Este trabalho acata o conceito de hipermídia definido por Machado (1997) como sendo uma forma combinatória, permutacional e interativa de multimídia ${ }^{2}$ onde textos verbais, sons e imagens estáticas ou em movimento estão associados e podem acontecer, através do simples toque de clicar o mouse. Entretanto outros conceitos corroboraram para discutir a hipermídia nesta pesquisa como se pode observar ao longo do texto e em notas de rodapé.

Estas várias mídias ${ }^{3}$, associadas de forma não linear e conectadas por nós de informação (link), compõem um tipo de texto denominado hipertexto. Deleuze e Guatari (2000) o definem como uma espécie de labirinto onde um conjunto de palavras, imagens e sons se entrelaçam um ao outro no ato de tocar um elemento eletrônico.

Tendo em vista as conceituações de Machado (1997) para hipermídia e de Deleuze e Guatari (2000) para hipertexto, observa-se uma similaridade tal que, hipertexto e hipermídia parecem ser denominações diferentes para um mesmo processo ou sistema. Porém, esclarece-se que alguns autores estabelecem como característica imprescindível e definidora da hipermídia o fato de se ter que estar, obrigatoriamente, conectado à grande rede do sistema WWW, o que para efeito de análise desta pesquisa entra-se em comunhão com os propósitos a serem alcançados.

\footnotetext{
${ }^{2}$ Para Negroponte (1995), pensar em multimídia implica em se compreender um deslocamento fluente de um meio para o outro, dizendo as mesmas coisas de maneiras diversas, fazendo uso de vários dos sentidos humanos, concomitantes ou subsequentemente. Entende-se, portanto que multimídia é a utilização de muitos meios que, a um só tempo, pretendem explicitar o que se deseja transmitir como conteúdo. Porém, é importante ter claro que a mensagem não é o meio, apenas este se revela como uma de suas formas de tradução.

${ }^{3}$ Para Pierre Levy (1999) mídia é a linguagem utilizada, apenas aquilo que carrega a mensagem, ou melhor, é o suporte ou o veículo da mesma, portanto textos impressos, fotografias ou um vídeo são exemplos diferentes de mídia que podem aparecer, simultaneamente, digitalizados ou não, e desta forma constituir o que ele define como multimídia.
} 
Para Aarseth (apud Leão, 1999) a principal característica do hipertexto em relação aos textos impressos, também passíveis de serem não lineares, é o salto que se pode fazer entre uma informação e outra, ou mesmo, entre mídias diferentes abordando um mesmo assunto, acarretando num tipo de leitura descontínua onde o deslocamento se dá instantaneamente com o clicar do mouse."Assim, à medida que possibilita ligações rápidas a diversas redes associativas, o hipertexto se apresenta como um meio de compartilhamento de redes de relações, incitando conexões e o 'formigar dos sentidos'! como diria Levy." (LEÃO, 1999, p.16)

O hipertexto, este composto de espaços textuais conectados por nós de informação (link) que podem ser percorridos por saltos associativos, tem seu processo de leitura designado, segundo Machado (1997), pela pertinente metáfora da navegação ${ }^{4}$. Neste caso, explica, é como se o interator "navegasse" num mar de múltiplas possibilidades de textos que se tangenciam ou se superpõem.

\begin{abstract}
Na sua forma mais avançada e limítrofe, a hipermídia seria algo assim como um texto verbo-audiovisual escrito no eixo do paradigma, ou seja, um texto que já trás dentro de si várias outras possibilidades de leitura e diante do qual se pode escolher dentre várias alternativas de atualização. Na verdade, não se trata mais de um texto, mas de uma imensa superposição de textos, que se pode ler na direção do paradigma, como alternativas da mesma escritura, ou na direção do sintagma, como textos que correm paralelamente ou que se tangenciam em determinados pontos, permitindo optar entre prosseguir na mesma linha ou enveredar por um caminho novo. (MACHADO In: Domingues, 1997, p.146).
\end{abstract}

Um outro conceito de hipermídia destacado neste trabalho diz respeito a Leão (1999), que acrescenta que esta é uma tecnologia que, por apresentar uma escrita - leitura não linear favorece ao desenvolvimento de um pensamento complexo.

\footnotetext{
${ }^{4}$ Navegação: metáfora utilizada para a forma de fazer a leitura, o transitar, o movimento do leitor dentro do sistema hipermídia e seus aplicativos e cujo prazer pode ser maior ou menor de acordo com as facilidades de identificação da localização das informações assim como sua apresentação.
} 
Ainda, segundo Machado (1997) se o labirinto ${ }^{5}$ é a metáfora da hipermídia a metáfora do labirinto é o pensamento. Isto significa que quando experimentamos a hipermídia fazemos um trajeto parecido com aquele que faz o nosso pensamento, usamos da associação livre e suas conexões para construir a idéia ou o conhecimento que queremos comunicar.

Desta forma, a idéia do labirinto sugere várias entradas e uma possibilidade de se perder sem nunca encontrar a saída. Mas no caso da hipermídia, num hipertexto é mais importante fazer o percurso do que chegar a um destino. Enveredar-se no processo de elaborar seu conhecimento exige que o indivíduo desenvolva seu pensamento de forma complexa.

No formato deste $C D$ - $R O M$ encontra-se um labirinto, além daquele grande, próprio da internet, que apesar de menor, não perde sua característica de possuir vários centros não hierárquicos de onde se pode partir. Em sua navegação o leitor escolherá, via associação livre, aonde ir e o quê absorver do conteúdo.

O caráter híbrido trará a este $C D$ uma combinação de características especificamente centradas e lineares (como a dos vídeos que se pode encontrar nele), com pontes poli centradas de acesso, próprias do hipertexto.

Num aplicativo hipermidiático como este, as escolhas que farão os usuários tornam-se imprevisíveis e para isto, teremos traçado, anteriormente, em sua programação os caminhos permutacionais possíveis assim como suas portas e pontes de acesso. Desta maneira por mais que se façam saltos e o percurso pareça caótico, na verdade está se percorrendo um caminho previamente projetado e organizado.

\footnotetext{
${ }^{5}$ Labirinto: espaço composto de grande número de divisões, corredores, galerias, e de feitio complicado para se encontrar a saída. Como entendido por Machado (1997), o labirinto é a metáfora da hipermídia e seu funcionamento se dá como o pensamento, fazendo cortes e saltos associativos para construir um "corpo".
} 
Para esta dita navegação torna-se necessário que o leitor passe a interator, isto é, imerso ${ }^{6}$ neste universo e interagindo com ele através das interfaces ${ }^{7}$ disponíveis, tornese um agente dentro do sistema, determinando o trajeto e a construção de seu conhecimento, podendo se comunicar com outros interatores e trocar experiências.

Como as visitas a $W e b^{8}$, da mesma forma, serão propiciadas através deste híbrido, os nós da rede também serão visitados em percursos muito pessoais e não determináveis a priori, o que segundo Leão (1999) por serem tantos os fatores que poderão interferir no caminho a ser percorrido na rede, estar-se-á diante de uma hipercomplexidade.

Através deste $C D$, cada individuo pode imprimir seu ritmo próprio ao andamento e construção do seu conhecimento. Também é pessoal a forma como se dará cada fruição. Como o ato de atribuir sentido e a apreensão que se pode fazer das informações vão depender de operações associativas de cada leitor, diferentes leitores poderão apreender ou dar diferentes sentidos, respectivamente, a um mesmo texto ou a uma mesma obra apresentada.

Portanto, é fundamental deixar claro, que, ao desenvolver este trabalho, é um coletivo que o faz. A forma de construção e navegação deste $C D-R O M$ utiliza as imagens da

\footnotetext{
${ }^{6}$ De imersão: Segundo Machado (2003), este termo foi introduzido recentemente, no mundo da realidade virtual e dos videogames, para referir-se à maneira como a pessoa entra e pode percorrer o mundo das imagens e sons próprios do computador. Assim, em ambientes virtuais quanto maiores as condições de imersão, mais fáceis e prazerosas serão a navegações.

De acordo com Murray (2003), na imersão (metáfora construída a partir da experiência física de se estar completamente mergulhada na água) tem-se a sensação de um envolvimento completo em uma outra realidade diversa daquela que se experiência no espaço e tempo real, onde toda nossa atenção e nosso sistema sensorial estarão absortos. A imersão é uma atividade participativa e como tal, reivindica a ação da pessoa envolvida, para quem se usa a denominação de interator.

${ }^{7}$ Segundo Levy (2000) são todos os aparatos materiais que permitem a interação entre o universo da informação digital e a pessoa que usa esta tecnologia. Porém, o conceito de interface ampliado refere-se a algo que faça a "mediação" entre quaisquer duas coisas diferentes. Não precisa ser, exclusivamente, recursos materiais (como as luvas de RV - Realidade Virtual - ou mouse por exemplo), pois existem, também, as interfaces gráficas de websites que são digitais e não materiais, intermediando o ser humano com o computador ou com o mundo virtual.

Através da intermediação propiciada pelas interfaces podemos navegar.

${ }^{8}$ Sistema www, rede ou Internet: grande rede mundial de computadores interconectados por meio de telecomunicações.
} 
produção em cerâmica desta autora, sua expressão poética, suas pesquisas individuais, seus conhecimentos teóricos e práticos adquiridos ao longo dos anos trabalhando com a cerâmica, associados a uma soma de outros conhecimentos transmitidos por outros profissionais da área, professores, alunos e colegas. O que poderia ser descrito segundo Deleuze e Guatari (2000, p.37), como um agenciamento coletivo. "Há um agenciamento coletivo de enunciação, um agenciamento maquínico de desejo, um no outro, e ligados num prodigioso fora, que faz multiplicidade de toda maneira".

Este conteúdo compõe, com imagens e sons, uma espécie de rizoma, onde tudo se interconecta e permanece aberto, como meio, a novas e infindáveis alianças. Rizoma é um termo emprestado da botânica que se refere aos bulbos e tubérculos, órgãos geradores de outras plantas e que, quando apropriado por Deleuze e Guatari (2000), diz respeito ao que se conecta por todos os lados e faz alianças, como uma linha do meio.

Um rizoma não cessaria de conectar cadeias semióticas, organizações de poder, ocorrências que remetem às artes, às ciências, às lutas sociais. Uma cadeia semiótica é como um tubérculo que aglomera atos muito diversos, lingüísticos, mas também, perceptivos, mímicos, gestuais, cogitativos... (DELEUZE; GUATARI, 2000, p.16).

É pertinente afirmar que muitas "vozes" se manifestam neste $C D$ através dos depoimentos, da realização e demonstração de técnicas, dos textos verbosaudiovisuais, das imagens de diversos trabalhos e da não linearidade na forma de realizar a navegação feita pelo interator. Esta determina que cada um possa percorrer um caminho diferente e, diversamente, fazer suas relações e construir seu conhecimento. $\mathrm{O}$ interator como agente, pois age dentro de um evento e através desta sua ação é que o evento acontece terá oportunidade de dar um caráter bastante pessoal e único ao percurso. Como diria Machado (1997), também aqui a obra se realiza no ato da leitura. 
Murray (2003) considera enganosa a afirmação de que o interator possa ser co-autor, e refere-se à possibilidade do mesmo ser autor de um desempenho particular dentro do sistema. Para Murray (2003), a agência ${ }^{9}$ vai além da participação e da atividade. Nela o interator também determina rumos, provoca mudanças.

Ainda que esta conceituação de autoria derivativa seja pertinente, entende-se aqui que o leitor desempenha certo papel "fundante" como co-autor, e contribui decisivamente para a realização da obra, pois, será ele o autor de seu aprendizado e do percurso que fará para isso. Acredita-se que é só na concretização deste fato que se dá o sentido pleno de um trabalho como este. Para isto torna-se imprescindível a interatividade ${ }^{10}$, onde a "voz" de cada leitor se fará presente nas escolhas que fizer em sua navegação, em seu processo de leitura e de re-significação de sentidos, assim como na possibilidade de se estabelecer um diálogo com o sistema de expressão que pode se estender a uma troca de experiências possibilitada nos sites que estarão acessíveis a partir deste aplicativo.

Esta multiplicidade de "vozes" estabelece desta forma, não a perda, mas sim a diluição da autoria, pois num objeto como este, onde reside uma mestiçagem de caráter poético e informativo, espécie expressiva de livro virtual, o nome que assina é apenas um agenciador de significações.

Num livro, como em qualquer coisa, há linhas de articulação ou segmentaridade, extratos, territorialidades, mas também, linhas de fuga, movimentos de desterritorialização e desestratificação... Tudo isto, as linhas e as velocidades mensuráveis, constitui um agenciamento. Um livro é um tal

\footnotetext{
${ }^{9}$ Agência é a capacidade do interator de realizar ações significativas determinadas por sua decisão ou escolha. A agência se dá desde o simples clicar um arquivo e ele se abrir até a utilização de um avatar substituto virtual para o sujeito interator, cujo nome, sexo e descrição física serão designados e construídos por ele, podendo tomar a forma de uma figura humana ou não - ou mesmo de uma câmera subjetiva - tipo de construção cinematográfica onde vai haver uma coincidência entre a visão dada pela câmera ao espectador e a visão do próprio personagem.

${ }^{10}$ Interatividade é a condição bidirecional da comunicação que permite que o leitor atue sobre o produto ou sistema e dele receba resposta. Trata-se da capacidade de ação e reação entre a pessoa e o hipertexto, em tempo real e contínuo.
} 
agenciamento e como tal, inatribuível. É uma multiplicidade. (DELEUZE; GUATARI, 2000, p.11-12)

Afirma-se assim, que são muitas as vozes que falam e sempre vai sobressair a do enfoque do momento. Pois, concorda-se com Caldas (2003), ao definir o "autor" como sendo somente aquele que reescreve e corporifica momentaneamente num "texto", sua hiperleitura. Ou seja, como aquele que se deixou atravessar por um fluxo e dialogou com ele.

Desta forma, o $C D$ permite que diversos posicionamentos e expressões tão distintas se manifestem. Através da participação dos vários profissionais, pode-se observar diferentes entendimentos para o conceito de cerâmica, ações diversificadas para realizar uma mesma técnica, assim como múltiplas formas de expressão, valores estéticos e éticos. Com isto, este $C D$ propõe um olhar mais amplo e visa à possibilidade de frutificar o debate na discussão e ampliação dos conceitos que envolvem a cerâmica e sua prática. 
3

PROCEDIMENTOS METODOLÓGICOS 
O saber não basta, temos de aplicá-lo. A vontade não basta, temos de atuar. (GOETHE)

Para esta dissertação alguns procedimentos metodológicos foram acontecendo à medida que ia se desenvolvendo a idéia da pesquisa. Neste sentido, se descreve os passos metodológicos produzidos e os procedimentos que se efetivaram.

Primeiramente, desenvolveu-se em ateliê e com o material cerâmico uma pesquisa com diversas fibras recobertas de argila liquida, para a produção de objetos onde a trama, as conecções e entrelaçamentos de fios estruturaram formas e texturas. Desta maneira o conceito de interligação ganhou um corpo cerâmico.

Foram realizados registros deste processo (fotográficos e em vídeos digitais), assim como dos objetos finalizados, que foram utilizados, ao lado de outras imagens e outras produções plásticas, para dar ao $C D-R O M$ seu contexto poético. Algumas destas imagens foram escolhidas para desenvolver os meios de navegação.

Concluída esta fase, passou-se a buscar no referencial teórico sobre a cerâmica, através de levantamento, leitura e análise de textos bibliográficos, artigos de jornais, revistas, sites especializados, fundamento conceitual que desse o suporte cientifico a esta pesquisa, assim como referências que fundamentam os textos que compõe o hipertexto dentro deste aplicativo.

Especialmente para este trabalho, foram captados e editados vários vídeos, contendo entrevistas e procedimentos técnicos sobre a cerâmica. Utilizou-se imagens digitais (fotográficas e scaneadas), animações e textos escritos, com a finalidade de desenvolver os conteúdos que contribuem para o assunto em questão.

Em seguida, foram desenvolvidas as telas do sistema e das animações, através de formatadores de arquivos (que podem melhor compactar e fragmentar vários vídeos), assim como através do uso de software de edição de apresentações. 
Estas telas apresentam o conteúdo poético/teórico/técnico do trabalho no formato hipermídia, isto é, com todos os recursos descritos anteriormente fazendo conexões entre si, desde a apresentação até a bibliografia.

Foram incorporadas às telas deste $C D$ imagens do processo e de trabalhos cerâmicos desenvolvidos pela autora no laboratório de ateliê da USP, no período do segundo semestre de 2004, assim como outras imagens de suas produções, no campo da escultura e da cerâmica, desenvolvidas ao longo dos muitos anos de experiência profissional.

Para as telas foram elaboradas e aplicadas cores e texturas que são encontradas na cerâmica e nos diversos tipos de argilas. Procurou-se usar destas características para salientar o universo da cerâmica, os resultados dos inúmeros estágios de seu processo como também, para tornar agradável o contato e a utilização do $C D-R O M$.

As mesmas são complementadas por um ícone (imagem de uma trama de cerâmica) que permite a movimentação dentro do sistema. Preparou-se para que este seja ativado com o posicionar da seta do mouse sobre títulos que representam o conteúdo a ser acessado no sistema. Da mesma forma, projetou-se que algumas palavras funcionassem como "palavras quentes", isto é, palavras chaves encontradas dentro dos textos e que uma vez clicadas dão lugar a outro texto, cujo conteúdo aprofunda ou ilustra o conhecimento.

As telas têm design gráfico elaborado para uma leitura fácil e uma navegação com possibilidades de conecções rizomáticas e de retorno. Desta forma disponibilizou-se uma espécie de "fio" que, a exemplo de Ariadne, orientará a volta do leitor que se perder no labirinto do $C D$.

Para a construção da navegabilidade dos textos encontrados no $C D$, optou-se por um tipo de construção conhecida por Bottom Up. Esta forma de tratar a informação procura 
aliar objetividade à navegabilidade, isto é, mantém a identidade do texto e garante uma navegabilidade menos pautada numa lógica estrutural pré-estabelecida.

Ao contrário de um livro comum, onde o sumário apresenta as informações de maneira hierarquizada, isto é, a partir de um índice com tópicos e sub-tópicos, este $C D$ se constrói através da fragmentação dos textos e ativação das conexões entre eles, preservando as relações entre as informações e não estabelecendo hierarquias.

Neste $C D$, as páginas foram desdobradas em unidades de informações, geralmente contidas em parágrafos curtos, facilitadores da identificação dos conceitos que movem o trabalho. Deste modo, as tramas são construídas a partir do texto, o que torna mais prazeroso identificar e estabelecer sua navegabilidade e hipertextualidade, propiciando um leitor mais interessado em buscar o conhecimento de forma personalizada, de acordo com o caminho e seleção das unidades de informação que the interessam. Sendo assim, a navegação se transforma no caminho que o leitor realiza para construir seu texto de informação.

Como forma de definir o conteúdo teórico e técnico do $C D$ procurou-se explicitar o que é a argila, sua formação, composição e transformações possíveis para resultar no material cerâmico. Consequentemente se faz necessário o conhecimento sobre as massas cerâmicas, seus componentes materiais, algumas possibilidades de queimas e tipos de fornos, o que nos levou mais uma vez aos recortes teóricos e observações praticas sobre a produção da cerâmica.

A seguir imagens do processo de fragmentação dos textos e da construção Bottom Up de sua navegabilidade e hipertextualidade utilizados na fase inicial do desenvolvimento da pesquisa: 


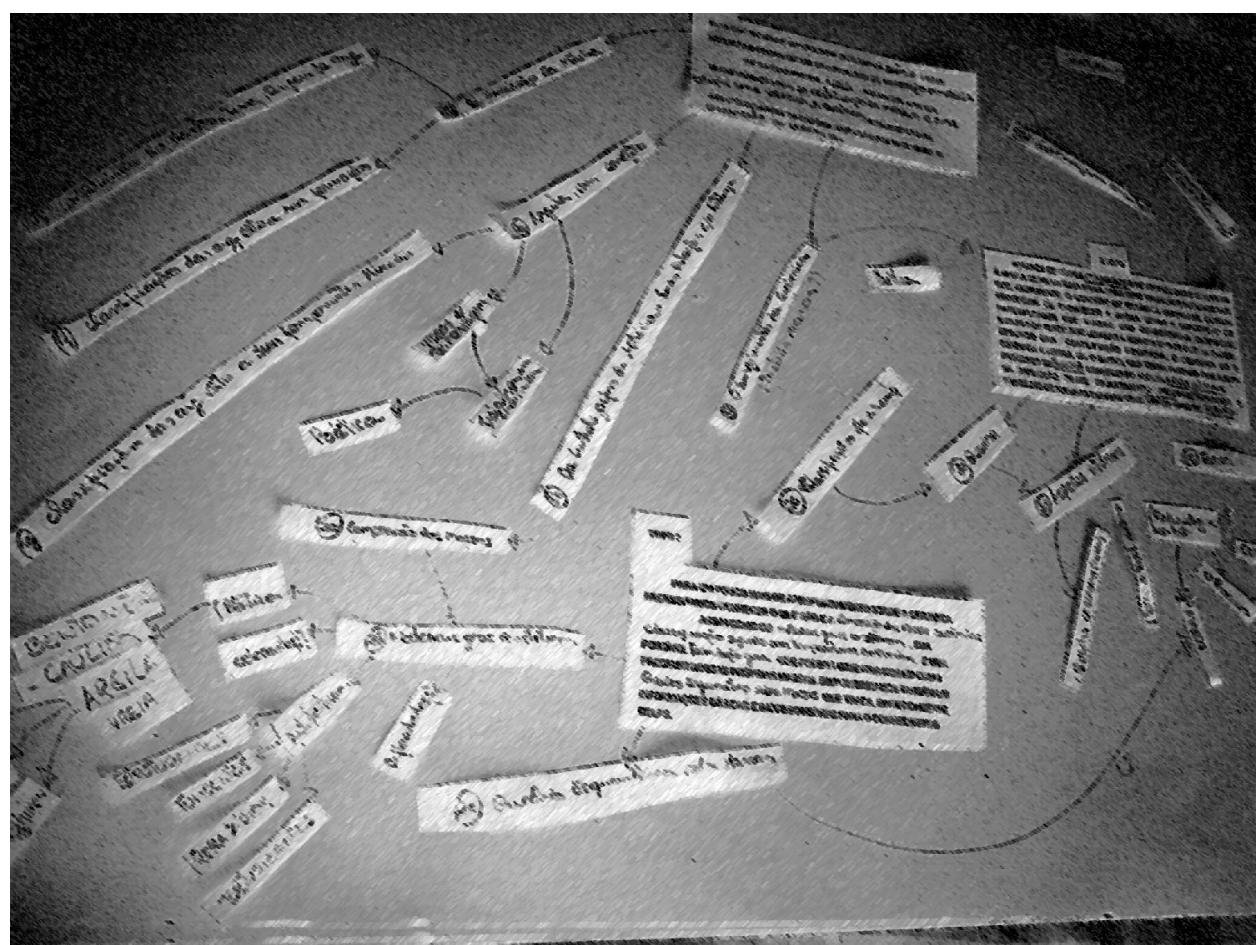

Figura 1 - Três tópicos e suas subdivisões, indicando a construção da trama. Fonte: A autora (2005).

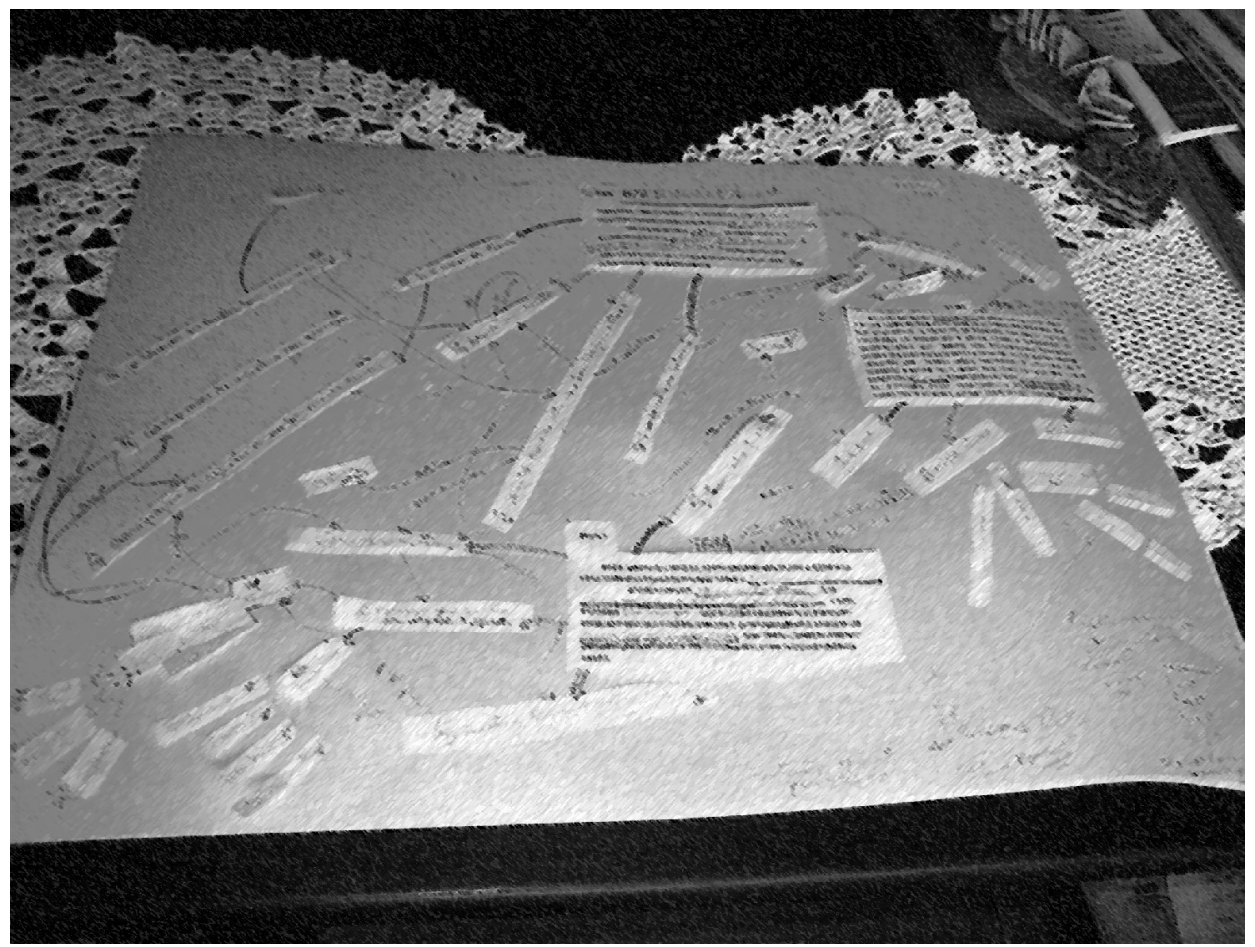

Figura 2-Três tópicos e suas subdivisões, indicando a construção da trama. Fonte: A autora (2005). 


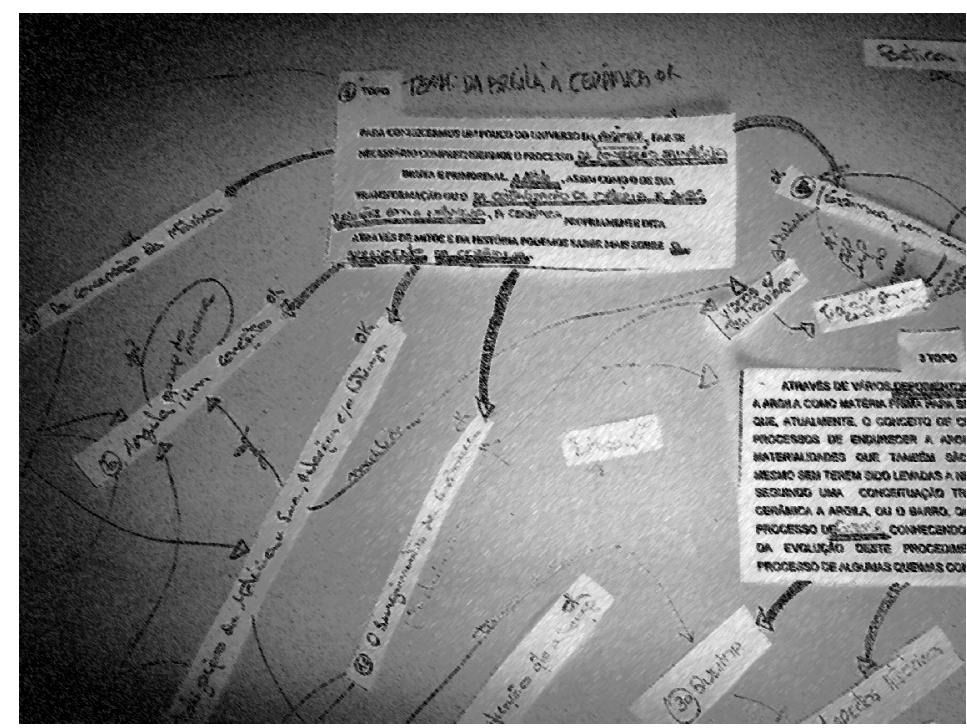

Figura -3 - Três tópicos e suas subdivisões, indicando a construção da trama.

Fonte: A autora (2005).

Com a trama destes textos estabelecida (figuras 1-2-3), passou-se à construção do entrelaçamento das imagens plásticas e poéticas da cerâmica entremeadas aos textos, depoimentos dos profissionais da área e suas produções, assim como aos vídeos que apresentam a realização das técnicas básicas de modelagem com o barro, montagens de fornos e execução de queimas.

Necessário se fez colocar imediatamente após a abertura do $C D$, três páginas iniciais que o leitor poderá escolher visitar para conhecer algo mais sobre a autora desta dissertação, algumas imagens de seus trabalhos de fases anteriores assim como a pesquisa plástica que vem desenvolvendo, sob o conceito inspirador da trama e da rede. Uma das três páginas é chamada "porta do labirinto", pois dali o hiperleitor passará a percorrer um grande e intrincado labirinto que o possibilitará ampliar seus conhecimentos de forma não linear e não hierárquica.

Dos requisitos de desempenho, configuração de sistema, segurança, acesso e instalação, o produto final os tem implementado de maneira correta e com uma qualidade significativa. Para isso, profissionais da área de sistemas de informação participaram do seu desenvolvimento, tendo por sua vez, ao final do trabalho, também sua assinatura justaposta a de todos os outros integrantes. 
ENTRELAÇADOS, UMA POÉTICA QUE SE CORPORIFICA EM CERÂMICA. 
"Um tecido nunca é feito de um único fio".

(DITADO CHINÊS)

\section{1 - DA TRAMA, AS INTER-RELAÇÕES.}

A partir do conceito de trama, no qual se apóia a idéia de que tudo na vida está interligado, desenvolve-se uma pesquisa com fios de algodão e fibras naturais recobertos de argila, para criar formas e texturas promovendo uma linguagem plástica.

Na rede que tece a vida tudo está em conexão, os seres vivos - animais e vegetais - o reino mineral, e até mesmo o mundo dos objetos artificiais, criados pelo homem. Como bem coloca Lévy (2001), as partículas elementares que vibram em nossos corpos aparecem nos primeiros momentos do universo e se originaram da mesma fonte de energia, da mesma grande explosão responsável pela criação. Quanto à vida no planeta, afirma: "Sabe-se que todos os seres vivos, micróbios, plantas e animais têm uma origem comum. É de um DNA inicial que derivam todos os DNAs" (LEVY,1992, p.177). Para este pensador francês da contemporaneidade o entrelaçamento que há entre todas as coisas que nos rodeiam se estende, inclusive para além das coincidências físicas ou coisas visíveis, como denominaria Ponty (1992).

Reconhecemos a existência de uma grande natureza física onde - obedecendo às mesmas leis - interagem todas as massas e todas as energias. Da mesma forma, deveríamos reconhecer a existência de um vasto espírito, no interior da qual (queiramos ou não, saibamos ou não) partilhamos não somente informações e idéias, mas também maneiras de ser, campos de ação, mundos subjetivos, emoções, energias vitais, e até intenções transpessoais que viajam de um espírito a outro. (LÉVY, 2001, p.165)

Bachelard (1993) define o homem como um ser entreaberto onde interior e exterior estão sempre em comunicação. Neste sentido, é preciso sair de nós mesmos para vasculhar e conhecer o mundo e assim trazê-lo para dentro de nós, absorvendo-o de forma muito pessoal, compreendendo-o muitas vezes, indagando-o sem respostas 
outras tantas vezes. Neste processo construímos o que se denomina EU. Portanto, estamos no mundo e ao mesmo tempo o mundo está em nós, fazendo parte daquilo que somos dando corpo a um entrelaçamento que gera o grande tecido universal. Nisso concorda Lévy (2001, p.166), quando afirma: "O interior e o exterior trocam continuamente seus lugares na dialética da experiência pessoal e da consciência coletiva".

Ponty (1992) indaga onde colocar o limite do corpo e do mundo e também aborda a idéia do entrelaçamento dos corpos. Para ele o corpo é um ser de duas faces, por um lado é coisa entre as coisas e por outro lado é aquilo que as vê e toca. Sendo assim, afirma que nossa pertinência às duas ordens, a do objeto e a do sujeito, nos revela relações muito inesperadas.

\footnotetext{
"Meu corpo como coisa visível está contido no grande espetáculo. Mas meu corpo vidente subtende este corpo visível e todos os visíveis com ele. Há recíproca inserção e entrelaçamento de um no outro". (PONTY, 1992, p.135)
}

Neste entrelaçamento de sentidos entre todas as coisas do mundo visível e invisível, dá-se a construção de uma grande trama que estrutura nosso ser-estar no mundo. Nesta rede onde tudo se interconecta, como bem aborda Levy (2001), não há sujeito nem objeto, o que realmente conta é o grande tecido da experiência que se desdobra continuamente.

\footnotetext{
"O que significa que cada visão monocular, cada palpação de uma única mão, embora tenha seu visível e seu tangível, está ligada à outra visão, à outra palpação, de modo a realizar com elas a experiência de um único mundo, graças a uma possibilidade de reversão, de reconversão de sua linguagem na delas, possibilidade de reportar e de revirar segundo a qual o pequeno mundo privado de cada um, não se justapõe àquele de todos os outros, mas é por ele envolvido, colhido dele, constituindo, todos juntos um sentiente em geral, diante de um sensível em geral' (PONTY, 1992, p.138)
}

\section{2 - DAS INTER-RELAÇÕES, O PERCURSO.}


Vem-se, desde o ano 2000, desenvolvendo como trabalho poético, que neste momento misturava a cerâmica ao plástico, ao acrílico e ao silicone quente, uma espécie de rede construída com fios muito finos de silicone, material que aos poucos se tornou contundente e tomou conta da aparência final de todos os objetos tridimensionais produzidos naquela fase. Estes trabalhos, redes muito delicadas, inicialmente, surgiram como formas semelhantes a casulos, ao longo de sua modificação se apresentaram como alusões a forma do corpo humano e depois se abriram completamente em forma abstrata. Saíram das salas expositivas de museus e galerias para circular em ônibus municipais em Florianópolis e habitar, por algumas horas, locais públicos de várias localidades.

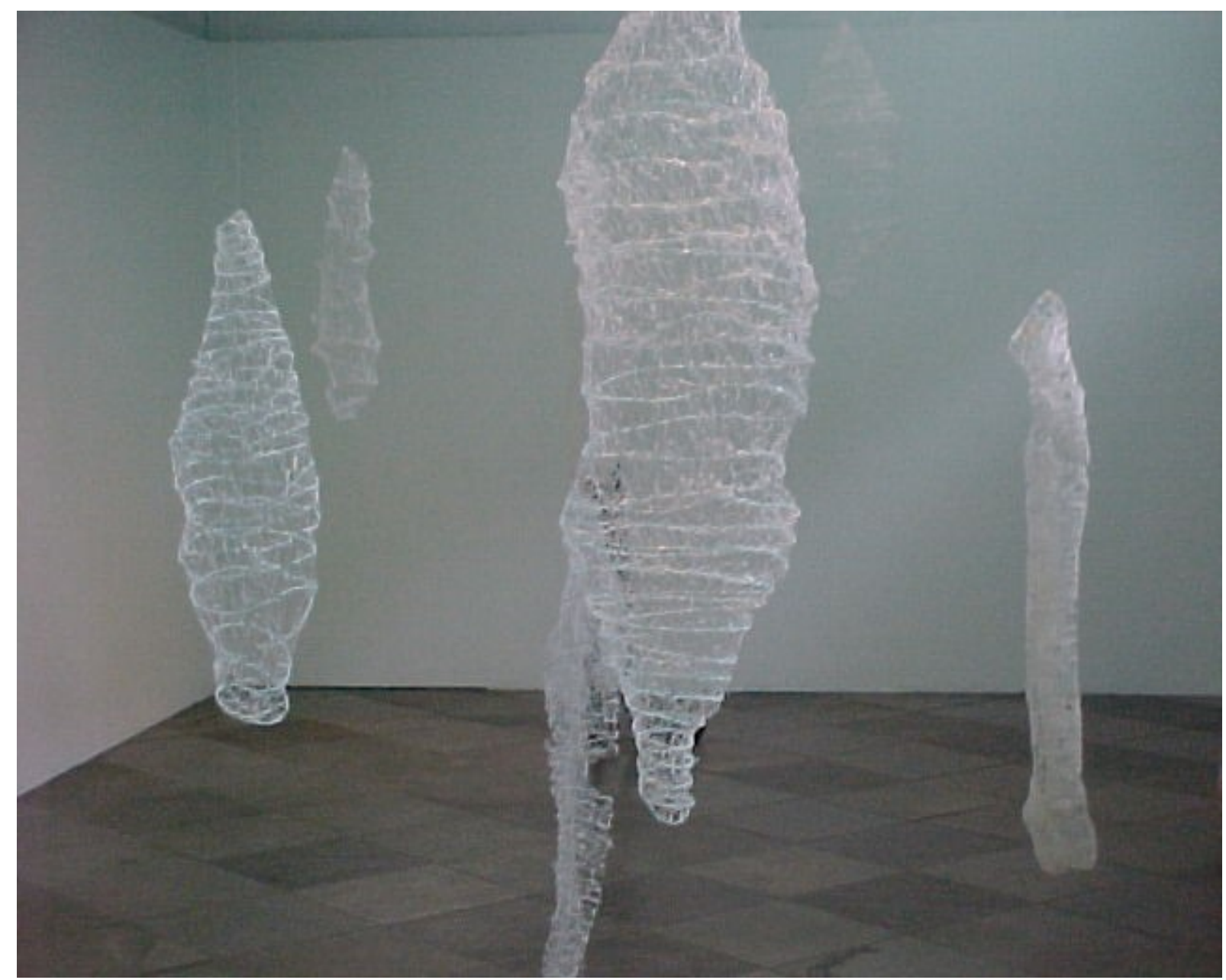

Figura 4 - DIAPHANA.Galeria das Oficinas de Arte do MASC/CIC Fpolis, Betânia Silveira. SC.2000. Dimensão: Área de $5 \mathrm{~m}^{2}$. Objetos variando entre $110 \mathrm{~cm}$ X $35 \mathrm{~cm}$ X $40 \mathrm{~cm}$ e $130 \mathrm{~cm} \mathrm{X} 45 \mathrm{~cm} \mathrm{X} 10 \mathrm{~cm}$. Fonte: A autora (2002) 


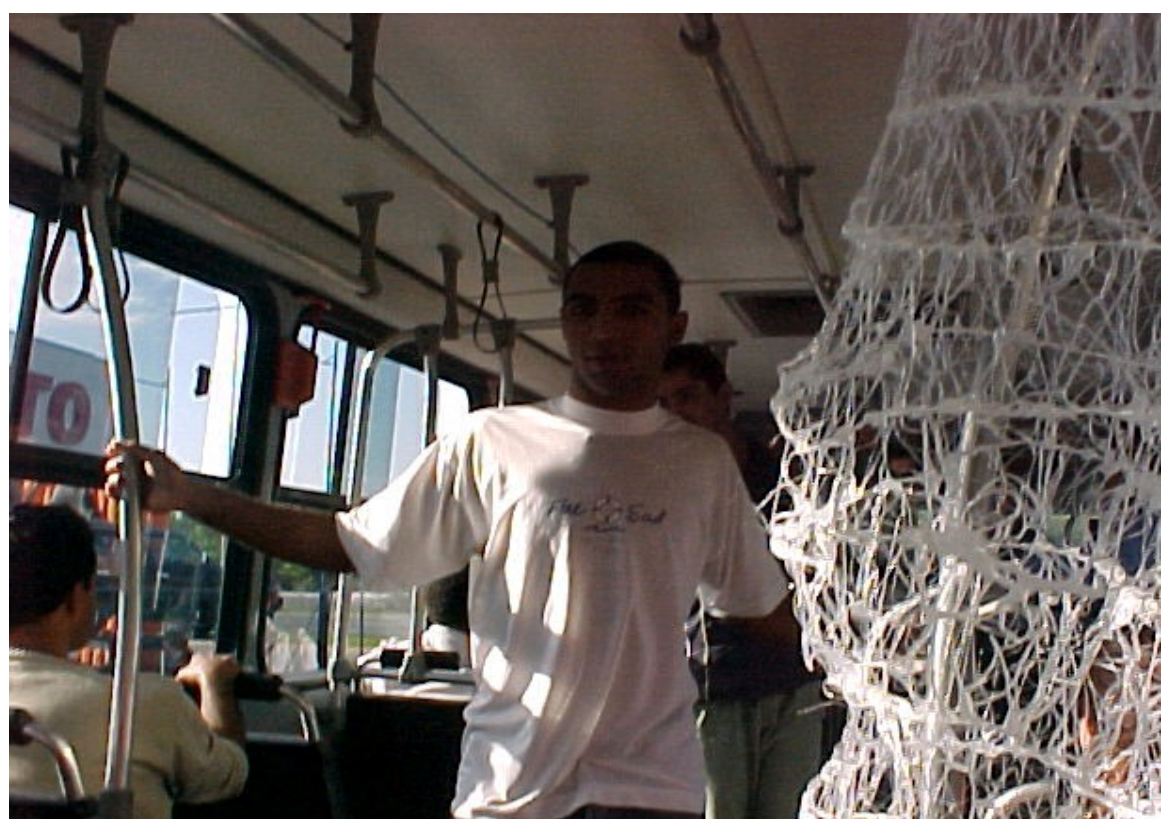

Figura 5 - DIAPHANA - Ação no ônibus. Betânia Silveira, Florianópolis-2002.

Fonte: A autora (2002)

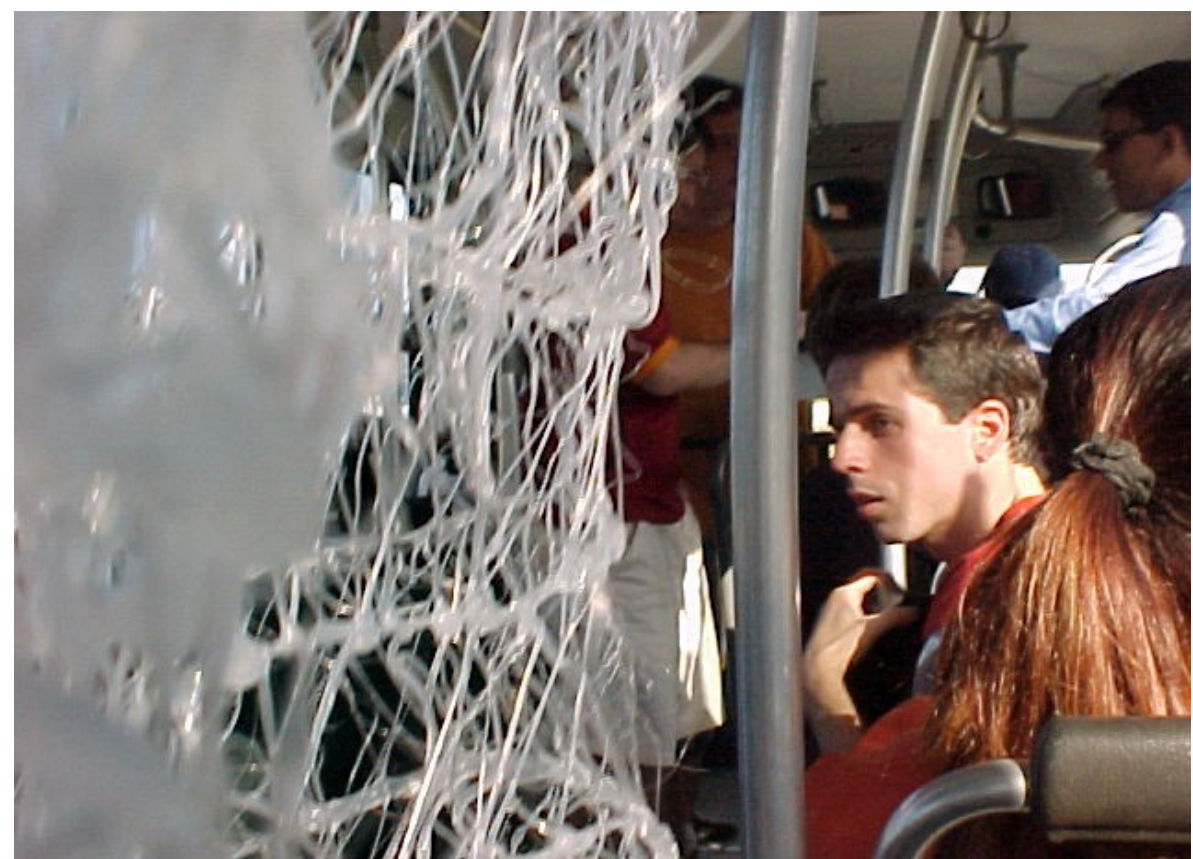

Figura 6 - DIAPHANA - Ação no ônibus. Betânia Silveira, Florianópolis-2002.

Fonte: A autora (2002)

Durante a disciplina "A Produção Tridimensional Contemporânea: A Arte da Instalação", também em 2004, orientada pelo professor Carlos Alberto Fajardo, através da análise 
dos trabalhos dos alunos, procurou-se reconhecer o que seria o foco de atenção da produção plástica de cada um. Ao longo do semestre pesquisou-se e buscou-se trabalhar sob o conceito de trama, não interessava nesse conceito seu aspecto de narrativa, não havia o desejo de construir ou contar uma história, apenas a trama, as teias, as interconexões. O vínculo desta produção com a dissertação que ora apresentamos, a princípio, era apenas conceitual, pois o material que se utilizava neste caso continuava a ser o silicone, desenvolvimento que seguia paralelamente a pesquisa com a cerâmica.

A seguir imagens do projeto realizado com rede de fio de náilon e silicone quente e desdobramentos, instalações e fotos que agora, também, integram o $C D$ :

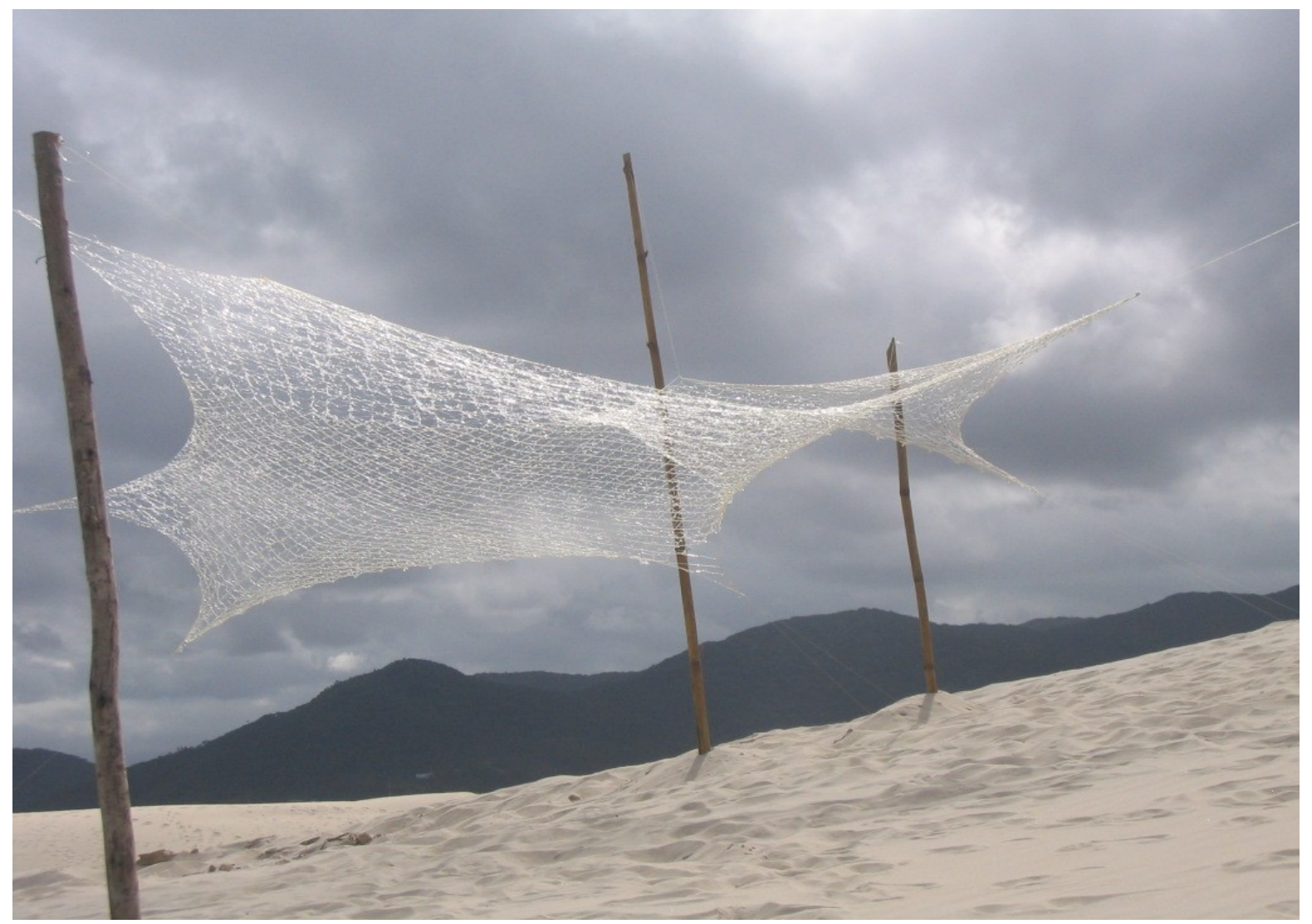

Figura 7 - DIAPHANA. Intervenção urbana, dunas da Lagoa da Conceição. Betânia Silveira. Fpolis, 2004. Dimensão: Área de $4 \mathrm{~m}^{2}$. Fonte: A autora (2004). 


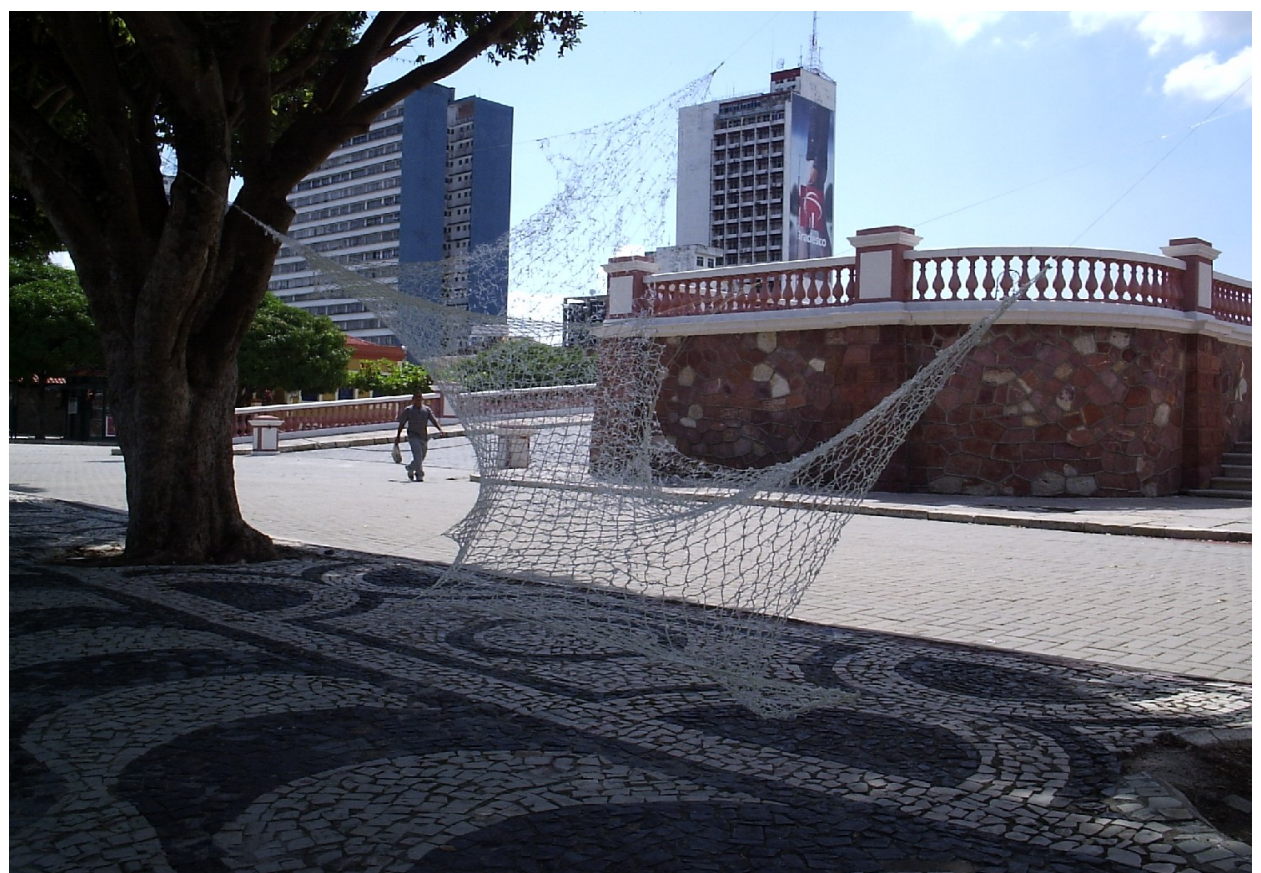

Figura 8 - DIAPHANA. Intervenção urbana, na praça do teatro de Manaus. Betânia Silveira. 2005. Dimensão: Área de $4 \mathrm{~m}^{2}$.

Fonte: A autora (2005).

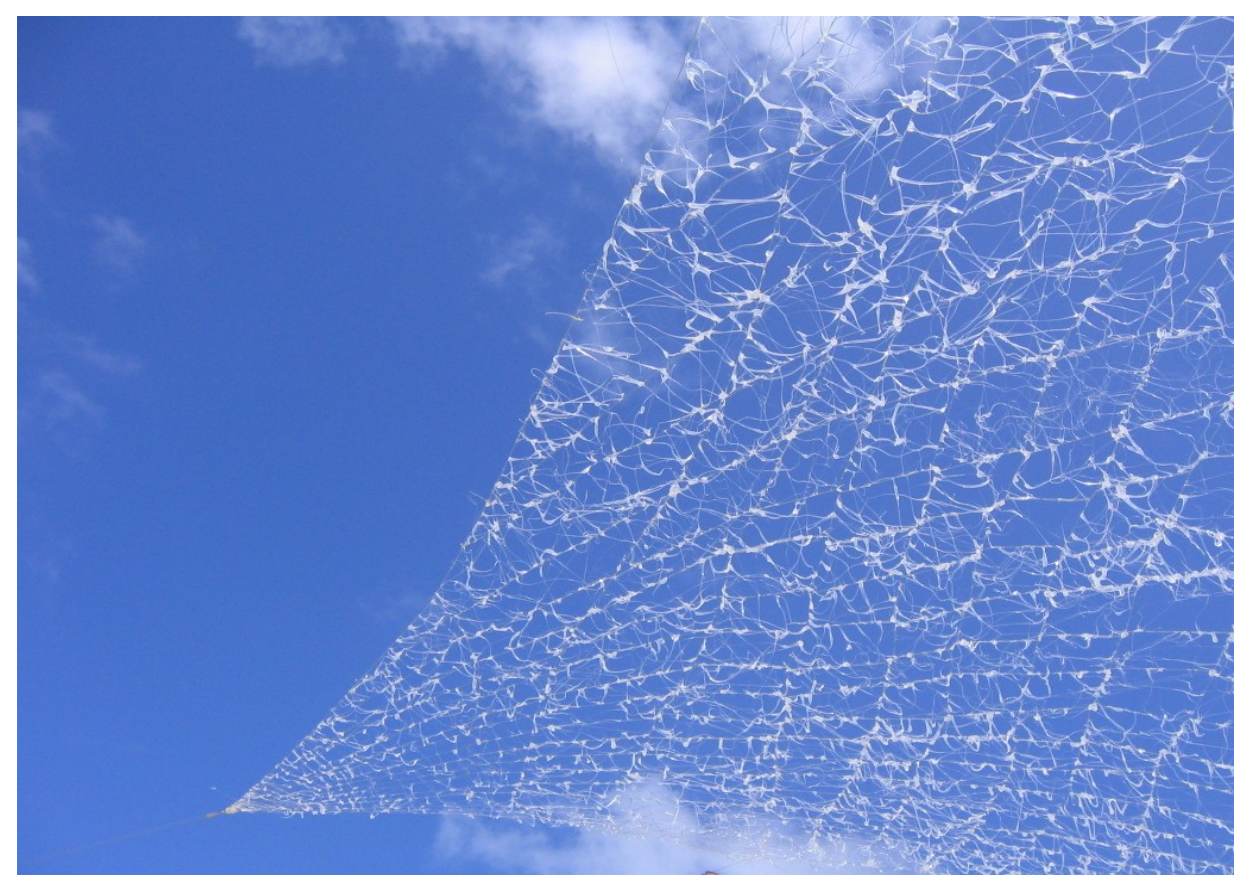

Figura 9 - Detalhe: imagem usada em projeto para sala expositiva, a seguir.

Fonte: A autora (2005) 


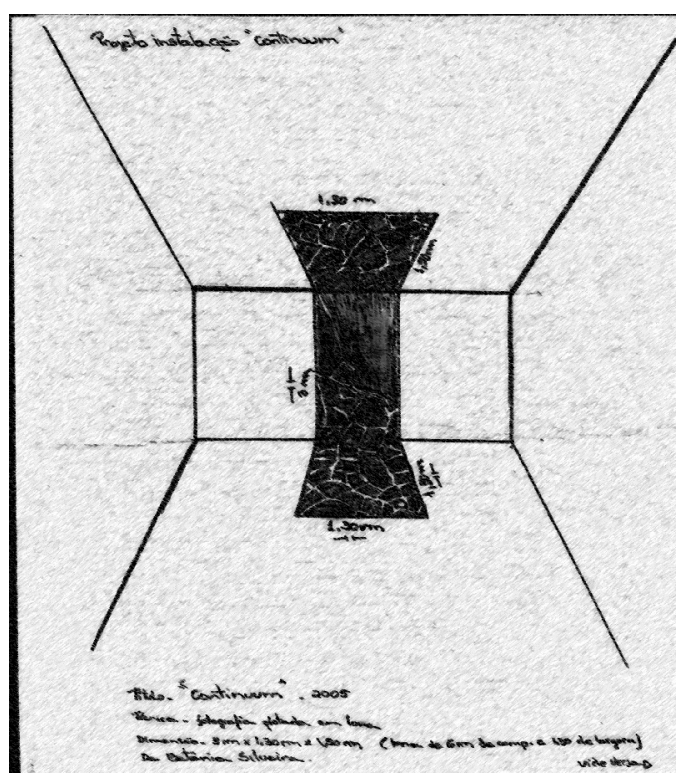

Figura 10 - "Continuum" - Projeto instalação. Betânia Silveira Florianópolis, SC. 2005. Dimensão: $3 \mathrm{~m} \times 1,30 \mathrm{~m} \times 1,50 \mathrm{~m}$.

Fonte: A autora, (2005)

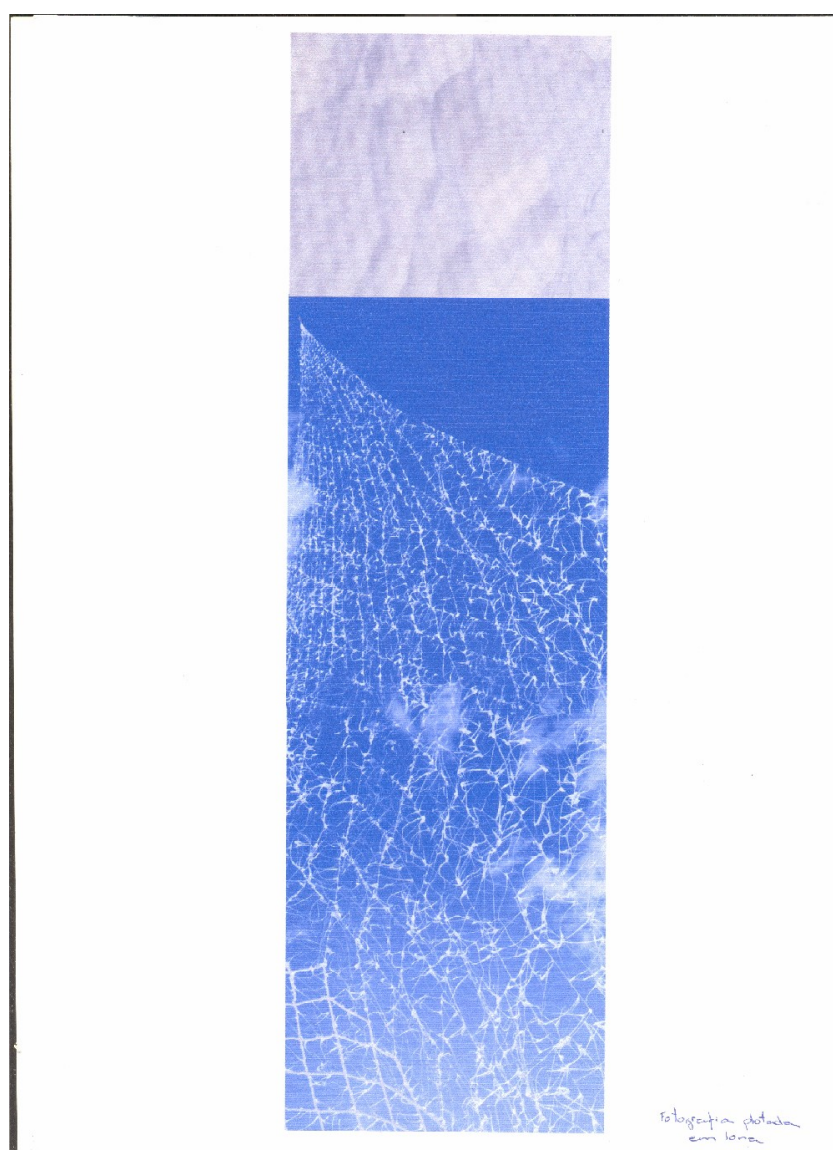

Figura 11 - Fotografia plotada em lona. Betânia Silveira. 2005.

Fonte: A autora (2005) 
Mesmo durante o período em que o silicone era mais veementemente usado como matéria expressiva para o trabalho poético em questão, nunca se interrompeu a produção da cerâmica. A idéia de rede tomava conta das reflexões vivenciadas e, ao mesmo tempo, o questionamento quanto à desvalorização e quanto ao uso cada vez menor da artesania na arte contemporânea levou a criação de uma série de mãos em gestos banais do cotidiano, a partir de uma forma de gesso tirada das próprias mãos.

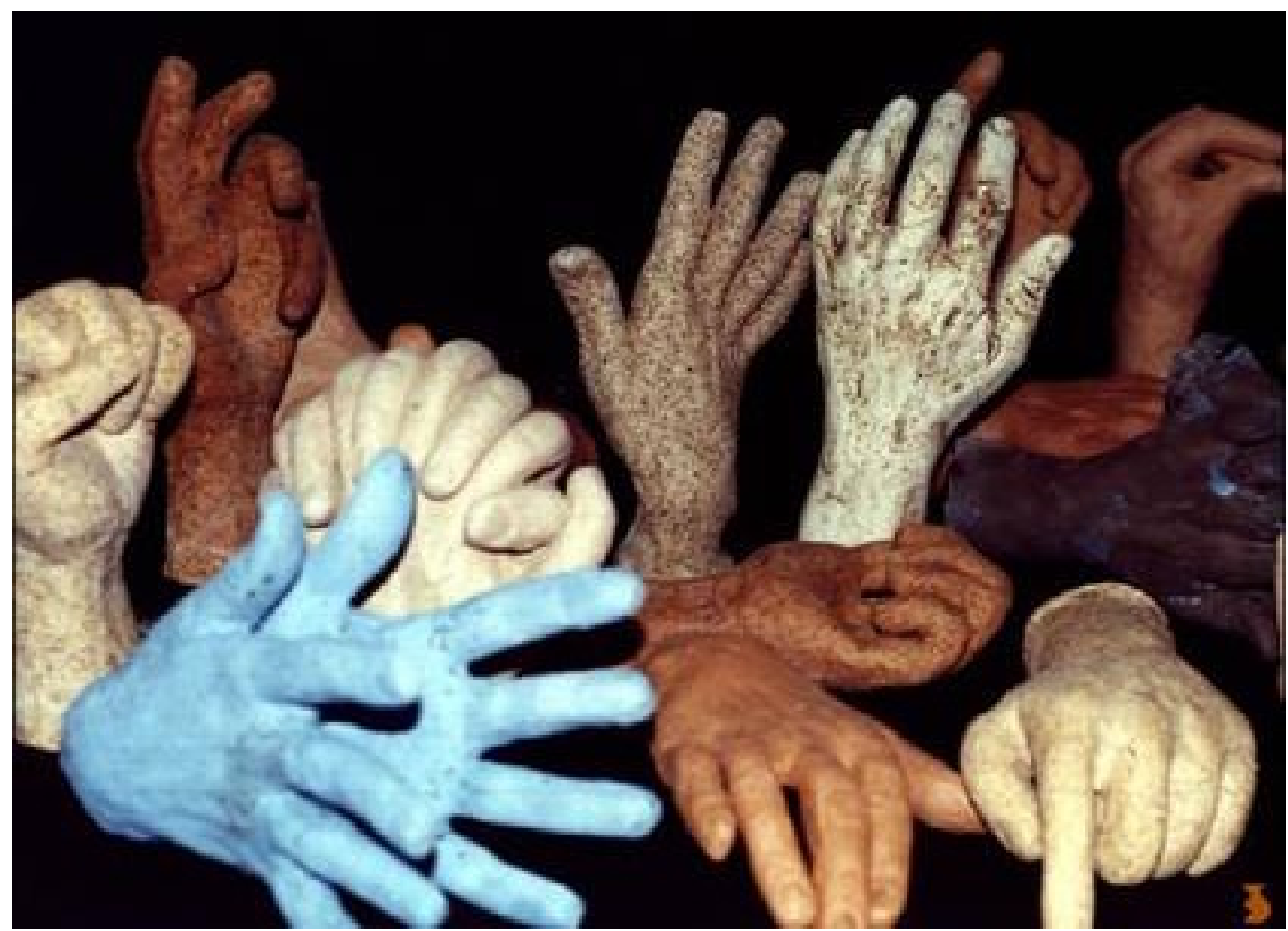

Figura 12 - Telúricas. Cerâmica ( massas coloridas e com metal). Betânia Silveira, 2001. Dimensão: Tamanho natural das mãos da autora.

Fonte: A autora (2001).

Em seguida, fragmentadas, as mãos de cerâmica deram lugar a uma grande coleção de dedos que juntos passaram a compor um painel interativo. Nele todas as digitais das pessoas que interagiam com o trabalho e determinavam novas composições formais, mesmo que invisíveis a olho nu, ali estavam e se sobrepunham umas as outras. Portanto, a cerâmica que junto ao silicone compunha trabalhos anteriores, reaparece 
em novas produções como suporte artístico principal e assim segue seu próprio curso nesta produção poética.

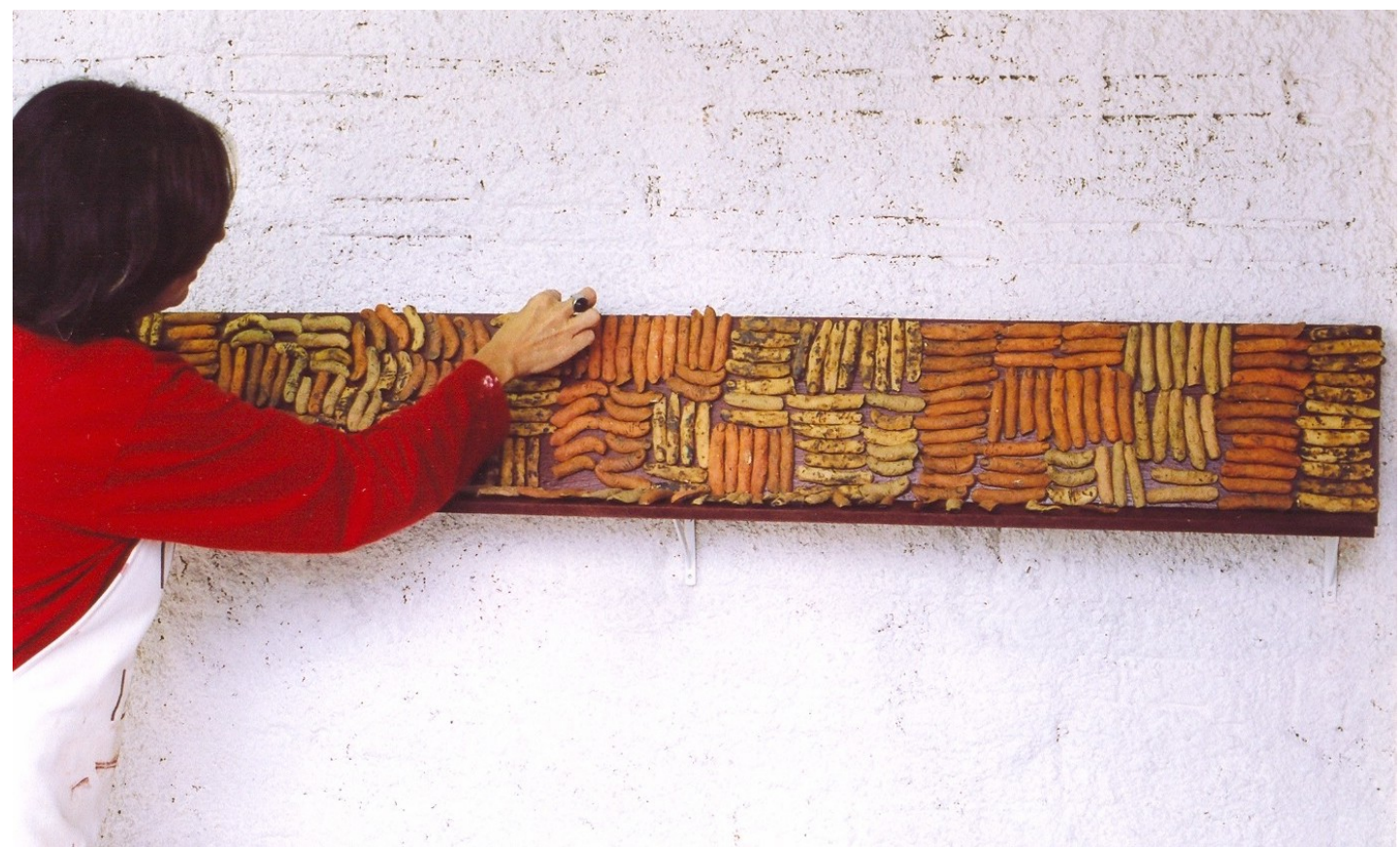

Figura 13 - Cerâmica Digital. Objeto interativo. Betânia Silveira, 2003/2004. Dimensão: $30 \mathrm{~cm} \times 150 \mathrm{~cm} \times 20 \mathrm{~cm}$.

Fonte: A autora (2004).

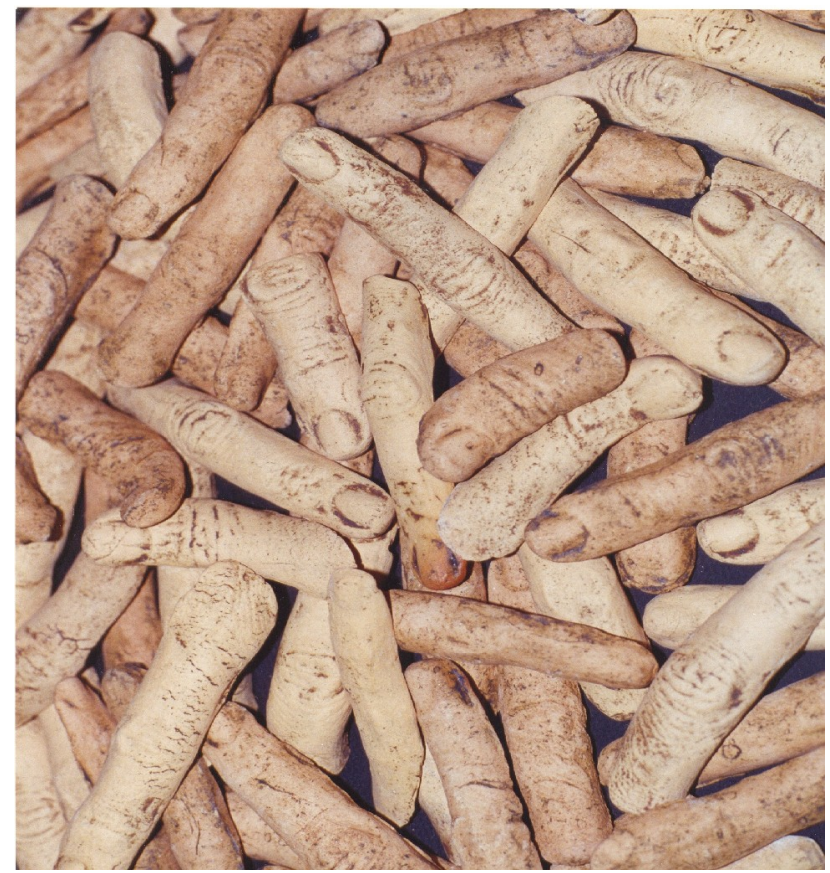

Figura 14 - Detalhe Objeto "Cerâmica Digital". (Massas c/ metal e temp. diversas). Dimensão real dos dedos da autora.

Fonte: A autora (2004). 
Pensar letras

Sentir palavras

A alma cheia de dedos.

(ALICE RUIZ)

\section{3 - TRAMANDO COM FIOS DE BARRO: PESQUISA E PROCESSO.}

Seguindo a indagações pessoais de caráter existencial, ao desejo de realizar antigos projetos de contribuir com o desdobramento do conhecimento da cerâmica expressiva e aos novos caminhos que se apresentava em 2003, o interesse pela cerâmica se vinculou à rede, desta vez a da hipermídia. Surge assim o desejo de desenvolver um $C D$ - ROM que abordasse a cerâmica em seus aspectos teóricos, técnicos e poéticos. Para isso uma nova pesquisa com o barro se fez necessário empreender na disciplina de mestrado, orientada pela professora Norma Grinberg, no início do segundo semestre de 2004.

A princípio se usou como conceito sustentador da pesquisa, a trama. Como se pode avaliar, a trama é sempre construtiva, estrutural, formadora de tecidos que podem constituir formas e texturas variadas. Uma trama sempre consolida uma história, quando nas mãos de um escritor; um ninho, quando construída pela natureza de um pássaro ou de um inseto em reprodução; um tecido quando nas mãos de Penélopes e Aracnes; uma rede quando nos reportamos à organização social e às formas de comunicação dos seres humanos, a realidade dos computadores e da hipermídia. Refere-se a esta realidade da qual se faz parte com o desenvolvimento deste $C D-R O M$, ao se trabalhar com esta multiplicidade de manifestações expressivas, materiais e profissionais.

Até mesmo a produção de uma obra de arte, segundo Salles (1998, p.36), resulta da construção de "uma trama complexa de propósitos e buscas: problemas, hipóteses, testagens, soluções e desencontros. Portanto, longe de linearidades, o que se percebe é uma rede de tendências que se inter-relacionam". 
$\mathrm{Na}$ trama da vida, como na rede da hipermídia, estabelecem-se relações e deslocamentos, possibilidades de transito, de cruzamentos de sentidos, sonhos e realidades factuais, de trocas de idéias, conhecimentos, sentimentos. Tratando especificamente dos sentimentos humanos, acrescenta Levy (2001, p.169), "na grande rede dos espíritos interconectados, o medo, o ódio, o amor, a alegria, a beleza e a feiúra circulam e se propagam por todos os atos visíveis ou invisíveis que perfazemos".

Na busca sonhada de dizer o que se pensa sem usar das palavras, com fios de barro, produziu-se um tipo de trama, tecido que se petrificou com a ação das queimas, resultando em frágeis estruturas de cerâmica branca. No nosso entender, esta imagem cerâmica alude não só as interconexões, mas também aos seus rompimentos, como na vida, tecido cujos fios podem se romper em um simples trocar de minutos, e na rede da internet onde muitas vezes sites e links deixam de existir.

Pela fragilidade dos fios de cerâmica, as quebras constantes produziram muitos fragmentos. Estes participaram da construção de novas tramas montadas, num segundo momento. Assim o trabalho e seu processo continuavam... Evidencia-se neste fato um estreito relacionar-se com o acaso. Abarcar o acaso na produção de obras de arte é bastante recorrente e comum ao percurso de todo artista. Como aborda Pareyson (1993) uma obra de arte é feita pelo artista em diálogo com a matéria, esta também indica caminhos a seguir.

\footnotetext{
"Assim, pode-se mesmo dizer que o processo artístico é aquele em que o intuito de quem o faz é pôr-se no ponto de vista da obra que ele vai fazendo, e só se ele consegue colocar-se nesse ponto de vista é que a obra vai bem e termina com sucesso". (PAREYSON, 1993, p.79)
}

Arché (2001) comenta que a atitude de absorver o acaso nas obras de arte não só reflete uma herança do Dadaísmo, mas indica também o reconhecimento de que na vida as coisas simplesmente acontecem. Para Ostrower (1987) na liberdade que temos ao longo do nosso processo de criação utilizamos os acasos e os convertemos em nossos, isto é, fazemos com que deixem de ser acasos para tornarem-se escolhas 
conscientes, assim, pertencendo-nos passam a ser novas possibilidades de transformação.

Existe um termo oriundo da língua inglesa, serendity, serendipidade em português, que diz respeito ao dom ou aptidão para atrair o acontecimento de coisas felizes ou úteis ou, mesmo, de descobri-las por acaso. Esta característica envolve de forma decisiva a produção do trabalho que ganhou o nome de "Ítalo, Valeska, o Pássaro e Eu" (selecionado em 2006 para o Salão Nacional de Cerâmica em Curitiba, PR), tratado mais adiante com maiores detalhes.

De pura serendipidade foi o encontro dos ninhos de pássaros tramados com gravetos que, mais tarde, foram transformados em cerâmica. Acaso que nos remete a Celeida Tostes, artista plástica carioca, atuante até a década de noventa, que ao encontrar um ninho de João de Barro deu início a um longo trajeto poético e plástico com o barro, para falar do homem, suas formas de organização social, suas habitações. Nesta fase a artista realiza, também, contundente performance, metáfora do retorno ao ventre da terra para expressar sentimentos tão femininos do gestar e do nascer.

Indagando como tramar com o barro, deu-se início, então, a uma rica experimentação com a argila. O processo demonstrou exigir um limite de tensão do material para realizar a construção de novas possibilidades de formas e texturas que, posteriormente, consolidaram-se em um corpo cerâmico branco, frágil e curioso.

No primeiro momento da pesquisa se buscou associar o barro a diversos materiais tais como: telas metálicas, fios de aço, fibras vegetais, cordão de algodão e ninhos estruturados por pássaros, pequenos objetos trouvées dos meus caminhos cotidianos. Obtendo resultados satisfatórios com os três últimos, deu-se prosseguimento ao trabalho. 
O processo constituiu-se, primeiramente, em embeber na argila líquida e densa, a barbotina, o cordão de algodão, as fibras vegetais (sisal, palha e rama de coqueiro), assim como os ninhos que foram encontrados abandonados. Em seguida, para o caso dos fios e fibras, utilizou-se de estruturas feitas com papel jornal, placas e moldes de gesso, para produzir volumes e texturas com o ziguezaguear das linhas, que se entrecruzavam caoticamente, dando vazão ao gesto construtivo e, conseqüentemente, a uma trama nada regular, nem um pouco racional, caracterizando uma "escritura" pessoal.

Depois desta etapa, era necessário deixar secar um pouco a argila para que fosse possível aplicar, com pincel grosso, outras demãos da barbotina sobre a trama que se estruturava em objetos volumétricos, outras vezes laminares, como palimpsesto cuja seqüência de camadas recobertas esconde e engrossa a anterior.

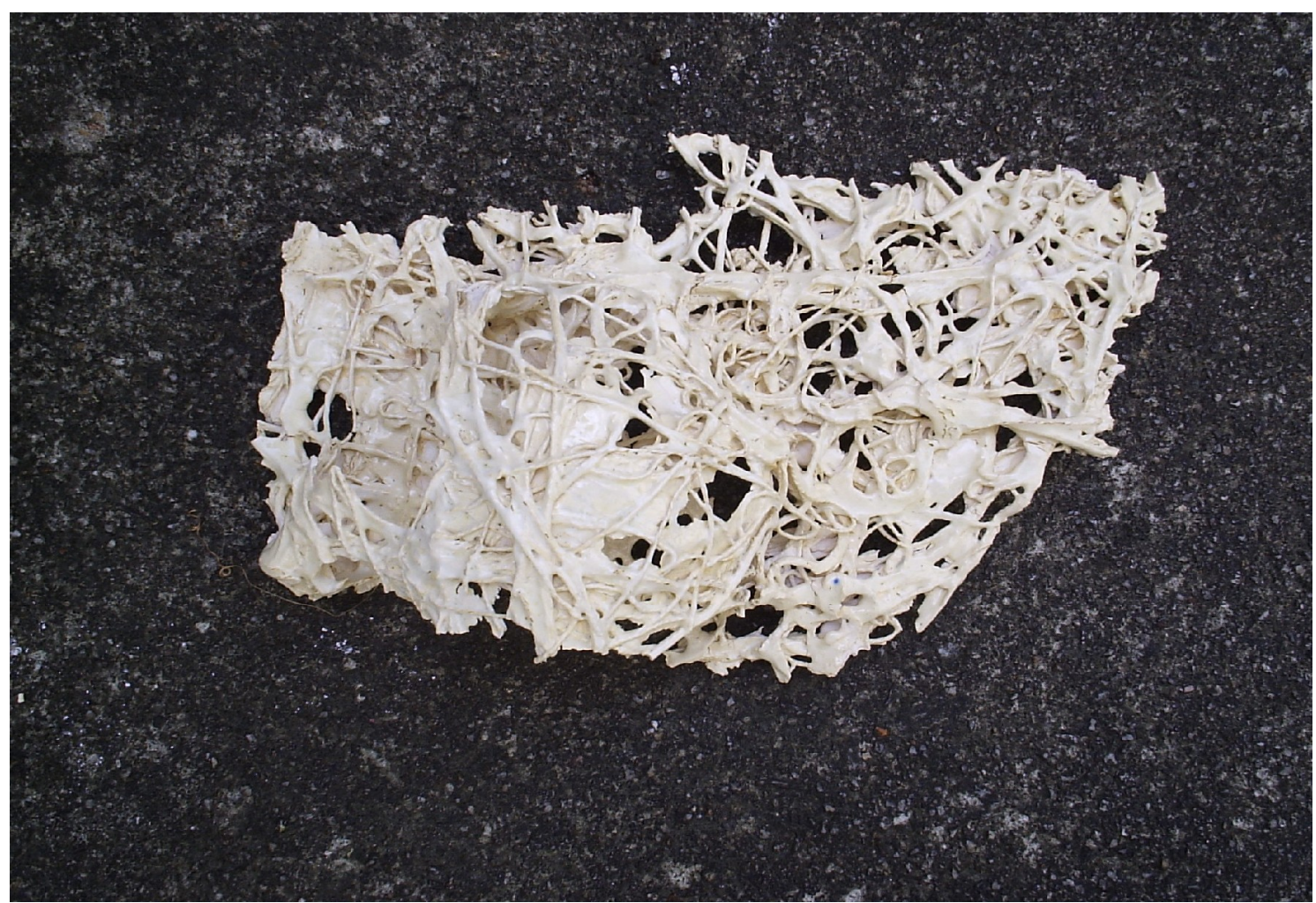

Figura 15 - Cordão fino de algodão sobre placa de gesso. Betânia Silveira, São Paulo, 2004. Dimensão: $10 \mathrm{~cm} \times 35 \mathrm{~cm} \times 25 \mathrm{~cm}$.

Fonte: A autora (2004) 


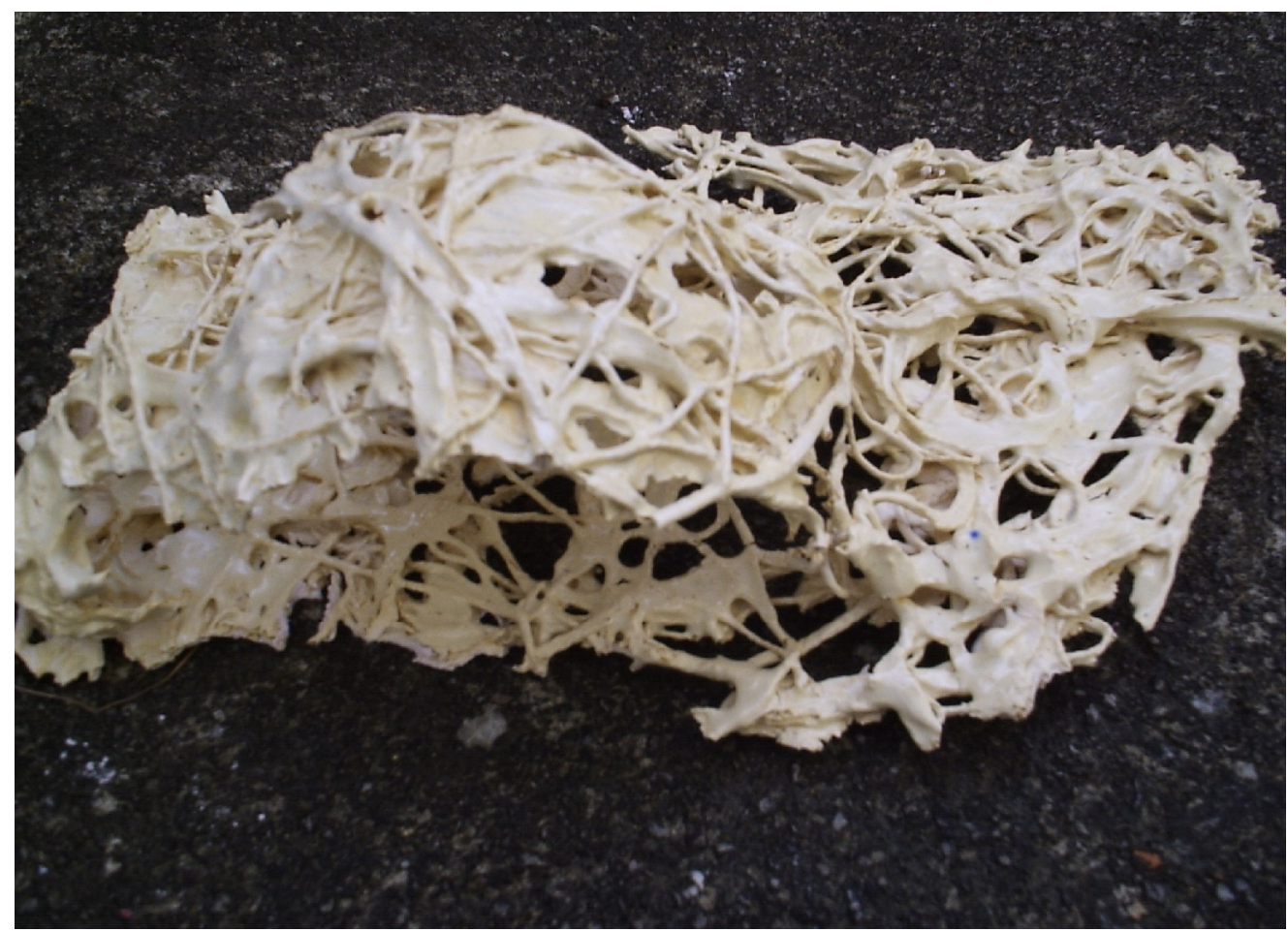

Figura 16 - cordão fino de algodão sobre placa de gesso associada a forma convexa.

Vista lateral do objeto anterior. Dimensão: $10 \mathrm{~cm} \times 35 \mathrm{~cm}$ X $25 \mathrm{~cm}$.

Fonte: A autora (2005).

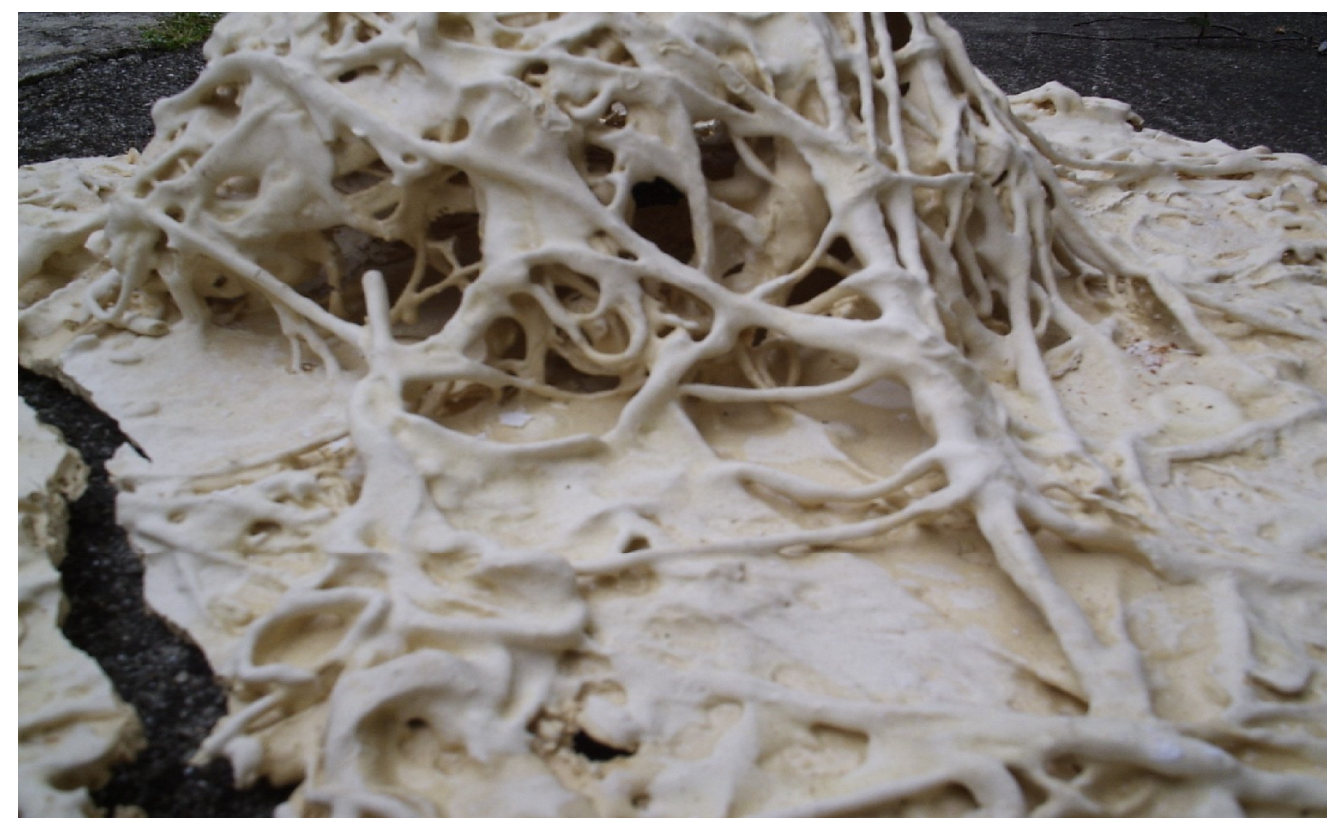

Figura 17 - cordão grosso de algodão sobre placa cindida com forma convexa. Betânia Silveira, São Paulo, 2004. Dimensão: $15 \mathrm{~cm}$ X 50cm X 40cm.

Fonte : A autora (2005) 


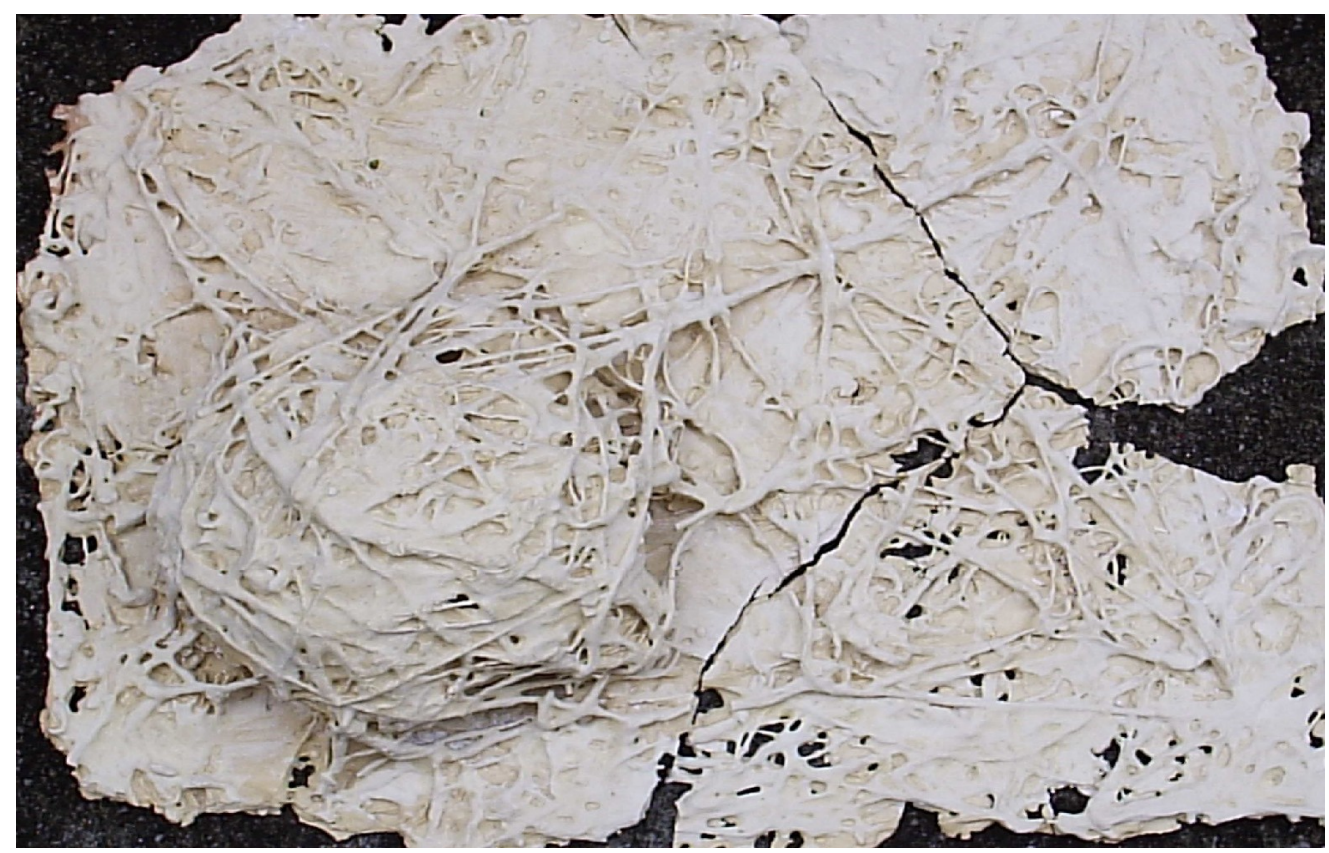

Figura 18 - cordão grosso de algodão sobre placa cindida com forma convexa. Vista de cima. Fonte: A autora (2006).

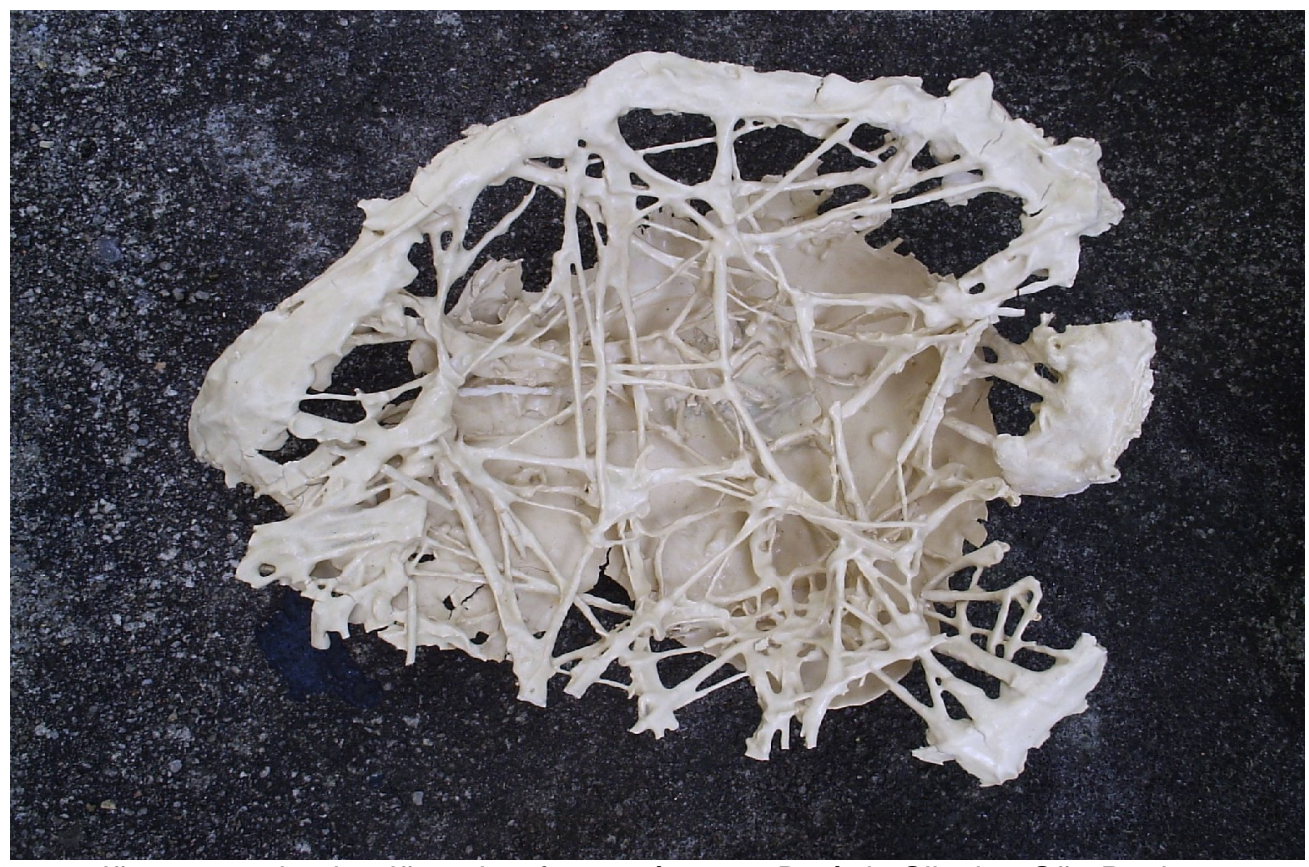

Figura 19 - cordão grosso de algodão sobre forma côncava. Betânia Silveira, São Paulo, 2004. Dimensão: $20 \mathrm{~cm} \times 35 \mathrm{~cm}$ X $40 \mathrm{~cm}$.

Fonte: A autora (2005). 


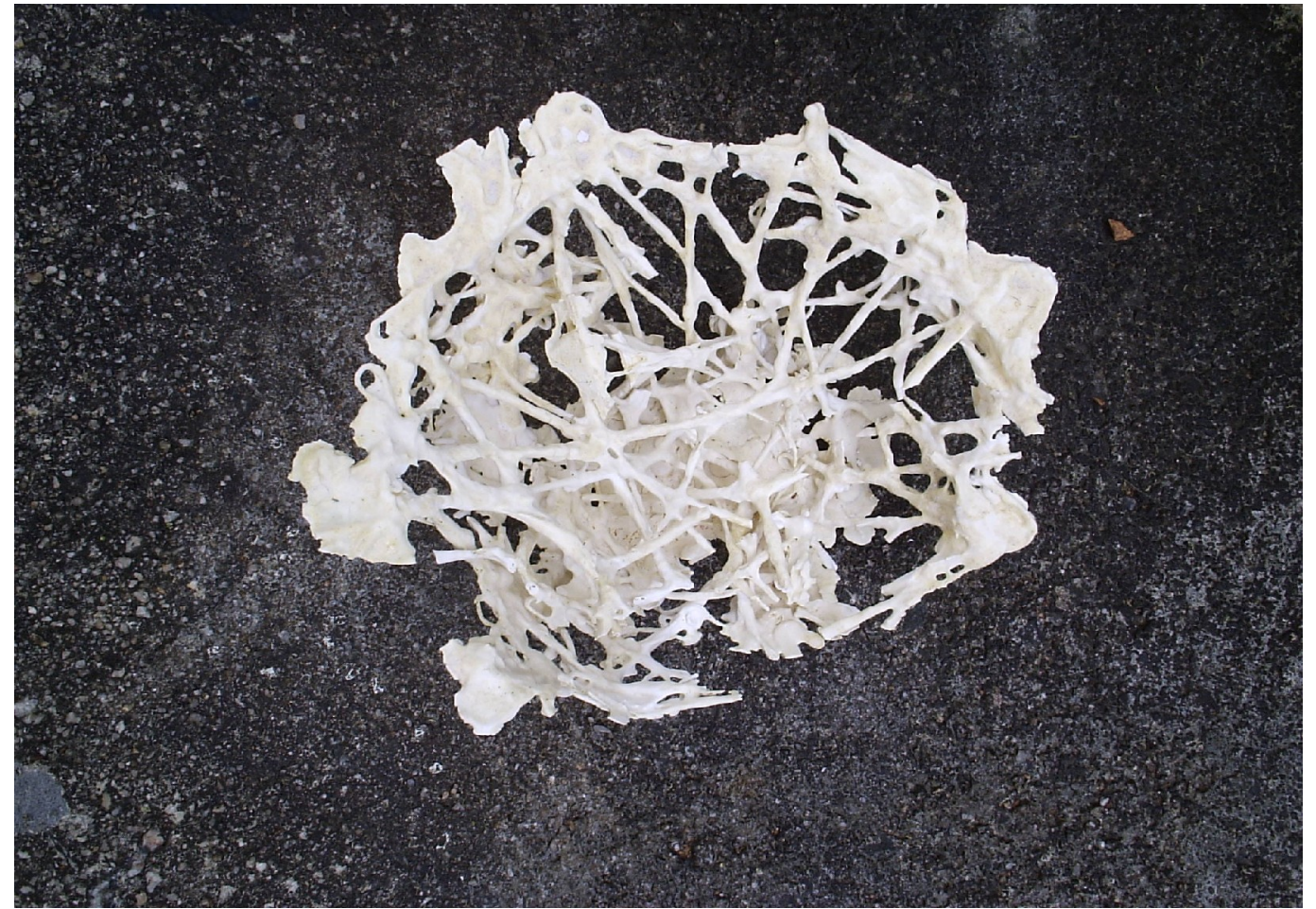

Figura 20 - algodão grosso em forma de gesso côncava. Betânia Silveira, São Paulo, 2004. Dimensão: $18 \mathrm{~cm} \times 25 \mathrm{~cm} \times 20 \mathrm{~cm}$.

Fonte: A autora (2005).

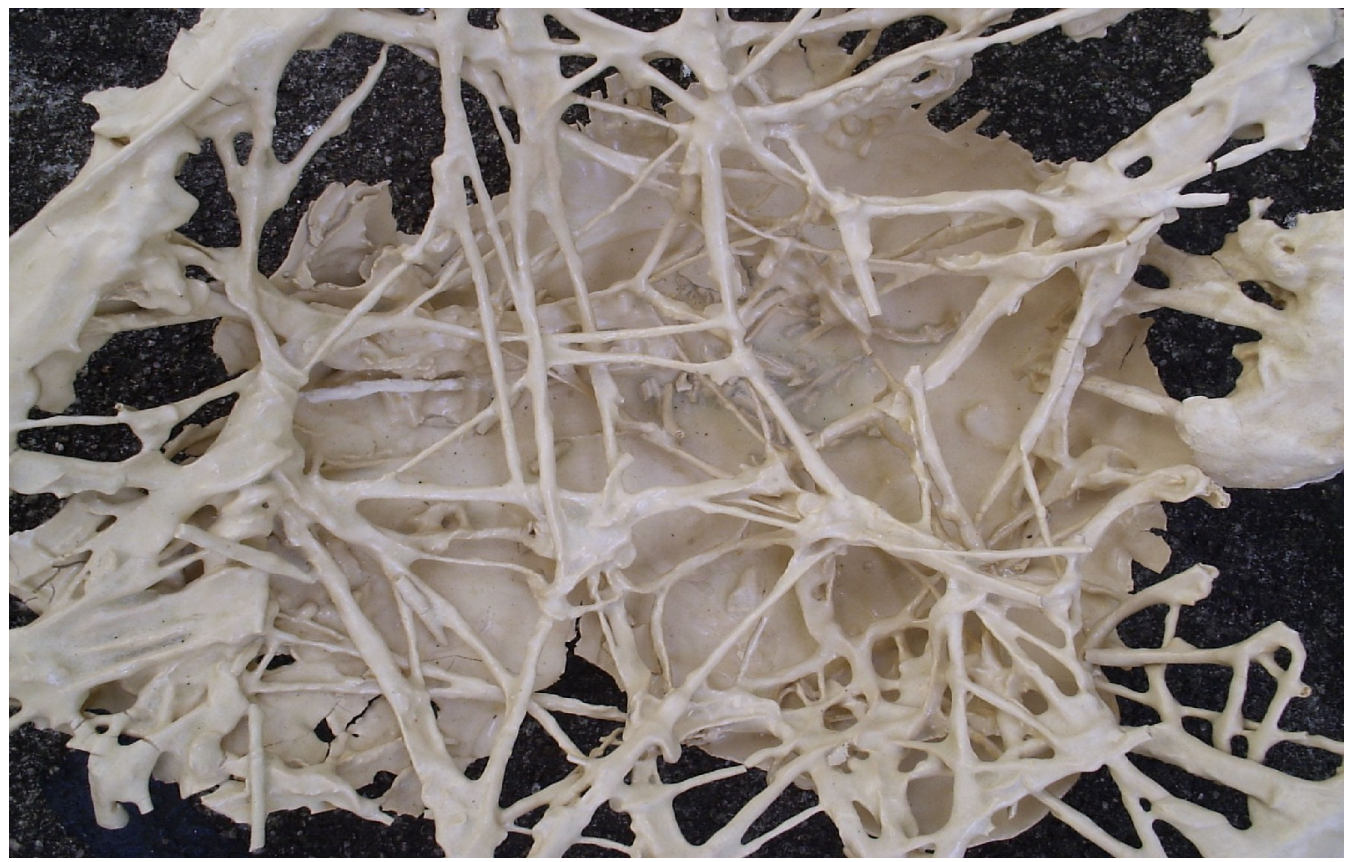

Figura 21 - algodão grosso em forma de gesso côncava. Detalhe do objeto da figura anterior. Fonte: A autora (2005). 


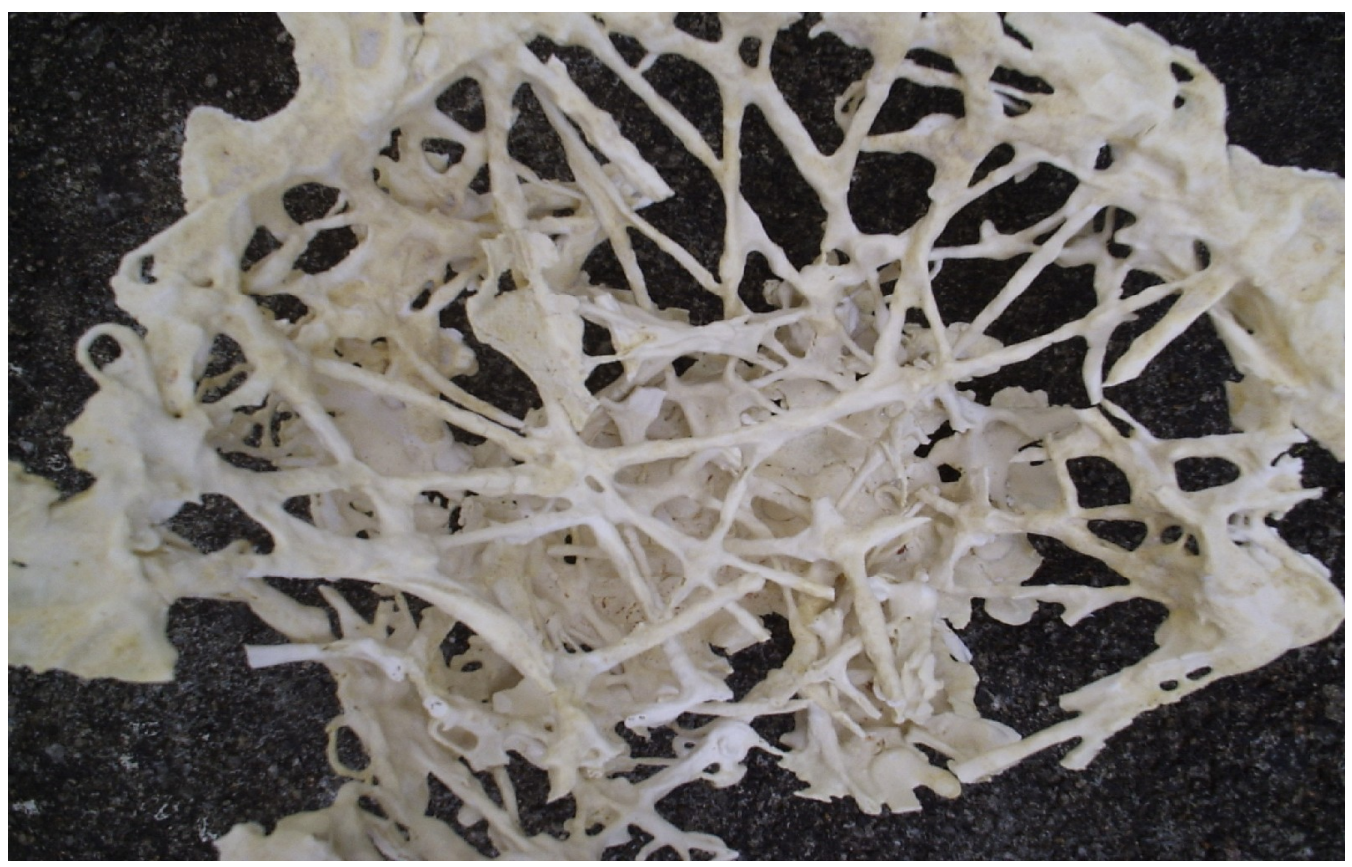

Figura 22 - algodão grosso em forma de gesso côncava. Detalhe.

Fonte: A autora (2005).

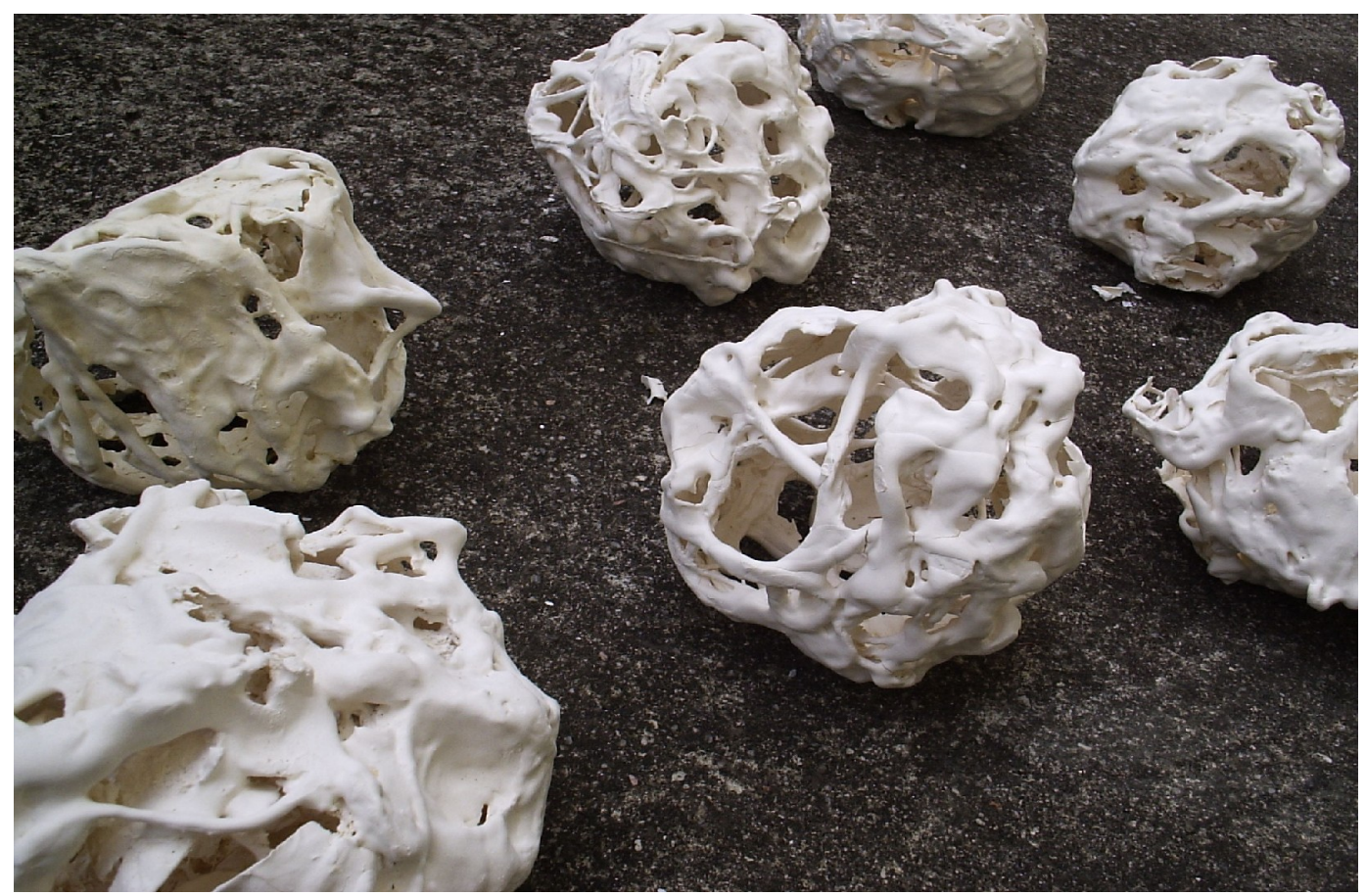

Figura 23 - Cordão grosso de algodão embebido de barbotina sobre bolas de papel jornal. Betânia Silveira, São Paulo, 2004. Dimensão: $13 \mathrm{~cm}$ X $14 \mathrm{~cm} \mathrm{X} 13 \mathrm{~cm}$.

Fonte: A autora (2005). 
Os objetos da imagem acima, levados ao forno elétrico a $1050^{\circ} \mathrm{C}$, foram produzidos com o cordão embebido na barbotina, tramado sobre bolas de papel jornal que, conseqüentemente, se desmaterializaram com a ação do calor.

Para as ramas de coqueiro, pincelou-se com o barro liquido sua estrutura, inúmeras e incontáveis vezes. Estas geraram fragmentos muito interessantes, partes componentes de um aglomerado, posteriormente, unidas por fio de náilon como se vê na figura abaixo.

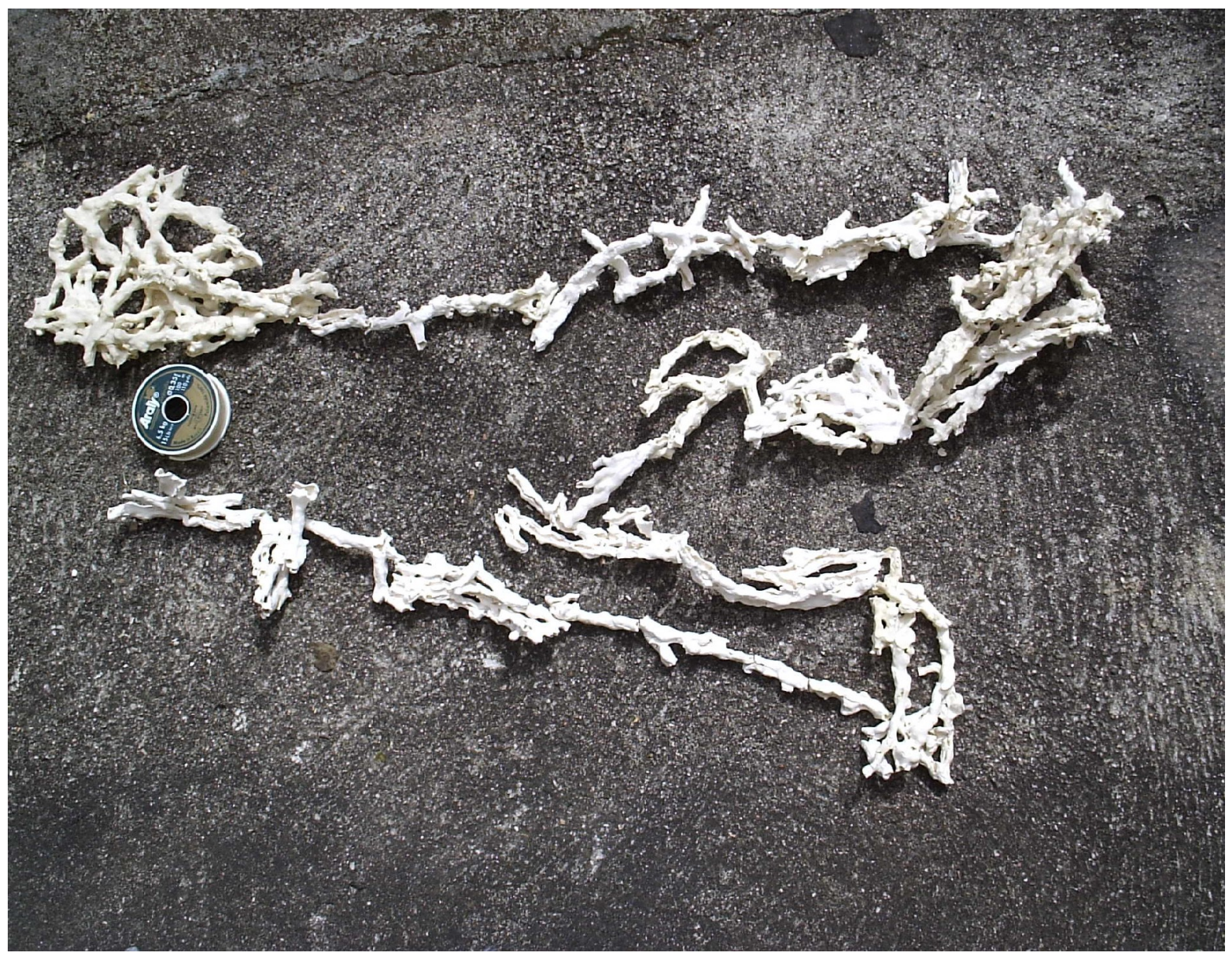

Figura 24 - Fragmentos de cerâmica feitos com ramas de coqueiro recobertas de barbotina e unidos por náilon. Imagem do processo. Betânia Silveira, São Paulo, 2004.

Fonte: A autora (2005). 


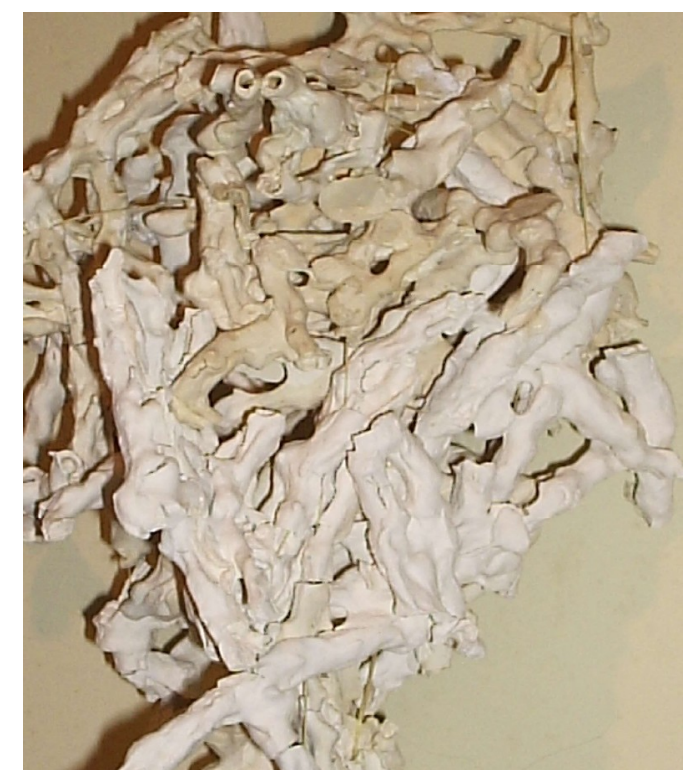

Figura 25 - Detalhe do objeto da imagem anterior. Dimensão: $70 \mathrm{~cm} \times 30 \mathrm{~cm} \times 25 \mathrm{~cm}$. Fonte: A autora (2005).

No caso dos ninhos, a experiência mostrou que aqueles produzidos com gravetos suportavam melhor o peso da argila e mantinham suas estruturas originais, enquanto os constituídos com fibras macias perdiam suas formas primeiras e com elas seus aspectos de maciez e conforto, portanto suas identidades.

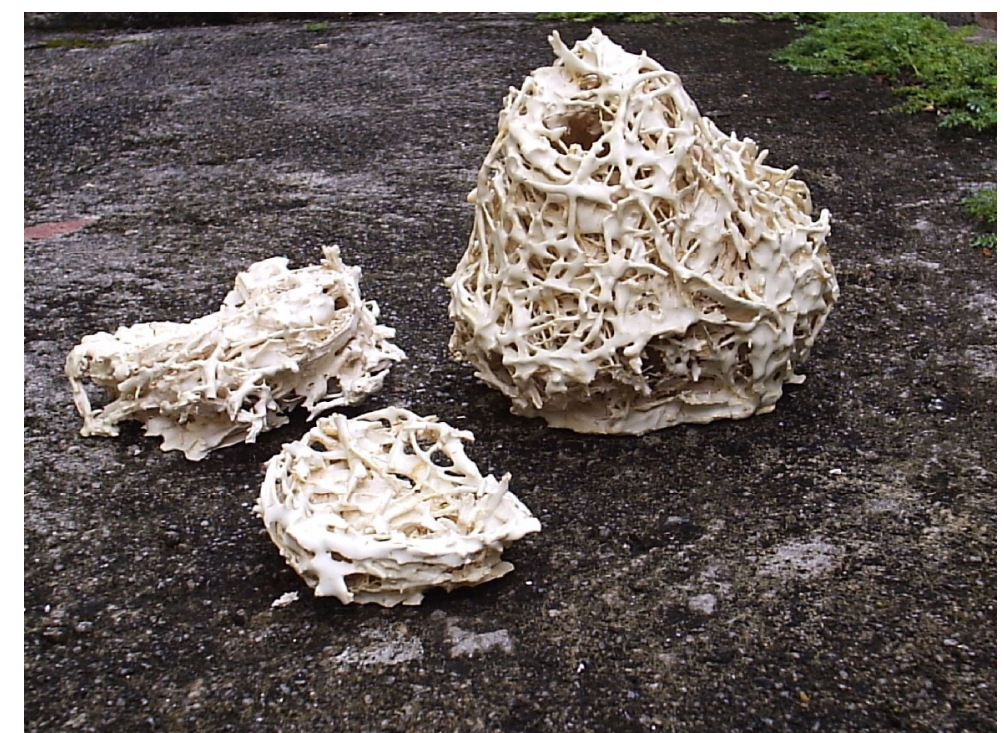

Figuras 26 - Cerâmicas feitas com ninhos de gravetos recobertos com barbotina. Betânia Silveira, Florianópolis, SC. 2004. Dimensões: $15 \mathrm{~cm} \mathrm{X} 13 \mathrm{~cm} \mathrm{X} \mathrm{15cm} \mathrm{(obj.} \mathrm{maior);} 3,5 \mathrm{~cm} \times 8 \mathrm{~cm} \mathrm{X} 10 \mathrm{~cm}$ (menor). Fonte: A autora (2005). 


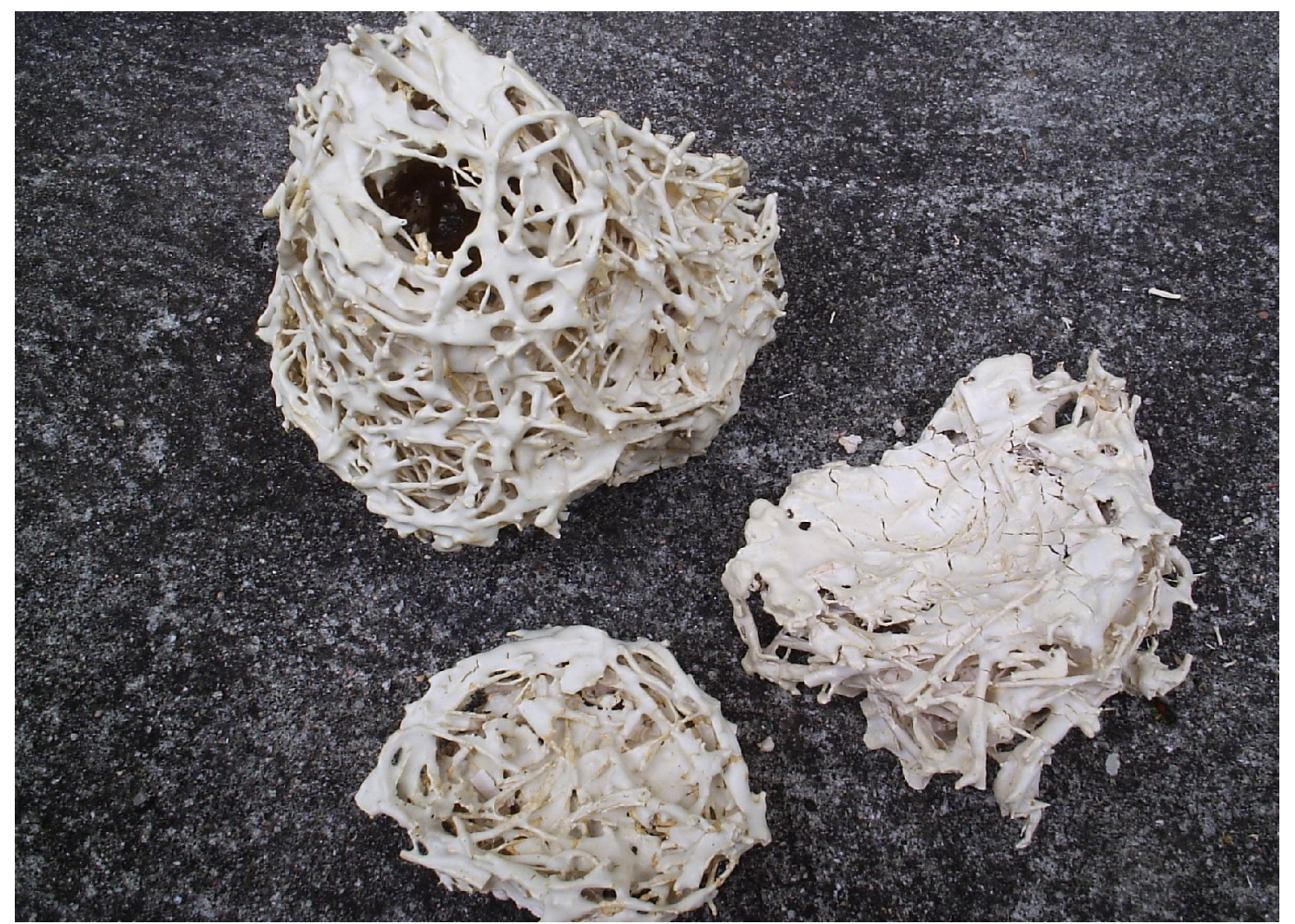

Figuras 27 - Cerâmicas feitas com ninhos de gravetos recobertos com barbotina. Betânia Silveira, Florianópolis, SC. 2004.

Fonte: A autora (2005).

Estes ninhos, agora de cerâmica, foram associados a caixas de vidro cuja parte superior foi montada com fragmentos de espelho impresso, reaproveitamento de uma obra quebrada de Valeska Soares com texto de Ítalo Calvino. Este trabalho reflete, mais uma vez, o interesse por outras conexões, por tramar vários "sonhos" numa única expressão. Nesse sentido, podemos observar uma relação estreita, metafórica e também de propósitos, com o CD-ROM que aqui se apresenta como resultado final desta dissertação de mestrado. Em "Ítalo, Valeska, o Pássaro e Eu", também, se encontra uma autoria diluída e uma conexão de sentidos, características próprias do $C D$ em questão. 


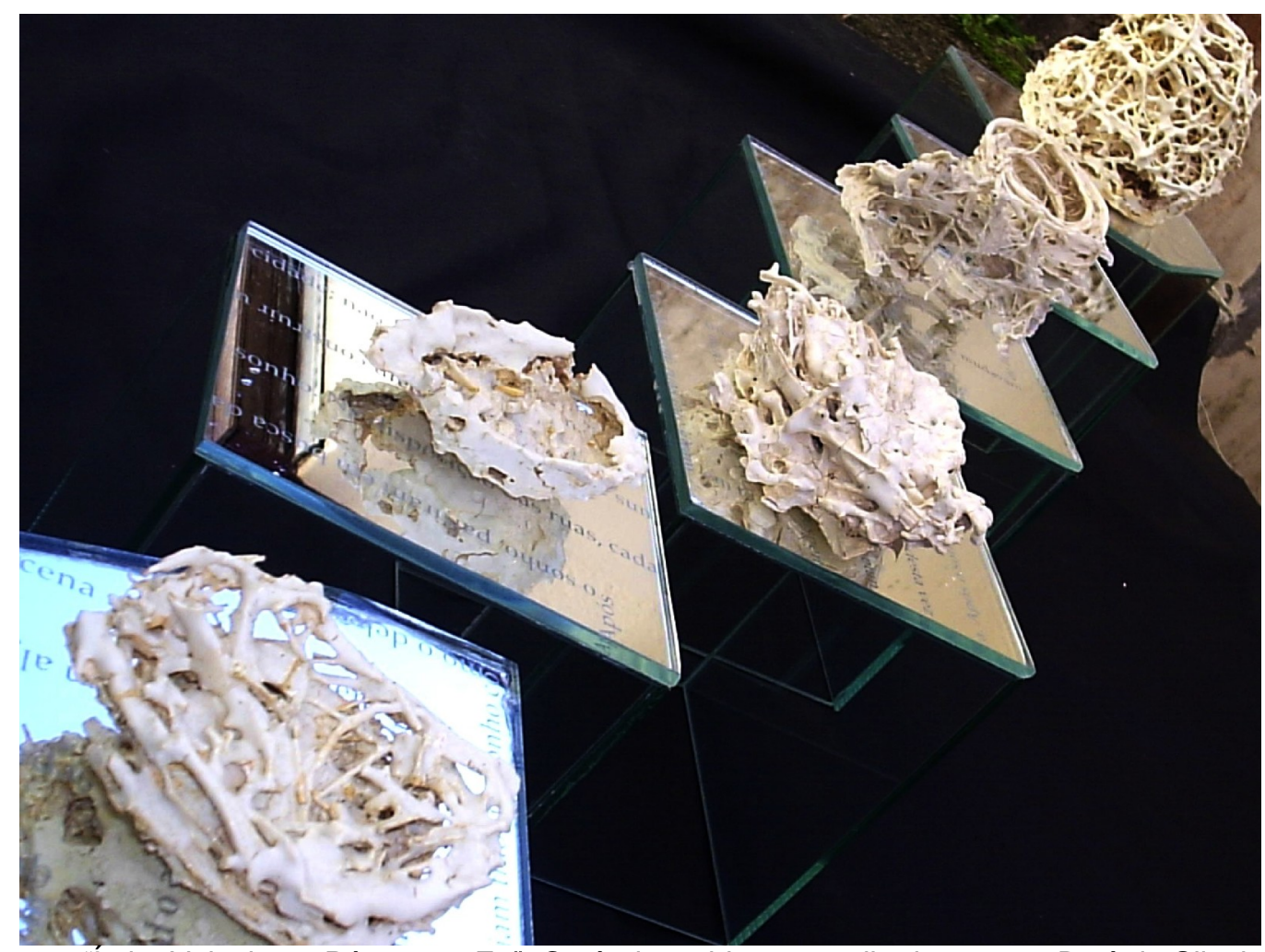

Figura 28 - "Italo, Valeska, o Pássaro e Eu". Cerâmica, vidro e espelho impresso. Betânia Silveira. Salão Nacional de Cerâmica, Curitiba, PR, 2006. Dimensão: área de $31 \mathrm{~cm} \mathrm{X} \mathrm{250cm} \mathrm{X} 150 \mathrm{~cm}$.

Fonte: A autora (2006).

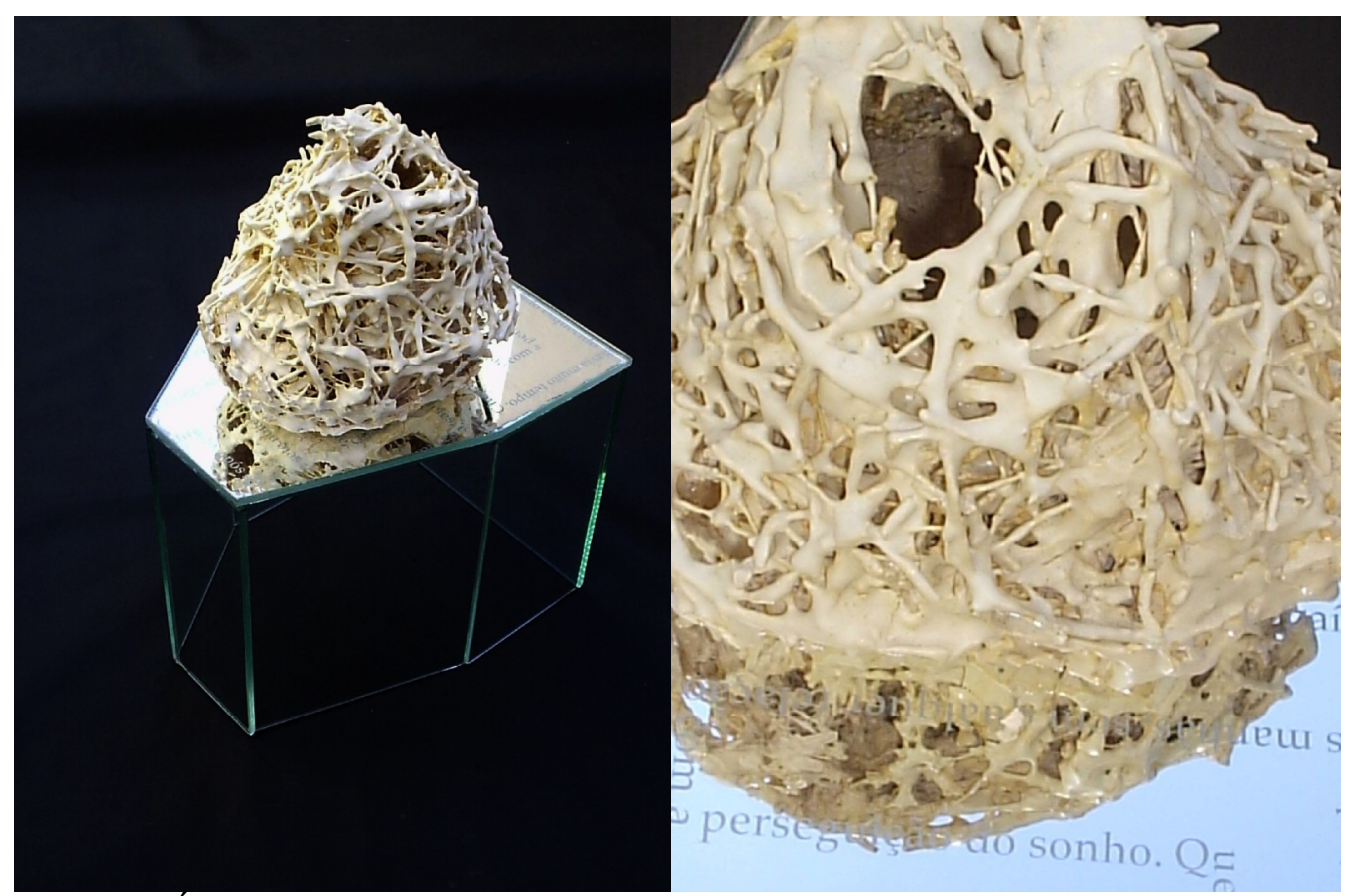

Figura - 29 - 30 - "Italo, Valeska, o Pássaro e Eu". Detalhes. Dimensão: $31 \mathrm{~cm} \mathrm{X} \mathrm{20cm} \mathrm{X} \mathrm{20cm.}$ Fonte: A autora (2006). 


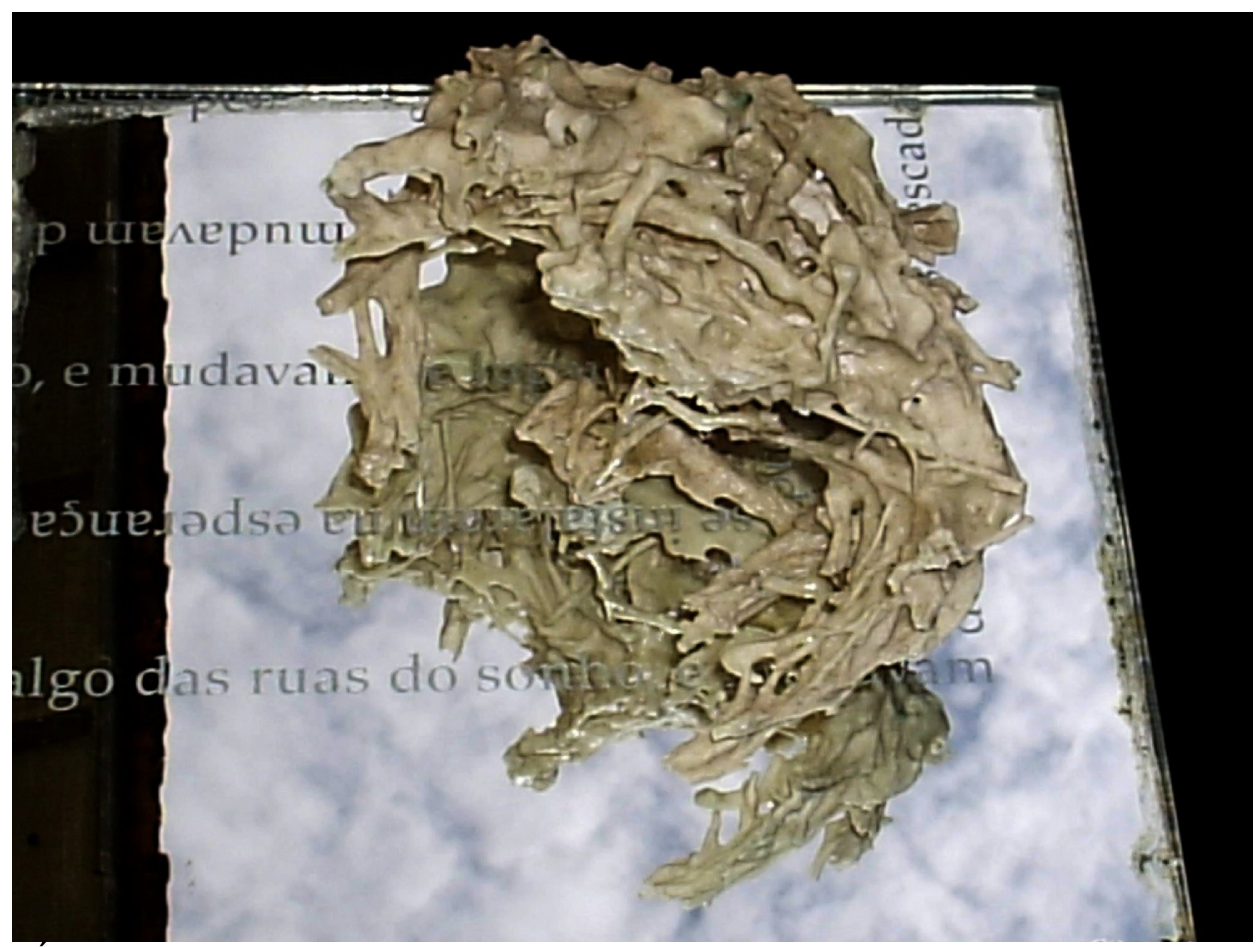

Figura 31 - "Italo, Valeska, o Pássaro e Eu". Detalhe. Dimensão: $22 \mathrm{~cm} \mathrm{X} 15 \mathrm{~cm} \mathrm{X} 15 \mathrm{~cm}$. Fonte: A autora (2006).

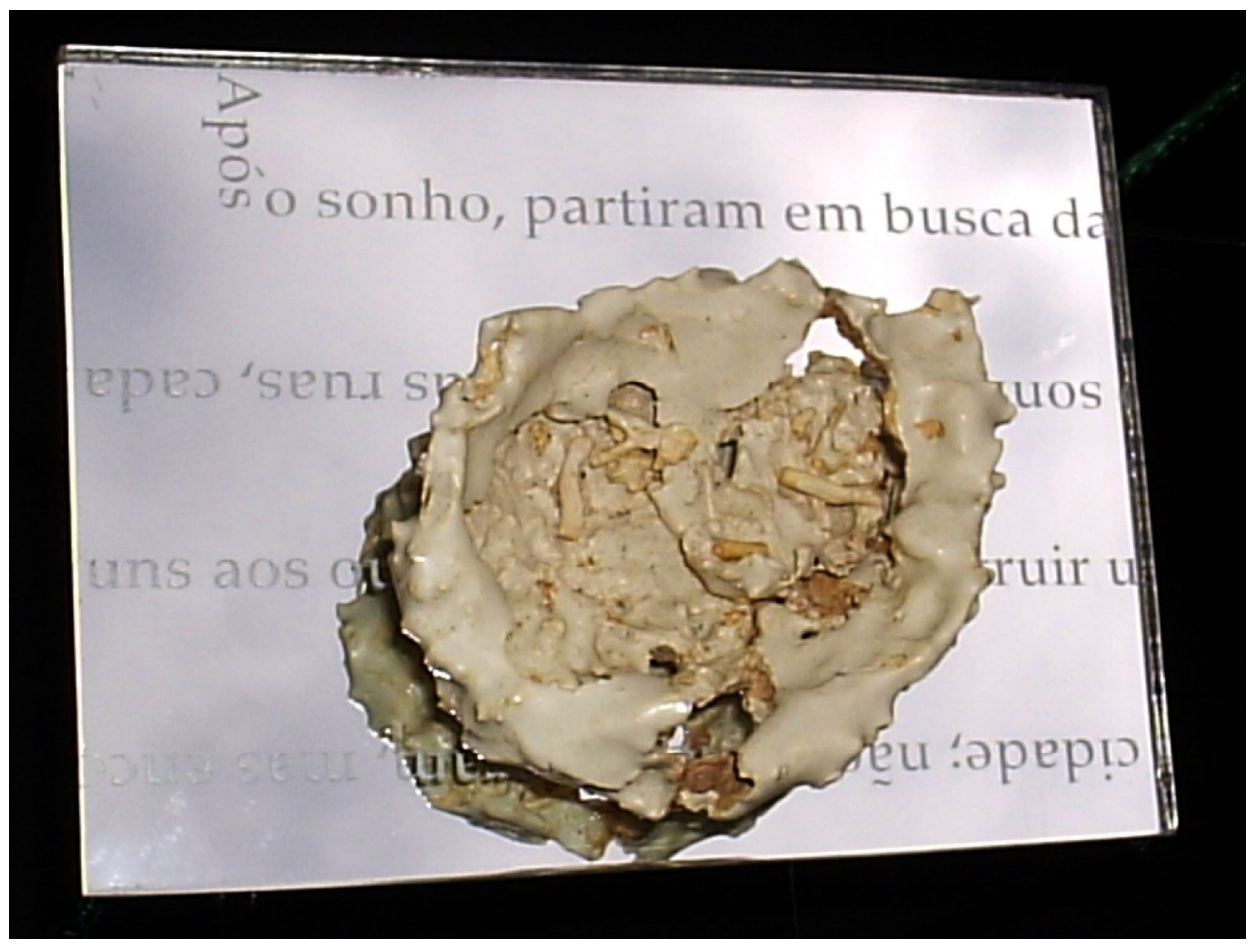

Figura 32 - "Ítalo, Valeska, o Pássaro e Eu". Detalhe. Dimensão: $19 \mathrm{~cm}$ X $10 \mathrm{~cm}$ X $15 \mathrm{~cm}$. Fonte: A autora (2006). 
Decidiu-se, posteriormente, usar puros fios de argila obtidos apenas com a extrusão do barro por meio de uma ferramenta própria, parecida com os amassadores de alho ou batatas, usados na cozinha. Deixou-se que estes fios se acumulassem para em seguida serem pressionados levemente, no sentido de se obter pequenas esferas do tamanho de bolas de tênis. Recortou-se estes volumes para revelar seu interior e produzir objetos lúdicos que podem ser montados e desmontados. Por último, com esta mesma técnica, construiu-se outro objeto que não recebeu nenhum tipo de pressão, mantendo os fios como iam se depositando.

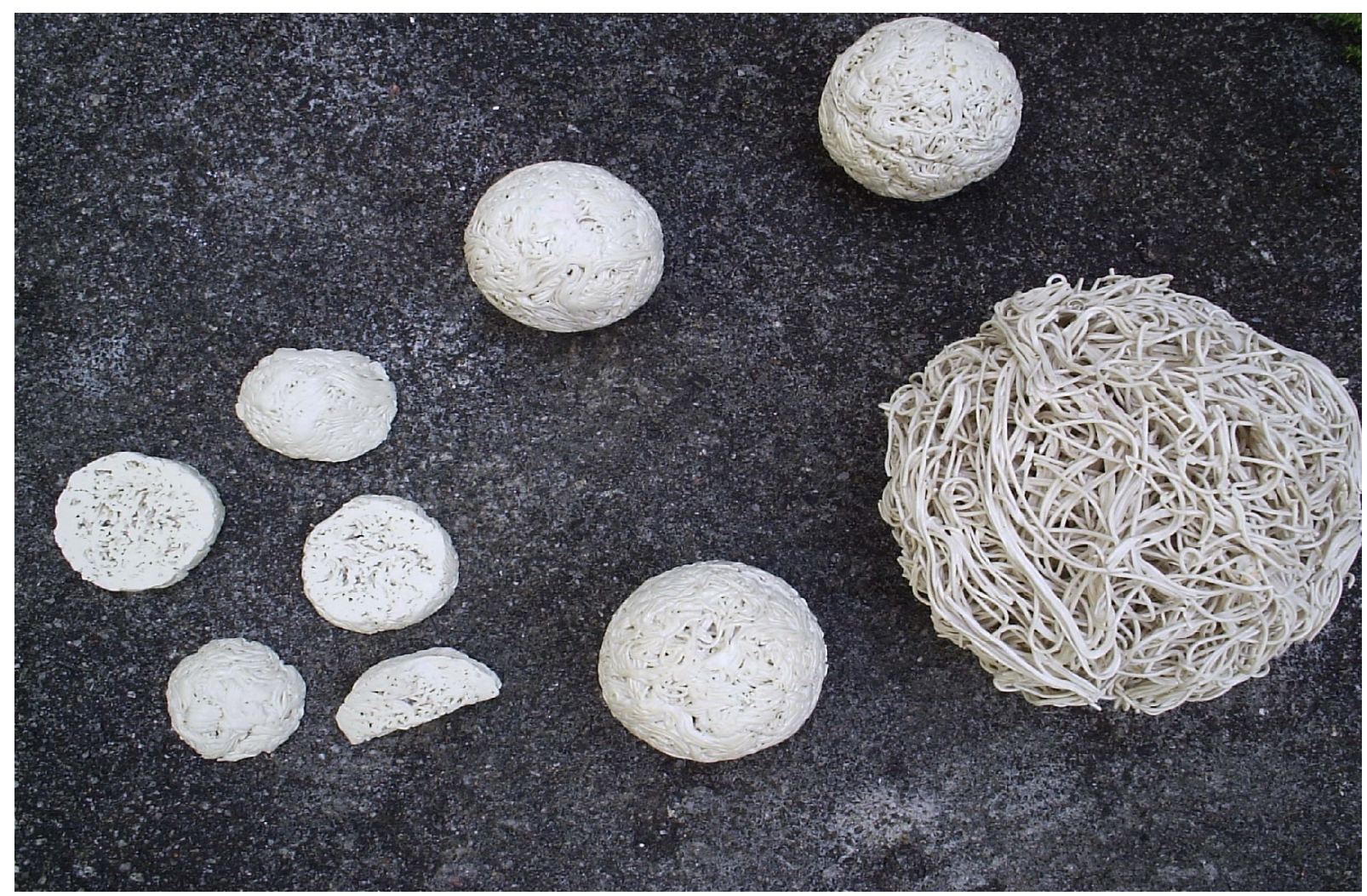

Figura 33 - Cerâmica com fios feitos por compressor manual. Betânia Silveira, Florianópolis, 2004. Dimensões: $20 \mathrm{~cm} \mathrm{X} 18 \mathrm{~cm}$ X 20cm (obj. maior); $12 \mathrm{~cm} \mathrm{X} \mathrm{12cm} \mathrm{X} \mathrm{12cm} \mathrm{(menores).}$

Fonte: A autora (2005). 


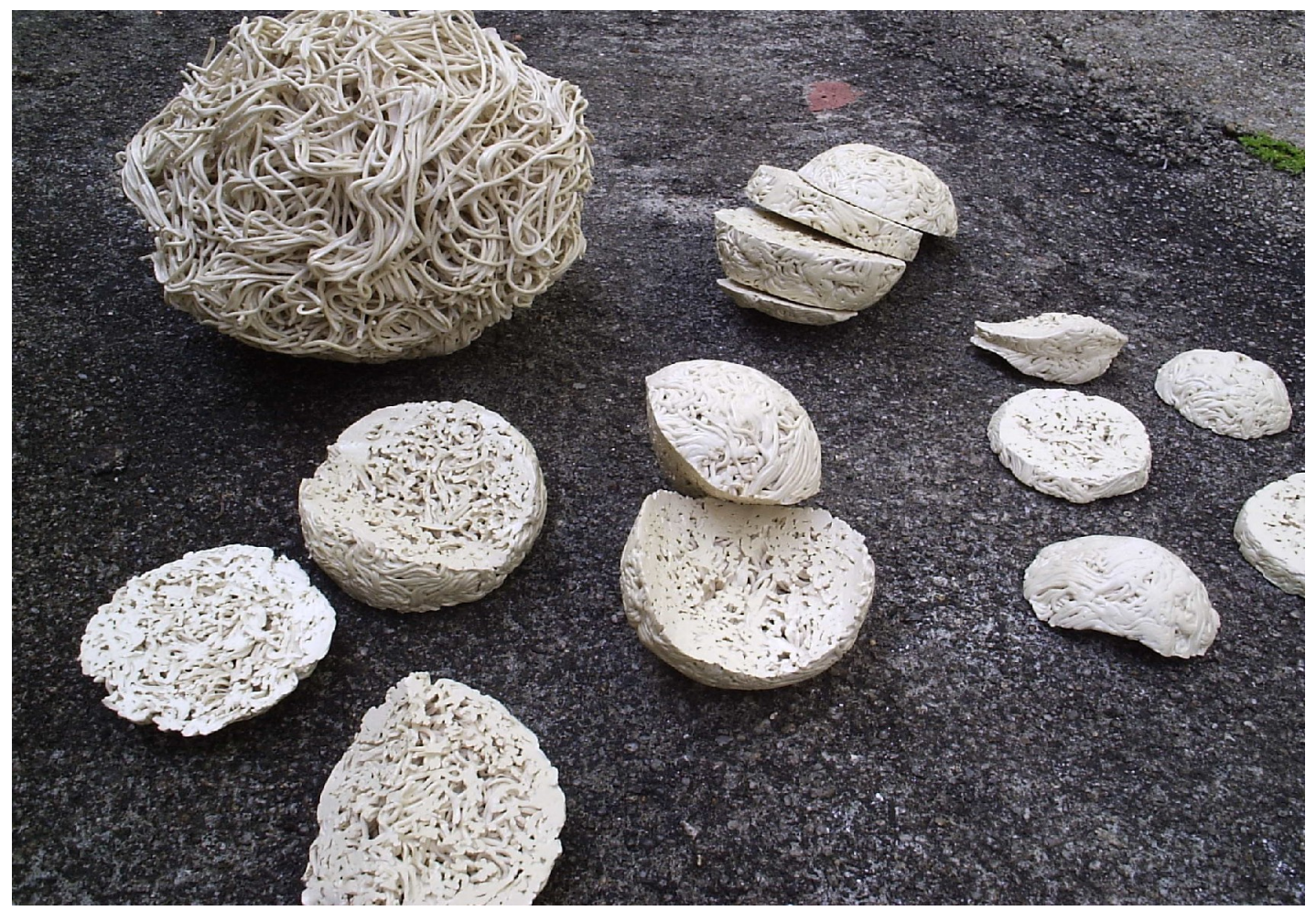

Figura 34 - Vista lateral do grupo de objetos de cerâmica, de fios feitos por compressor manual. Fonte: A autora (2005).

O próprio desenrolar do processo impôs um contato estreito com os limites do material, com uma tensão contida nas estruturas fragilmente criadas, e inclusive com nosso próprio limite para lidar com esta fragilidade, com as rupturas, os fragmentos e as reconstruções intermináveis. Muitos fios se romperam. Passou-se, então, a usar estas partes desconectadas para compor outro todo inesperado, o que exigia muita paciência e perseverança por tratar-se de uma remontagem sem fim em busca de novos resultados. É sempre bom lembrar que na cerâmica, a exemplo da natureza, também é possível que nada se perca, tudo pode ser transformado.

Os trabalhos foram queimados, em sua maioria, em forno elétrico a $1150^{\circ} \mathrm{C}$. Apenas a grande placa cindida e os fragmentos de ramas de coqueiro recobertas de barbotina, unidos por fio de náilon posteriormente a queima, foram queimados a gás a $1200^{\circ} \mathrm{C}$.

A série das caixinhas, construídas a partir dos muitos fragmentos a que se referiu anteriormente, têm colado em sua parede de fundo, fragmentos geométricos de espelhos. Neste caso interessam as imagens captadas para dentro dos objetos, 
fazendo-os mutantes, quando dinâmicos em sua transformação pela presença do reflexo do entorno e do olhar de quem com eles se relaciona.

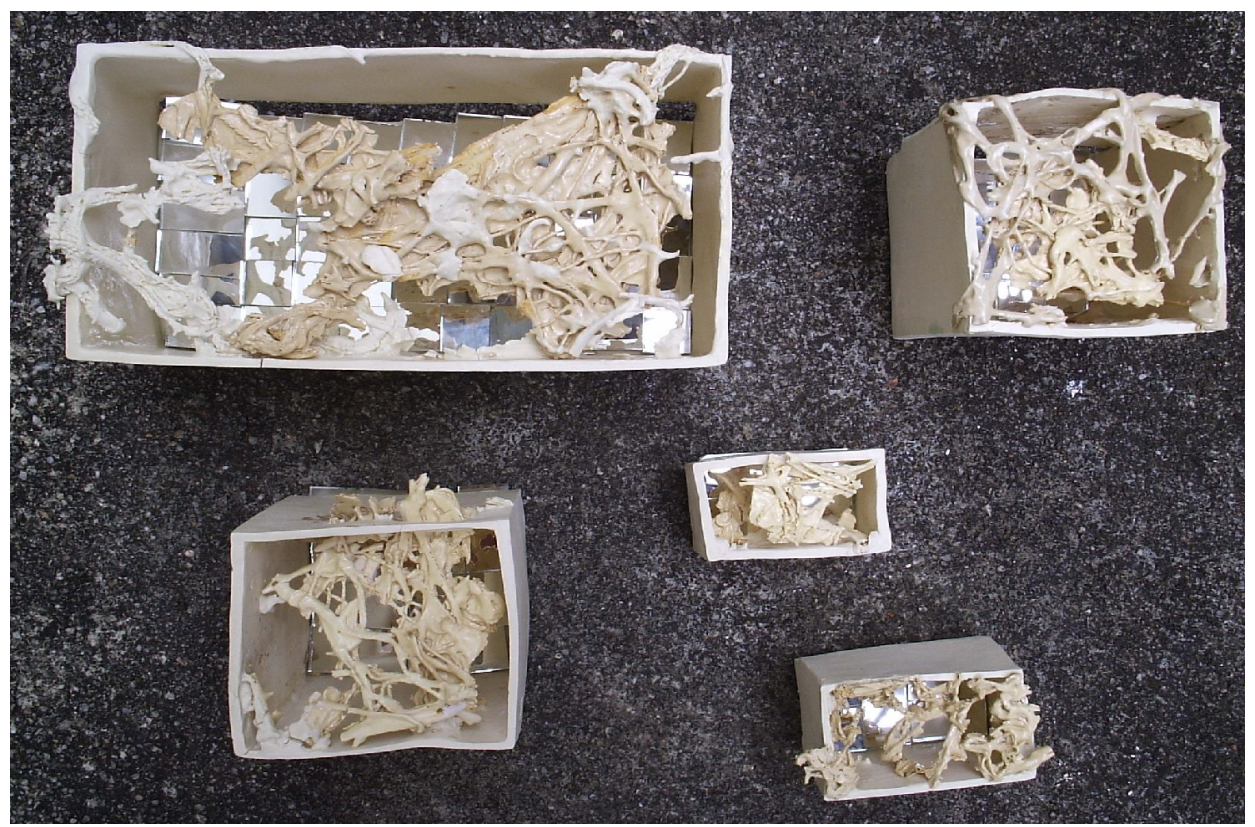

Figura 35 - fragmentos de cerâmica reaproveitados em caixas feitas com barbotina em placas de gesso. Fragmentos geométricos de espelhos. Betânia Silveira, São Paulo, 2004.

Dimensões: $11 \mathrm{~cm} \times 21 \mathrm{~cm} \times 10 \mathrm{~cm}$ (obj. maior); $3,5 \mathrm{~cm} \times 7 \mathrm{~cm} \times 3 \mathrm{~cm}$ (menor).

Fonte: A autora (2005).

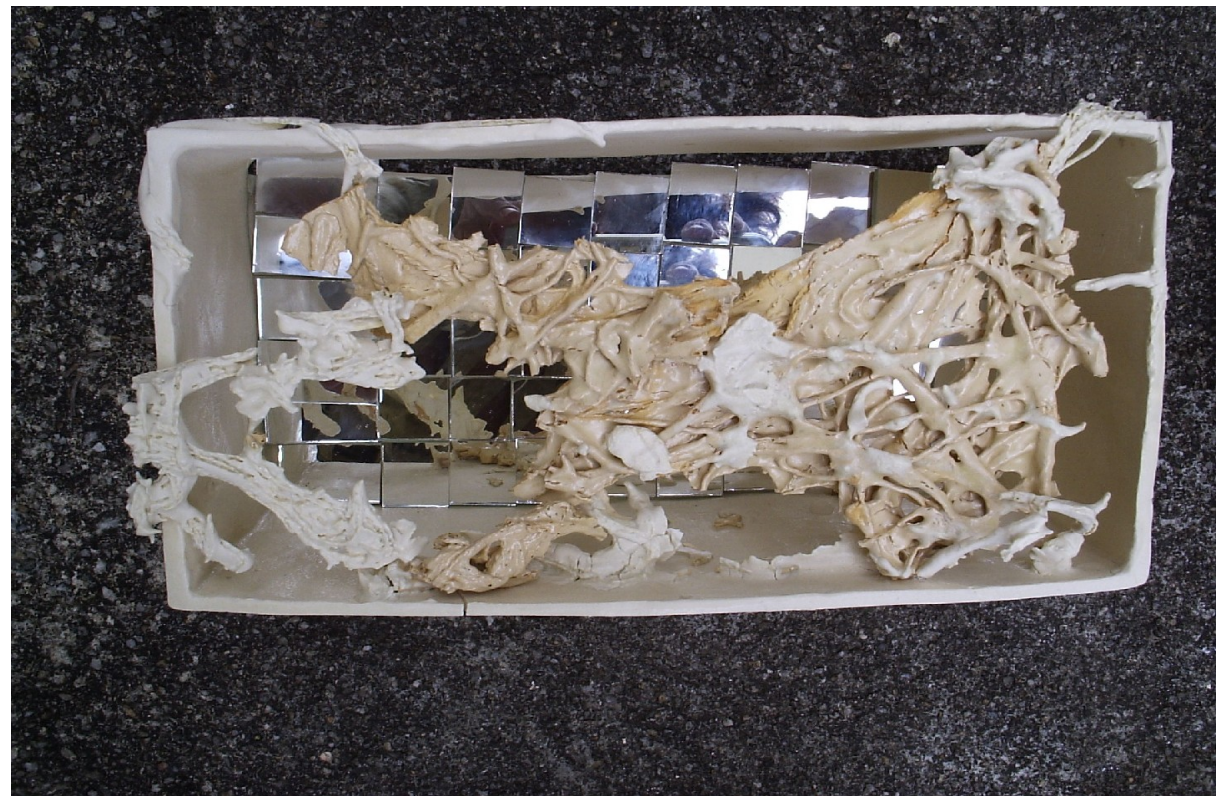

Figura 36 - Detalhe caixas feitas com barbotina em placas de gesso. Fragmentos geométricos de espelhos. Betânia Silveira, São Paulo, 2004.

Fonte: A autora (2005). 
Todos os trabalhos receberam cobertura de esmaltes mates (semitransparente $1752 \mathrm{e}$ mate creme 015, da Ferroenamel), para manter as cores claras da argila e as peças serem acrescidas de uma maior resistência sem, contudo, adicionar-lhes brilho excessivo.

As cerâmicas/tramas desenvolvidas com fios de barro assim como alguns outros trabalhos de fases anteriores passam a ser imagens digitais integrando $\circ C D$, objeto final desta dissertação. Através destas imagens deu-se ao $C D$ sua "pele" visual, onde vão estar as sinapses próprias da linguagem hipermidiática, além da poética da transformação da matéria.

Dos registros, captados por filmadora digital, da pesquisa desenvolvida em ateliê, montou-se um vídeo do processo, do qual, também, se retirou pequeninos trechos para compor cenas ainda menores e ilustrar a poética da repetição do gesto criador ao "tecer o barro". 

A CONSTRUÇÃO DO CD COMO ENTRETECIDO DE POÉTICA E INFORMAÇÃO. 
Escrever a água da palavra mar o vôo da palavra ave o rio da palavra margem o olho da palavra imagem o oco da palavra nada. (MARIA ESTHER MACIEL)

Este trabalho se realiza na construção de uma rede tramada com a poética da terra, dos devaneios da matéria, da massa e do fogo, do laborioso jogo do fazer com as mãos, com a poética do virtual, da extensão do corpo, do caminho labiríntico que se desdobra em muitas possibilidades no instante de um clicar eletrônico.

Os fios que conduzem este entretecido de cerâmica e hipermídia dizem respeito ao caráter técnico e a dimensão expressiva deste material. Portanto, ao longo deste $C D$, as imagens poéticas estão entrelaçadas às informações e ao conhecimento científico sobre o assunto.

Constitui-se da mestiçagem de duas linguagens, uma contaminando a outra. A cerâmica tão material, tão objetual e gestual, neste trabalho torna-se etérea, imaterial, fluida, digital, virtual. Como assunto e fonte originária de imagens poéticas e informativas, vai penetrar a hipermídia cuja linguagem tem seus códigos tão próprios, em essência numéricos e, portanto, abstratos, imateriais, virtuais.

Neste diálogo, nesta possibilidade intercambial da linguagem de um meio deixar-se contaminar pela de outro, encontra-se o caminho através do qual se pode percorrer este $C D$, nele a cerâmica liberta-se de sua condição material e conquista o espaço imaterial que as novas tecnologias descobriram.

Segundo Salles (1998:28), todo processo criador segue uma tendência, que não apresenta em si mesma a resolução do problema, mas indica uma direção como se, embora através de uma bruma, soubéssemos o rumo a seguir. Assim foi se formando o $C D$, aos poucos, sob uma bruma constante porém tênue, que a nós nos permitia seguir o caminho. 


\begin{abstract}
"O artista não inicia nenhuma obra com uma compreensão infalível de seus processos. Se o projeto fosse absolutamente explícito e claro ou se houvesse uma pré-determinação, não haveria espaço para desenvolvimento, crescimento e vida, a criação seria assim, um processo puramente mecânico. Há sim uma sensação de aventura (...) A ação da mão do artista vai revelando esse projeto em construção. As tendências poéticas vão se definindo ao longo do percurso: são leis em estado de construção e transformação". (SALLES, 1998, p.39-40).
\end{abstract}

É certo que o norte deste trabalho está nos nossos princípios estéticos e éticos que, apesar de estarem passando por um momento de revisão e reflexão profundas, possuem uma raiz fortemente arraigada no desejo de expansão da arte e do conhecimento, revitalizados e explicitados nesta construção híbrida de cerâmica e hipermídia, de informação e poesia.

Como na metáfora do rizoma, sentido que se dá a este trabalho, o CD-ROM "TECER O BARRO" apresenta-se como os bulbos e os tubérculos, que possuem capacidade de se expandir ou de se regenerar através da geração de novas ramificações e manifestações do seu ser. Como objeto que se realiza por inteiro quando acessado pelos hiperleitores, colabora para novas produções intelectuais, poéticas e visuais corporificadas em objetos cerâmicos, conseqüentes desdobramentos deste TECER o BARRO. Portanto, fica claro que é nesta ação que o produto $C D$, poeticamente, se concretiza por completo.

Há que se considerar da mesma forma relevante seu caráter multidisciplinar, pois seu contexto exige a participação de outros profissionais que fazendo parte do conteúdo e de sua própria criação terão seus olhares e suas marcas também impressas no processo e seu resultado.

\title{
5.1 - PROPÓSITOS E CONTEÚDO.
}


Para se materializar a cerâmica é fundamental um pedaço de argila que sempre se constituirá de uma forma, e que em estado de ponto de osso ${ }^{11}$, possa ser submetido a algum tipo de processo onde transformações físico-químicas alteram sua condição reversível à argila para um outro material que, inversamente, não só resiste ao tempo, mas também às intempéries. Dentro de um conceito científico, a argila vulgarmente conhecida por barro, para ser cerâmica, necessita passar por um tipo de calor, queima ou mesmo ser adicionada com cargas que contribuem para seu endurecimento quando secas. Sendo assim, na contemporaneidade o conceito de cerâmica se amplia. Considera-se que outros tipos de processos são capazes de provocar, de outra maneira, transformações tão contundentes na argila quanto aquelas provocadas pelo calor das queimas. Sob este ponto de vista, são cerâmicas também o ninho do João de Barro, as construções em taipas ${ }^{12}$, assim como entre outros procedimentos, as pastas auto fraguantes ${ }^{13}$, já que segundo consta no Anuário da Associação Brasileira de Cerâmica (2004, p.20), o cimento e o vidro, da mesma forma, são considerados materiais cerâmicos. Este posicionamento não é regra geral para todos os países. Portanto, há controvérsias.

Para abordar o conceito de cerâmica solicitou-se aos profissionais, nas entrevistas registradas em vídeos, seu depoimento sobre o que pensam a este respeito. Nota-se que as posturas são bem variadas e, portanto, pretende-se incitar e fomentar debates para ampliar conhecimento.

Como informação básica e primordial se deu a conhecer a composição da argila, e seus tipos, o que são as pastas ou massas, seus materiais, e como manipulá-las.

Como se considerou que as queimas são formas enriquecedoras da possibilidade de se chegar ao material cerâmico, apresenta-se algumas delas e faz-se referência a outras.

\footnotetext{
${ }^{11}$ Argila totalmente seca, livre de toda a água de mistura mecânica que constitui uma massa plástica, ou seja, que guarda em seu corpo apenas a água da umidade do ar e aquela que é elemento molecular de sua composição química. Ponto adequado à queima.

${ }_{12}$ Sistema construtivo usado na execução de paredes e muros que emprega como material de construção básico a terra argilosa, umedecida ou molhada, sem nenhum beneficiamento anterior. Materiais como areia, cascalho e fibras,entre outros, podem ser adicionados a argila, para dar-lhe maior resistência (Albernaz, M. P.e Lima, M. C. M. Dicionário llustrado De Arquitetura, 2000: 582;587;588).

${ }_{13}$ Pastas cuja composição é formada de argila, areia e cimento. Não necessitam de queima, embora possam também ser queimadas.
} 
Outra questão que se aborda como elemento de vastidão deste universo é o fato da cerâmica poder se constituir como suporte para tão diversas aplicações e manifestações. Mais uma vez, através da apresentação de vários vídeos, mostra-se desde os tipos de queimas realizadas em uma indústria semi-artesanal, onde a presença humana é decisiva, até como realizam seus trabalhos, profissionais que com a cerâmica transitam pelo espaço da arte e, mesmo, do artesanato. Alguns deles estão comentando sua poética e imagens de muitos trabalhos são mostradas, outros se apresentam demonstrando sua técnica.

Com a abordagem da técnica do torno em Santa Catarina, pretende-se divulgar uma tradição no Estado, e resgatar a memória de uma oleira, D. Zeni Josefa de Souza, primeira mulher nesta região a quebrar os paradigmas que determinavam o torno como prática estritamente masculina. D. Zeni não foi apenas produtora, mas também ensinou o ofício que antes era passado de pai para filho, questionando e subvertendo mais uma vez papéis e funções pré-estabelecidos para homens e mulheres.

Técnicas básicas e essenciais do fazer, da modelagem e construção de formas com a argila, através de uma espécie de balé das mãos, registrado em vídeos, são veiculadas ao longo deste labirinto não hierárquico do conhecimento sobre a cerâmica. Não nos interessa, neste caso, o produto formal finalizado, o resultado objetual, mais vale demonstrar os procedimentos que de forma simples podem vir, em diferentes mãos, resultar em formas complexas. Estes vídeos, além de funcionarem como imagens plenas de informações técnicas, expõem o componente poético das ações repetitivas próprias do universo da artesania do fazer. Pois como define Valèry, a poética compreende,

(...) de um lado, o estudo da invenção e da composição, o papel do acaso, aquele da reflexão, aquele da imitação; aquele da cultura e do meio; de outro lado, o exame e análise das técnicas, procedimentos, instrumentos, materiais, meios e apoios de ação. (VALÈRY apud PASSÉRON, 1975, p. 4). 
Pretende-se que a compreensão de como fazer seja acessível a qualquer pessoa, por isso escolheu-se para a realização das técnicas de modelagem, construir formas simples que encerrem todas as necessidades e ações técnicas primordiais. Com o mesmo objetivo de democratizar a compreensão do conteúdo apresentado, os textos foram escritos para serem objetivos e concisos, e as imagens escolhidas para comunicar de forma poética. Entende-se que com todas estas características tramadas seja possível a realização de uma navegação prazerosa no $C D$.

Inicialmente, logo após a abertura do $C D$, encontra-se uma página com três links. Nela há um texto, intitulado "Aos olhos de Anita Koneski"14, que faz a apresentação do meu trabalho, focando uma parte da minha trajetória como ceramista. Paralelamente, se encontra outro link com o nome, Betânia Silveira, que torna possível acessar um portifólio com imagens de alguns trabalhos plásticos desenvolvidos ao longo da minha trajetória como artista, imagens que também são usadas para ilustrar as páginas do $C D$ e dar a ele sua aparência e cores. A terceira possibilidade desta mesma página é um outro texto no qual se aborda a pesquisa plástica desenvolvida com a cerâmica, no ano de 2004, período do mestrado no qual cursava as disciplina obrigatórias, cujo objetivo principal foi desenvolver o conceito da trama no material cerâmico. Com as imagens produzidas a partir destes objetos criou-se a rede que pode ser encontrada em todas as páginas do $C D$ para facilitar ao hiperleitor transitar entre os três tópicos básicos e, da mesma maneira, conectar o mapa do DVD, um glossário básico e uma bibliografia indicada. Neste mesmo texto se apresenta o CD-ROM oferecendo acesso a todos os outros textos que compõe suas informações técnicas, suas imagens estáticas e em movimento.

O universo de conhecimento técnico da cerâmica, suas possibilidades aplicativas, poéticas entre outras, é imenso e variável. Isto implica em dizer que muitos são os percursos e conexões da cerâmica no "Tecer o Barro". O nosso trabalho poético segue

\footnotetext{
14 Anita Prado Koneski, Professora Dra do Centro de Artes da Universidade do Estado de Santa Catarina, em Florianópolis.

É nosso o título dado ao texto escrito pela Professora Anita para apresentar a autora desta dissertação. $\mathrm{O}$ mesmo pode ser encontrado em anexo.
} 
apenas uma destas possibilidades, outros profissionais, através de depoimentos e seus trabalhos plásticos, fazem parte deste desenvolvimento e entretecidos com o conteúdo informativo que aqui se encontra, abrem este leque de possibilidades. Portanto, este terceiro texto funciona como a "porta do labirinto" que dá acesso a três index que se subdividem em três temas e seus vários textos que se complementam:

- - A argila;

- -A composição das massas;

- -A queima. Neste tópico podem-se encontrar referências a outros tipos de endurecimento da argila.

Segue abaixo o mapeamento de todos os arquivos textos que compõe o $C D$, nomeados da maneira como são encontrados no html:

\section{1 index (Da argila a ceramica)}

1a Argila_Um_Conceito

1b Ceramica_Um_Conceito

1c O_Surgimento_Da_Ceramica

1d Da_Concepcao_Da_Materia

1e Constituicao_Do_Planeta_Terra

1f Classificacao_Das_Argilas_Quanto_A_Sua_Formacao

1g Classificacao_Das_Argilas_Quanto_Aos_Seus_Componentes_Minerais

1h Da_Cristalizacao_Da_Materia_E_Suas_Relacoes

\section{2 index (Dos materiais e suas mesclas as massas ceramicas)}

2a Composicao_Das_Massas

2b Materiais_Que_As_Constituem

2c Classificacao_Segundo_Suas_Temperaturas_De_Queima

2d Materiais_Antiplasticos

2d1 Refratarios

2d2 Fundentes

2d3 Estruturantes

2d4 Texturizantes

2e Quadro_Esquematico_Sobre_Massas 
2f Os_Materiais_Plasticos

2f 1 Plasticidade

2f 2 Porosidade

2f 3 Encolhimento

$2 \mathrm{~g}$ Os_Materiais_Colorantes

2h Toxidez_Dos_Materiais

3 index (Dos processos de queima a transformacao irreversivel da materia)

3a Queima

3b Aspectos_Historicos_Da_Queima

3c Fornos

3d RAKU_Ideograma_E_Aspectos_Historicos

3e RAKU_O_Processo

3f Massas_Para_O_RAKU

$3 \mathrm{~g}$ Esmaltes_Para_O_RAKU

3h Primeira_Queima

3i Segunda_Queima

3j Terceira_Queima

3k Processo_De_Secagem

3l Outros_Processos_De_endurecimento_Da_Argila

3m Forno_A_Lenha

3n A_Fogueira

3o Queima_De_Buraco

3p Queimas_Com_Serragem

Ao longo destes tópicos, encontram-se os vídeos de técnicas de modelagem, alguns tipos de queimas e depoimentos.

Com o objetivo de ampliar o conhecimento sobre a cerâmica e seu fazer, através da conexão ao site 'WWW.tecerobarro.multiply.com, do próprio $C D$ em questão, poder-se-á acessar outras informações, inclusive do "Manual Virtual de Cerâmica", produção desenvolvida anteriormente (Edital de Incentivo á Cultura, 2002/03/SC) que possui um 
conteúdo mais abrangente sobre o universo da cerâmica. Interligar-se-á a outros sites, para que se possam expandir as trocas entre aqueles que valorizam e se interessam pela cerâmica como arte além de tecnologia. 
CONCLUSÃO. 
Nós não somos os criadores de nossas idéias, mas apenas seus porta-vozes; são elas que nos dão forma e cada um de nós carrega a tocha que no fim do caminho outro

A cerâmica é arte e tecnologia em constante desenvolvimento. Pode associar-se às novas mídias e através delas, circular vinculada a poética digital como instrumento para propagação de técnica e poesia num só "verso". Sendo assim, utilizando-se das inúmeras possibilidades dos computadores, prova que seu fazer transcende suas raízes primevas para estar inserido no mundo da agilidade virtual.

É este espaço de significação que se inaugura através dos computadores e redes, o espaço da textualidade informática, que se ocupa com a criação deste $C D-R O M$ híbrido sobre a cerâmica. Produção esta que, não só adota o rizoma conceitualmente, mas também, efetivamente, em sua estrutura hipertextual. Aqui estão disponibilizadas imagens poéticas e diversas informações conectadas entre si e sem que se determine uma hierarquia ou um centro específico de onde se deva partir.

Como o fazem os bulbos e tubérculos em sua capacidade de se reproduzir, este $C D$ $R O M$ se constitui em um meio que promoverá novas alianças. Funcionando como o eixo de um rizoma, será sempre um entre, nunca o princípio, nem o final. Como bem coloca Deleuze e Guatarri (2000:15), “... Qualquer ponto de um rizoma pode ser conectado a qualquer outro e deve sê-lo". Neste aspecto está contida sua essência multiplicadora.

Muitas "vozes" estão presentes promovendo vivência estética, conhecimento e reflexão. Esta multiplicidade de manifestações e caminhos para se realizar a matéria e a forma, evidencia a extensão deste universo. Portanto, a realização deste $C D$ é o resultado de uma série de conecções do saber para gerar novas formulações do conhecimento e apresenta-se como um desafio já que se propõe ser um sistema aberto a uma pluralidade de discursos, onde estão contidas informações de muitas fontes diferentes, olhares diversos sobre a cerâmica e seu fazer. Desta forma, contatos de toda ordem serão realizados com os leitores que processarão infinidades de relações e que, por 
sua vez, também, não serão estáticas nem finalizadoras. Como uma obra de arte, este $C D$ estará sempre aberto a novas decantações de sentidos e estruturação de conhecimento.

Desenvolver a expressão poética e poder, paralelamente, instrumentalizar outras pessoas, via $C D$ em hipermídia, para um bom desenvolvimento de trabalhos em cerâmica, faz parte da procura de desdobrar conhecimentos e estimular ações produtivas e reflexivas.

A verdadeira integração entre a educação e a tecnologia abre novos horizontes e é a base que fundamenta a educação pós-moderna. Mas, para que essas tecnologias possam ser utilizadas para atingir objetivos pedagógicos em instituições educativas, é necessária uma estratégia de ensino-aprendizagem claramente definida, assim como a existência de alguns elementos estruturais básicos com os quais os usuários possam contar. Não cabe aqui o desenvolvimento destes rumos, mas sim poder contribuir para isto com esta produção.

Este produto final pode vir a ser usado para se conhecer alguns artistas e outros profissionais que usam a cerâmica como suporte para seus trabalhos, assim como suas produções. Da mesma forma, poderá ser utilizado por pessoas que queiram experimentar o processo do fazer em ateliês, escolas de primeiro e segundo graus e, inclusive, nas universidades, considerando que em seu conteúdo se podem encontrar níveis diversos de informação e de dificuldade.

O computador funciona como uma extensão da memória e organiza o trabalho mental, com ele economiza-se o trabalho oral, por conseguinte, essa produção pode funcionar como material de pesquisa e recursos pedagógicos para professores e até mesmo, com justa adaptação, aos ambientes virtuais de aprendizagem, fazendo parte dos recursos materiais adequados a esta nova modalidade de ensino, constituindo-se em uma nova conexão para multiplicar e desdobrar conhecimento. 
As telas que apresentam o conteúdo propiciam ao leitor ir e vir em sua navegação e pesquisar o que lhe convém, percorrendo o caminho que melhor the aprouver, além de permitir-Ihe também a impressão de textos e o enriquecimento do glossário que poderá ser copiado para um outro arquivo e assim, ser acrescido de outros termos. Da mesma maneira, nelas se encontram indicações para outros sites e comunidades virtuais envolvidos com o tema da cerâmica.

Além da preocupação estética com seu formato, que abriga nossa expressão poética e de outras manifestações expressivas, de sua também dimensão educacional, informacional, de referencial teórico e técnico, esse material contempla um caráter jornalístico e documentário, uma vez que entrevista os profissionais, indústrias e instituições envolvidos com a cerâmica, em diferentes aspectos.

A cerâmica como expressão, seus produtos e processos, assim como a discussão de questões reflexivas sobre seu fazer podem estar ligados à rapidez, à inventividade, à multiplicidade e à interatividade, próprias do mundo virtual.

Esta não pretende ser uma obra finalizada. Mais do que definir e estabelecer conceitos fechados pretende-se ampliá-los, mobilizando reflexões e debates, pois como diz Borges (apud Machado, 1997): "o conceito de texto definitivo não corresponde senão à religião ou ao cansaço". 
REFERÊNCIAS 
ALBERNAZ, M. P. e LIMA, M. C. M. Dicionário ilustrado de arquitetura. Editor Vicente Wissenbach. 2ª edição São Paulo: Pro Editores, 2000.

ALMEIDA, Efigênia Soares. O pólo cerâmico do vale do rio Tijuca, 1992. 107 p. Dissertação (Mestrado em geologia) UFSC. Florianópolis, SC.

ALMEIDA, E. S.; BORGES, S. F. Programa de treinamento de professores em geociências e meio ambiente. Universidade do Vale do Itajaí. Itajaí, SC, 1997.

ANUÁRIO da Associação Brasileira de Cerâmica. [S.I.: s.n.] 2004, p.20.

ARCHER, Michael. Arte contemporânea: uma história concisa. Tradução Alexandre Krug, Valter Lellis Siqueira. S Paulo: Martins Fontes, 2001. Título original: Art Since 1960- (Coleção a).

BACHELARD, Gaston. A terra e os devaneios da vontade: ensaio sobre a relação das forças. São Paulo: Martins Fontes, 1991.

. A poética do espaço. São Paulo : Martins Fontes, 1993.

BIRKS, Tony. The complete potter's companion. Hong Kong: Bullfinch, 1996. 5v reestruturada.

BRAGA, Nicia. Apostila curso especial de cerâmica:1990/1991. Belo Horizonte: [s.n.], 1990.

BUITONI, Dulcília H. S. Entre o consumo rápido e a permanência: jornalismo de arte e cultura In: Martins, Maria Helena (Org). Outras leituras: literatura, televisão, jornalismo de arte e cultura, linguagem interagente. São Paulo: Itaú Cultural, 2000. p.55 - 72

CALDAS, Alberto Lins. Do texto ao hipertexto - da leitura à hipertextualidade. Disponível em: <iwww.unir.br/ primeira/artigo22.htmi >. Acesso em: 13 set. 2003.

Cerâmica britânica. Tradução. Stella Meyr, Caetana Brito.( S.I. ): Council British Museum, 2000. p.86. Título original: Firing imagination.

CHAVARRIA, Joaquim B. A cerâmica. Trad. Rui Pires Cabral. Lisboa: Estampa, 1997. Título original: La cerâmica.

CHARBONNIER, Georges. Arte, linguagem, etnologia: entrevista com Claude LeviStrauss. Campinas: Papirus, 1989.

CHITTI, Fernandez Jorge. Curso Practico de ceramica. Buenos Aires: Condorhuasi, [19-]. $4 \mathrm{v}$.

El libro del ceramista. Buenos Aires: Condorhuasi, [19--].

Manual de esmaltes cerâmicos. Buenos Aires:Taller Condorhuasi, [19--]. 
COSENTINO, Peter. Alfareria creativa. Barcelona :Hermann Blume, 1988.

COOPER, Emmanuel. Historia de la cerâmica. Barcelona: Ceac, 1987.

COSTA, Marcus de Lontra (Cur.). Arte do fogo, do sal e da paixão: Celeida Tostes. Rio de Janeiro: Fund.Cultural Banco do Brasil, 2003. Exposição realizada no Centro Cultural Banco do Brasil, Rio de Janeiro.

DELEUZE, Gilles; GUATTARI, Félix. Mil platôs: capitalismo e esquizofrenia, São Paulo: Ed. 34, 2000.

DAVID, Madeleine. Cerâmicas e porcelanas chinesas. São Paulo: Martins Fontes,1991.

DOMINGUES, Diana. Criação e interatividade em ciberarte. São Paulo: Experimento, 2002.

EDITORIAL37. Disponível em: <'http://7mares.terravista.pt/apecv/Ëditoriā37.htm's Acesso em: 22 abr. 2004.

FARACO, Emílio Carlos e DE MOURA, Francisco Marto.Gramática. São Paulo,Ed: Ática, 1989. 3.ed.

FERRO, Jorge E. Moreno. Proposta de ambiente virtual colaborativo/cooperativo para atualização e capacitação de designers no desenvolvimento de novos produtos para o setor de revestimento cerâmico. 2003157 p. Dissertação ( Mestrado em Engenharia de Produção), Universidade Federal de Santa Catarina, Florianópolis.

FLIGTH, Graham. Introduction to ceramics. Toronto: Prentice Hall, 1991.

GABBAI, Myrian. Cerâmica, Arte da terra. São Paulo: Callis, 1987.

GOMES, Julio. Ceramica raku (4 parte): pastas. Nueva Ceramica e Vidrio, Buenos Aires, anõ 2, n. 8, p. 38-39, verano1997.

Cerâmica raku (5 parte): esmaltes. Nueva Cerâmica e Vidrio, Buenos Aires, ano 3, n. 9, p. 24-25, inverno1997.

Cerâmica raku (6 parte): esmaltes II. Nueva Cerâmica e Vidrio, Buenos Aires, ano 3, n. 10, p. 42-43, primavera1997.

GUEVARA, Roberto (Cur.). II Bienal do Barro de América 1995 - 1996: encuentros contemporáneos: núcleo1: Museo de Arte Contemporáneo de Caracas Sofia Imber. Caracas: Consejo Nacional de la Cultura, 1995.

GRINBERG, Norma T. Humanóides: transmutações da forma e da matéria, 1994. 78 p. Dissertação (Mestrado em Poéticas Visuais) Escola de Comunicações e Artes da Universidade de São Paulo. São Paulo, SP. 
INSTITUTO ANTÔNIO HOUAISS. Dicionário eletrônico da língua portuguesa. Rio de Janeiro: Objetiva, 2002. 1 CD-ROM. Windows 98.

JOHNSON, Steven. Cultura da interface: como o computador transforma nossa maneira de criar e comunicar, tradução. Maria Luísa X.de Borge. Revisão Técnica Paulo Vaz. Rio de Janeiro: Jorge Zahar, 2001.

KENNY, John B. The Complet book of pottery making. 2. ed. rev. e ampl. Pennsylvania: Chilton Book Company, 1976.

KITTO, Lucy; et.all. The japanese pottery hand book._London: Kodansha,1979

LAGE, Otacílio. Minas domina os bioativos. O Estado de Minas, Belo Horizonte, 05 jan. 2003.

LEACH, Bernard. Manual del ceramista. Barcelona: Blume, 1981.

LEÃO, Lucia; A estética do labirinto. São Paulo: [s.n.], 2002.

A Complexidade da hipermídia In O LABIRINTO da hipermídia. São Paulo: Ed. Iluminuras, 1999. p. 55-77

O Labirinto e a arquitetura do ciberespaço In: NOJOSA, U. GARCIA, W. (Org.). Comunicação e tecnologia. São Paulo: Nojosa, 2003. p. 153 - 167.

LEINZ, Victor. Geologia geral. São. Paulo: Ed Nacional. 1980.

LEITE, Ligia Silva e SILVA, Christina Marília Teixeira. A sociedade conectada: caminhos para a formação de professores. Conect@ vol. 3; novembro 2000. Disponível em "http://www.revistaconecta.com/conectados/ligia conectada.htm. Acesso em: 15 julho 2004 .

LEVI-STRAUSS, Claude. A oleira ciumenta. São Paulo: Brasiliense, 1985.

LÉVY, Pierre. Cibercultura. São Paulo: Ed.34, 1999.

A Conexão planetária: O mercado, o ciberespaço, a consciência e o mundo entrelaçados. São Paulo: Ed 34, 2001.

MACHADO, Arlindo. Hipermídia: o labirinto como metáfora. In: DOMINGUES, Diana. (Org.). A arte no século XXI: a humanização das tecnologias. São Paulo: UNESP, 1997. p. $144-154$.

MACHADO, Irene. Redescoberta do sensorium In: Martins, Maria Helena (Org) Outras leituras: literatura, televisão, jornalismo de arte e cultura, linguagem interagente. São Paulo: Itaú Cultural, 2000. p. 73 - 94. 
MENÇA, Luiz. Quema con un horno de papel. Nueva Cerâmica e Vidrio, buenos Aires, ano 5, n. 17, p. 18-19, otonõ 2000.

MURRAY, Janet H. Holodeck, O futuro da narrativa no ciberespaço. São Paulo: Itaú Cultura, 2003.

NAKANO, Katsuko. Terra, fogo, homem. São Paulo: Aliança Cultural Brasil-Japão, 1989.

NEGROPONTE, Nicholas. A vida digital. São Paulo: Cia das Letras, 1995.

OSTROWER, Fayga. Criatividade e processos de criação. 2.ed. Petrópolis: Vozes, 1987.

PAREYSON, Luigi. Estética: Teoria da Formatividade. Petrópolis: Vozes, 1993.

PASCHOALIN, Maria Aparecida. Gramática: teoria e exercícios / Paschoalin e Spadoto. São Paulo: FTD, 1989.

PLAZA, Júlio; TAVARES, Mônica. Processos criativos com meios eletrônicos: meios digitais. São Paulo: Ed Hucitec, 1998. p.119 - 185.

PONTY, M. Merleau. O Entrelaçamento: o quiasma. In: O visível e o invisível. São Paulo: Perspectiva, 1992. p.127 - 150.

RHODES, Daniel. Clay and glazes for the potter. Pensilvania: Chilton Book, 1972.

RODRIGUES, Maria Regina. Passagem pela passagem: semiotização da obra de Celeida Tostes. 1998. 111 p.. Dissertação (Mestrado em Comunicação e Semiótica), Pontifícia Universidade Católica de São Paulo, SP.

RODRIGUES, Bruno. Webwriting: pensando o texto para a mídia digital. São Paulo: Berkeley Brasil, 2000.

RODRIGUES, Sérgio Kleinfelder. Nossa terra nossa casa. São Paulo: DNPM/CPRM, 1985.

SANTA CATARINA. Edital estadual de apoio a cultura. Ano 2002. Fundação catarinense de Cultura. Florianópolis, SC.

SALLES, Cecília Almeida. Gesto inacabado: processo de criação artística. São Paulo: FAPESP, 1998.

SANTAELLA, Lúcia. Teoria geral dos signos. 2. ed.rev. ampl. São Paulo: Ed Pioneira, 2000.

SANTOS, Pérsio de Souza. Ciência e tecnologia das argilas. São Paulo: Edgard Blucher, 1989. 
SCHREIBER, Sheley. A Noborigama in the Colorado mountains. Ceramics Mounthly, Westerville, v. 45, n. 9, p.41-46, nov. 1997.

SEVERINO, Antônio Joaquim. Metodologia do trabalho científico. .ed. rev. e ampl. São Paulo: Cortez, 2002.

SILVEIRA, Maria B. Na cerâmica fala a natureza: da concepção da matéria às imagens realizadas. Passo Fundo (Rio Grande do Sul): Universidade de Passo Fundo, 1996. Monografia de Especialização em Cerâmica.

STUBBS, Carol. Piyro mania 99. Clay Times, Waterford, v. 5, n. 4, p. 116-17, july - aug. 1999.

TAYLOR, Bárbara. Ninhos e tocas. trad. Beth Vieira. Londres: Dorling Kindersley Book. Ed. Globo S. A., 1997.

VANCE, Jack. Os oleiros de firsk. mimeo S.I.: s.n.

VARELA, Rosa Ma; BARRIUSO, Angel L; MARTIN, Antônio. Curso de cerâmica: escuela municipal de alfareria. ayuntamiento de valladolid. Espanha: Imprensa Municipal, 1993.

VENTURELLI, Suzete. Arte: espaço - tempo - imagem. Brasília: UNB, 2004.

VIRÍlIO, Paul. O espaço crítico. São Paulo: Editora 34, 1999.

VITTEL, Claude. Cerámica:pastas y vidriados. Madrid: Paraninfo, 1978.

WARSHAW, Josie. The complete practical potter: A Comprehensive Guide to Ceramics, with Step by step projects and techniques USA: Lorenz Books, 1999.

WILSON, Richard L. Inside japanese ceramics: a primer of materials, techniques, and traditions. Tokyo: Weatherhill, 1995.

WILCOX, Sue Ki. Raku ho'olaule'a: a Hawaiian gathering to celebrate raku. Clay Times, Waterford, v. 4, n. 5, p. 46-48, sep. - oct.1998. 


\begin{abstract}
ANEXOS
"Aos Olhos de Anita Koneski".

De Betânia Silveira quero falar como minha mestra ceramista. Esta que sem fazer apologias infunde em nós, seus alunos, a dimensão maior de trabalhar o barro. Desta forma, não compreendo a realização deste $C D$-ROM senão como um desejo seu de expandir as suas relações com a cerâmica em espaços onde ela não pode estar fisicamente. Realiza-o, então, neste espaço imaterial que no seu caso, gosto de ver como um espaço da alma. Este projeto é, sem dúvida, um amor expandido dessa artista plástica que aprendeu no manuseio do barro, doar-se generosamente aos que com a cerâmica buscam contato.
\end{abstract}

Mas, a mestra ceramista é uma artista plástica que transforma os materiais no esforço de renovar as leituras sobre o mundo. Os trabalhos de Betânia unem poeticamente o barro a outros materiais conquistando efeitos dicotomizantes que revelam as polaridades de nossa própria existência. Neles, o barro une-se ao metal e ao acrílico. $\mathrm{O}$ opaco se afina com o translúcido. O negativo se apóia no positivo. Um esforço para dizer que a dicotomia é inerente à totalidade do ato de habitar o mundo.

Este esforço muitas vezes dilacera o material plástico e o integra ao barro como uma acusação a um tempo necessitado de deuses. Tais trabalhos nos alertam que só vamos encontrá-los quando, nas tramas ardilosas da tecnologia, recuperarmos o humano. É do humano que Betânia nos fala quando o presentifica nos gestos sutis que poeticamente lê nas suas próprias mãos. Gestos cotidianos, retirados não de mãos que posam para o escultor, mas colhidos ali onde elas gesticulam a existência; mãos de toda a humanidade. São poetas como Betânia que nos mostram em tempos niilistas, sensibilidade para caminhos mais alentadores. 
No movimento de retirar e anexar o barro Betânia capta o potencial do resto, do resíduo, quando os reverte em obras. A mestra revela que se a ausência "fala" e dá significado a um espaço, o cheio pode resignificar o vazio, em outro. Desta forma, Betânia vai tecendo os contrários na duração do "elã vital" da existência.

Resta-nos dizer que Betânia faz potes, faz ninhos e amparo para os alimentos. Cerca com o barro o vazio e neles acolhe nossos olhares para mostrar que os vazios são cheios, tal qual as conchas do mar que, aparentemente vazias, guardam o murmúrio do lugar sagrado.

Betânia se funde com o barro pela sua generosidade. Não fragmenta o fazer artístico do gesto didático. Revela-nos, através deste $C D$-ROM um modo contemporâneo de ser um pouco mestre medieval, aquele que circulava sem preconceitos entre o fazer e o ensinar e que ensinava mesmo quando não estava presente, porque deixava sempre a alma no que fazia.

Anita Prado Koneski.

Professora Doutora do Centro de Artes da Universidade do Estado de Santa Catarina, CEARTE/UDESC. 


\section{TECER O BARRO}

\section{I - INSTRUÇÕES PARA USO DO CD:}

- Inserir adequadamente o $C D$ no driver. Permitir conteúdo ativo e bloqueado.

- Abre automaticamente em questão de segundos.

- Para visualizar em tela cheia clicar F11.

- Clicar no arquivo do $C D$ /index.htm caso não abra o automático.

- Para navegar passar com o mouse sobre a tela e clicar sobre palavras em destaques e imagens.

II - CONFIGURAÇÕES MÍNIMAS EXIGIDAS:

- Leitor de $C D$.

- Softwares java e Active X para abrir o mapa.

- Windows 98 ou posteriores.

- Para ler os vídeos, programas como, por exemplo:

Windows média ou Quick time player. 
This document was created with Win2PDF available at http://www.daneprairie.com. The unregistered version of Win2PDF is for evaluation or non-commercial use only. 